US Army Corps of Engineers ${ }_{\circledast}$

Engineer Research and

Development Center

Regional Sediment Management (RSM) Program

\title{
Analysis of Nearshore Placement of Sediments at Ogden Dunes, Indiana
}

David L. Young, Katherine E. Brutsché, Honghai Li, Brian C. McFall,

March 2020

Erin C. Maloney, Kaitlyn E. McClain, David F. Bucaro, Jessica Z. LeRoy, James J. Duncker, Kevin K. Johnson, and P. Ryan Jackson

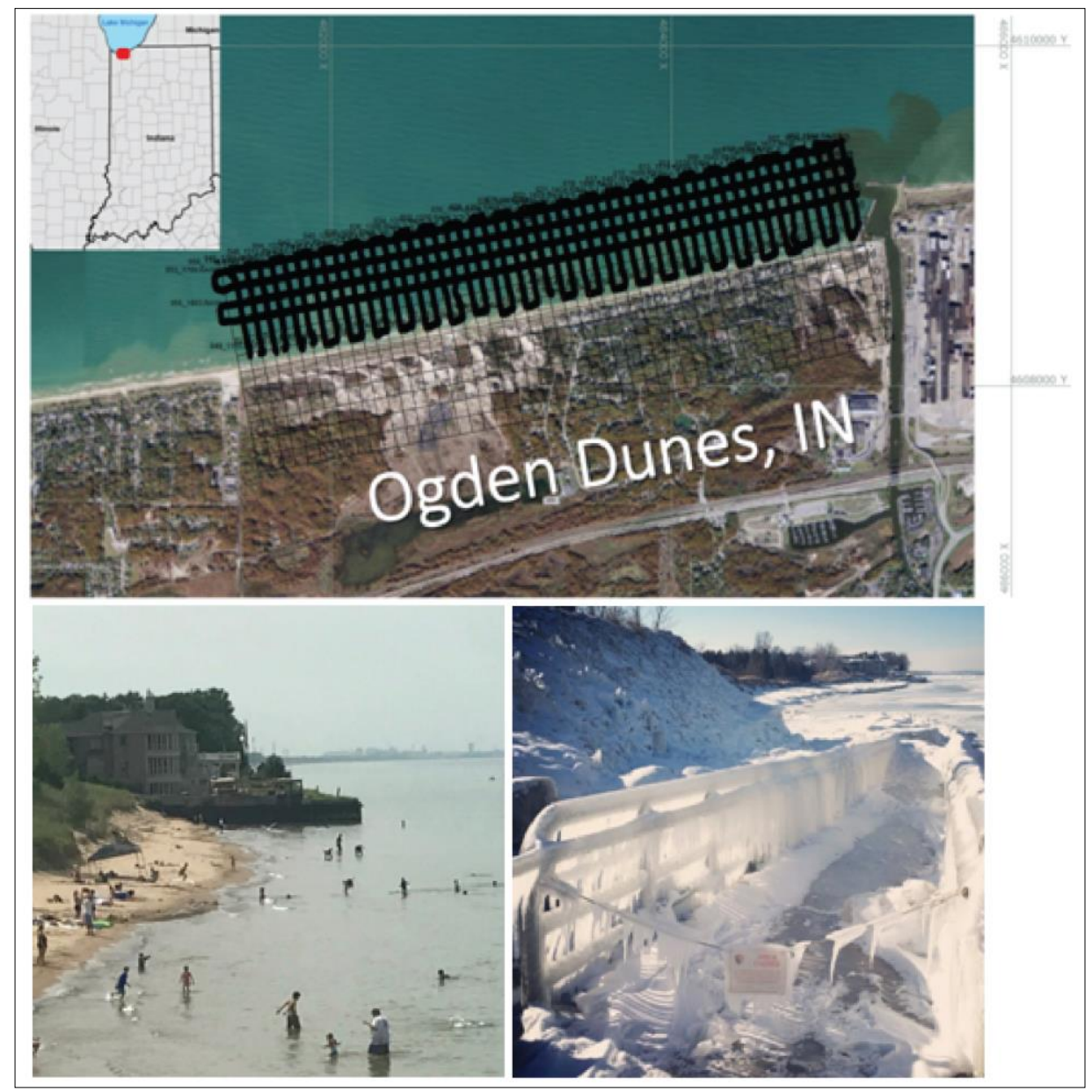


The US Army Engineer Research and Development Center (ERDC) solves the nation's toughest engineering and environmental challenges. ERDC develops innovative solutions in civil and military engineering, geospatial sciences, water resources, and environmental sciences for the Army, the Department of Defense, civilian agencies, and our nation's public good. Find out more at www.erdc.usace.army.mil.

To search for other technical reports published by ERDC, visit the ERDC online library at http://acwc.sdp.sirsi.net/client/default. 


\section{Analysis of Nearshore Placement of Sediments at Ogden Dunes, Indiana}

David L. Young, Katherine E. Brutsché, Honghai Li, Brian C. McFall

Coastal and Hydraulics Laboratory

US Army Engineer Research and Development Center

3909 Halls Ferry Rd.

Vicksburg, MS 39180-6199

Erin C. Maloney, Kaitlyn E. McClain, David F. Bucaro

US Army Corps of Engineers, Chicago District.

231 LaSalle Street, Suite 1500

Chicago, Illinois 60604

Jessica Z. LeRoy, James J. Duncker, Kevin K. Johnson, P. Ryan Jackson

US Geological Survey

Central Midwest Water Science Center

405 N. Goodwin Ave.

Urbana, Illinois 61801

Final report

Approved for public release; distribution is unlimited.

Prepared for US Army Corps of Engineers, Regional Sediment Management Program

Vicksburg, MS 39180

US Army Corps of Engineers, Chicago District

Chicago, IL 60604

Under Funding Account Code U4362913; AMSCO Code 008303 


\section{Abstract}

The harbor structures/shoreline armoring on the southern Lake Michigan shoreline interrupt sand migration. Ogden Dunes, Indiana, and the nearby Indiana Dunes National Lakeshore observed shoreline erosion due to engineered structures associated with Burns Waterway Harbor (east of Ogden Dunes) impeding natural east-to-west sediment migration. To remedy this, USACE placed over 450,000 cubic meters $\left(\mathrm{m}^{3}\right)$ of dredged material post-2006 in the nearshore of Ogden Dunes. However, the effectiveness of nearshore placements for shoreline protection and littoral nourishment is not fully established. To improve nearshore placement effectiveness, USACE monitored the June/July 2016 placement and subsequent movement of 107,000 $\mathrm{m}^{3}$ of dredged material in the nearshore region at Ogden Dunes. This involved an extensive monitoring scheme (three bathymetry surveys, and two acoustic Doppler current profiler deployments), a Coastal Modeling System (CMS) numerical model of the changes following placement, and a prediction of sediment transport direction using the Sediment Mobility Tool (SMT). The SMT-predicted sediment migration direction was compared to observations. Observations indicated that between 10/11/2016 and 11/15/2016 the centroid of the sediment above the pre-placement survey moved $17 \mathrm{~m}$ onshore. These observations agreed with SMT predictions - onshore migration under storm and typical wave conditions. CMS accurately reproduced the hydrodynamic features.

DISCLAIMER: The contents of this report are not to be used for advertising, publication, or promotional purposes. Citation of trade names does not constitute an official endorsement or approval of the use of such commercial products. All product names and trademarks cited are the property of their respective owners. The findings of this report are not to be construed as an official Department of the Army position unless so designated by other authorized documents. 


\section{Contents}

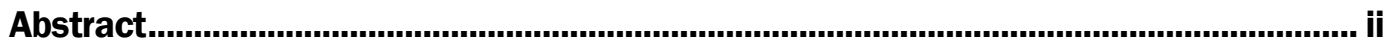

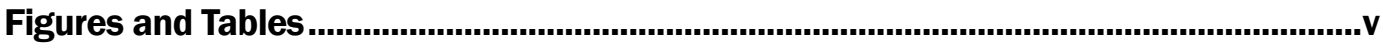

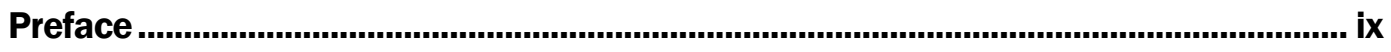

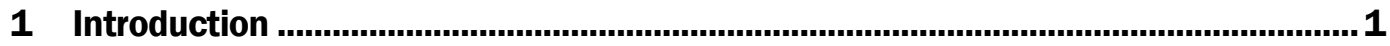

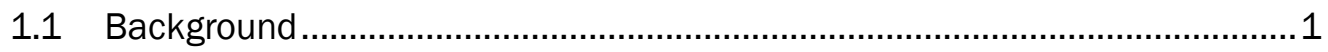

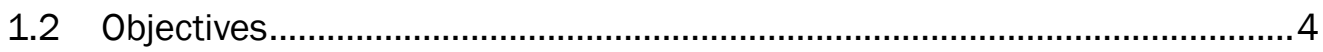

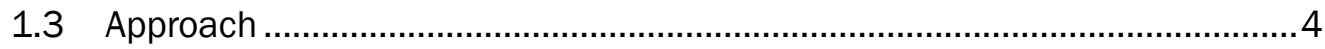

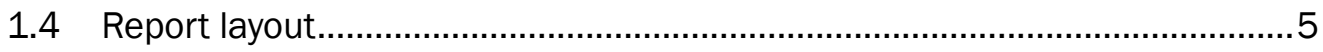

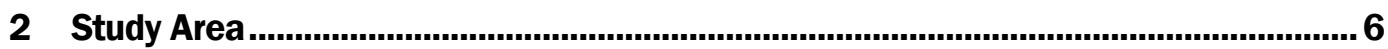

3 Dredging and Nearshore Placement at Ogden Dunes ........................................ 7

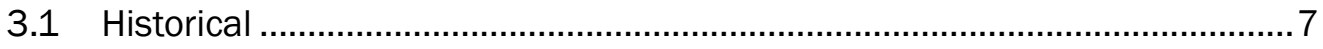

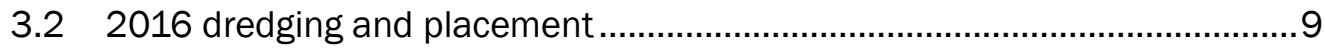

4 Sediment Mobility Tool (SMT)

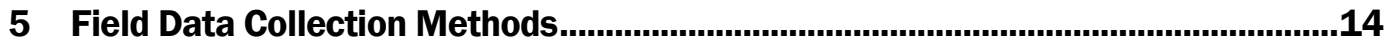

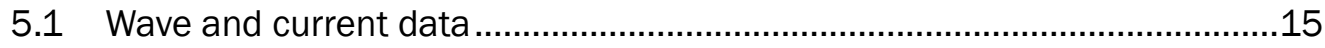

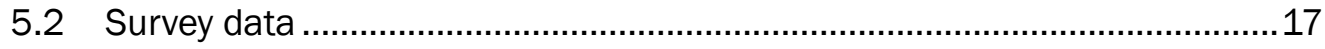

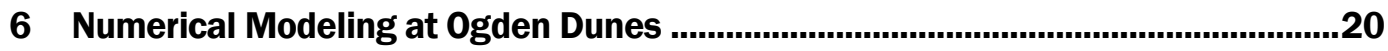

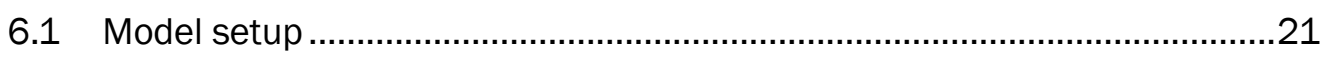

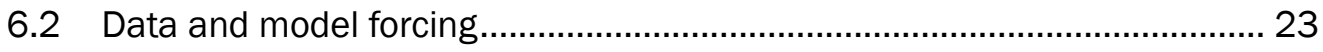

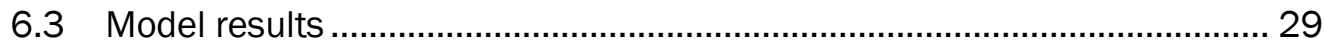

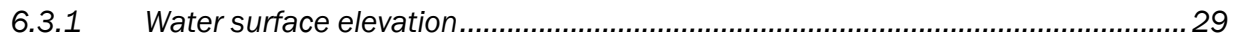

6.3.2 Currents ................................................................................................... 31

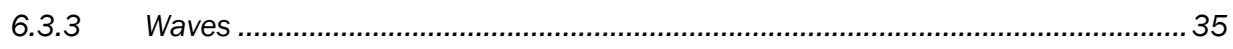

6.3.4 Sediment transport and morphology change.................................................... 38

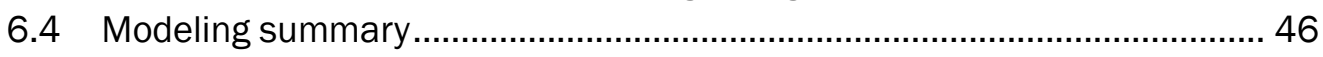

7 Morphologic Change ........................................................................................... 47

7.1 Survey data processing and Digital Elevation Model (DEM)

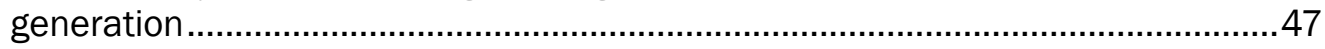

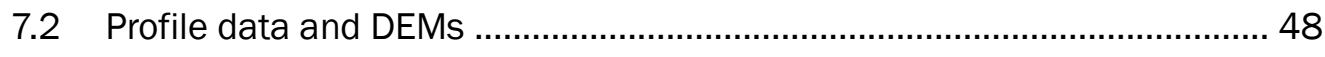

7.3 Variation in the post-placement surveys ................................................ 58

7.4 Morphology change with the 11/15/2016 profile adjustment ...................61

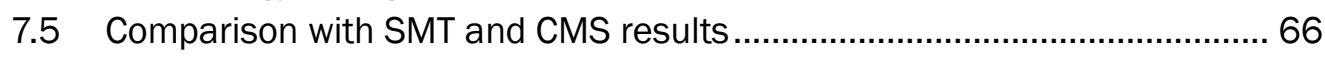




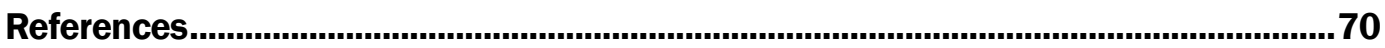

Appendix A: Grain Size Distribution Test Data ..........................................................73

Appendix B: Configuration File for ADCP Deployment................................................80

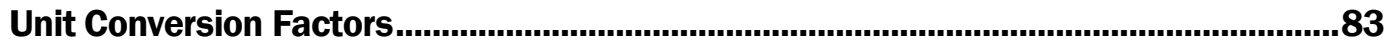

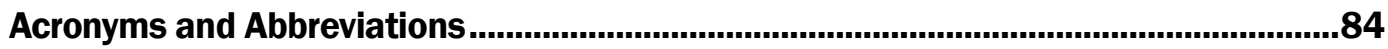

Report Documentation Page 


\section{Figures and Tables}

\section{Figures}

Figure 1. Location of the study area and nearby locations of interest.

Figure 2. Lake Michigan lake levels, including seasonal averages (1960-2018).

Figure 3. Erosion impacts on private residences and public access within the study area.

Figure 4. Nearshore placement locations near the Town of Ogden Dunes, Indiana. Adapted from Arnold et al. (2018), with permission.

Figure 5. Elevation difference between the 10/11/2016 ADCP survey digital elevation model (DEM) and the 6/2/2016, ADCP survey DEM showing the offshore mound and identifiable peaks.

Figure 6 . Histogram showing frequency of sediment mobility using linear wave theory under typical wave conditions. Reprinted from Arnold et al. (2018), with permission.

Figure 7. Histogram showing frequency of sediment mobility using non-linear wave theory under storm wave conditions. Reprinted from Arnold et al. (2018), with permission.

Figure 8. Dominant wave direction during typical wave conditions. $\mathrm{H}_{\mathrm{mo}}$ is equal to four times the standard deviation of the sea surface elevations. Reprinted from Arnold et al. (2018), with permission.

Figure 9. Dominant wave direction during storm wave conditions. Reprinted from Arnold et al. (2018), with permission.

Figure 10. Google Earth image of Lake Michigan near Ogden Dunes, Indiana. The dredge placement area is outlined by the yellow rectangle. Bathymetric survey lines are shown in black, and two upward-looking ADCPs are shown as red stars. 15

Figure 11. Upward looking ADCP and mount prior to deployment.

Figure 12. Sub-aerial beach and shallow water bathymetry surveys with the backpack-mounted Trimble Ag132 GPS.

Figure 13. Dredging barge for NIPSCO working in the study area during the 9/8/2016 bathymetry survey.

Figure 14. The CMS framework and its components (Aquaveo 2010).

Figure 15. CMS domain, CMS-Flow telescoping grid and bathymetry.

Figure 16. Non-uniform rectangular CMS-Wave grid and bathymetry. The CMS-

Flow domain is outlined by the white rectangle.

Figure 17. DEM dataset coverage around the study area. The CMS-Flow domain is outlined by the white rectangle. Note that DEM is finer in the nearshore region.

Figure 18. The bathymetric contours of ADCP and MBES survey data from June to November 2016.

Figure 19. Locations of Lake Michigan water level gauge 9087044 (Calumet Harbor, Illinois), NOAA buoy 45007 and the up-looking ADCP (BHSH001) site. The white rectangle designates the CMS domain. 
Figure 20. Water level data at Calumet Harbor gauge (9087044) for $7 / 20 / 2016$ to $8 / 31 / 2016$, and $10 / 10 / 2016$ to $11 / 20 / 2016$.

Figure 21. Wind roses for $7 / 20 / 2016$ to $8 / 31 / 2016$ and $10 / 10 / 2016$ to $11 / 20 / 2016$ at NDBC Buoy 45007.

Figure 22. Wind speeds and directions for $7 / 20 / 2016$ to $8 / 31 / 2016$, and $10 / 10 / 2016$ to $11 / 20 / 2016$, at NDBC Buoy 45007.

Figure 23. Wave roses for $7 / 20 / 2016$ to $8 / 31 / 2016$, and $10 / 10 / 2016$ to $11 / 20 / 2016$, at NDBC Buoy 45007.

Figure 24. Wave parameters for $7 / 20 / 2016$ to $8 / 31 / 2016$ and $10 / 10 / 2016$ to 11/20/2016 at NDBC Buoy 45007.

Figure 25. (a) Water surface elevation comparisons between the measurements and the CMS calculations and (b) pressure-derived water depth data at the ADCP Station, BHSHOO1 from 7/20/2016 to 8/30/2016.

Figure 26. Scatter plots of (a) the calculated and measured currents at the ADCP station, BHSH001, from $7 / 21 / 2016$ to $8 / 30 / 2016$, and (b) the calculated currents from 10/10/2016 to 11/20/2016. The blue line indicates the principal current axis, $\mathrm{U}$ is the east-west velocity component, and $\mathrm{V}$ is the north-south velocity component.

Figure 27. (a) Principal current comparisons between the measurements and the CMS calculations at the ADCP station BHSH001, from 7/20/2016 to $8 / 30 / 2016$, and (b) calculated principal currents from $10 / 10 / 2016$ to $11 / 20 / 2016$.

Figure 28. Calculated current field on 8/21/2016, at 04:00 GMT. The red rectangle indicates the nearshore ADCP bathymetry survey area, and the red dot is the location of the ADCP station, BHSHOO1.

Figure 29. Calculated current field on 11/11/2016, at 16:00 GMT. The red rectangle indicates the nearshore ADCP bathymetry survey area, and the red dot is the location of the ADCP station, BHSHOO1.

Figure 30. Wave parameter comparisons between the measurements and the CMS calculations at the ADCP Station, BHSHO01 from 7/20/2016 to 8/30/2016.

Figure 31. Calculated wave parameters at the ADCP location, BHSH001 from $10 / 10 / 2016$ to $11 / 20 / 2016$.

Figure 32. Calculated significant wave heights on 8/21/2016 at 04:00 GMT. The red rectangle indicates the nearshore ADCP bathymetry survey area.

Figure 33. Calculated significant wave heights on 11/11/2016, at 16:00 GMT.

The red rectangle indicates the nearshore ADCP bathymetry survey area.

Figure 34. Calculated mean current for the period of 10/10/2016 to

$11 / 15 / 2016$. The red rectangle indicates the nearshore ADCP bathymetry survey area, and the red dot is the location of the ADCP station, BHSHOO1.

Figure 35. Calculated mean sediment transport for the period of 10/10/2016 to $11 / 15 / 2016$. The red rectangle indicates the nearshore ADCP bathymetry survey area, and the red dot is the location of the ADCP station, BHSHOO1.

Figure 36. Nineteen transects perpendicular to the lake shoreline. The red rectangle indicates the nearshore ADCP bathymetry survey area, and the red dot is the location of the ADCP station, BHSHOO1. 
Figure 37. Measured and calculated profiles (transects 02-19) on 10/11/2016 and adjusted 11/15/2016 (red line - model; blue line - measured data).

Figure 38. Comparisons of morphology changes between the ADCP surveys and the CMS calculations from 10/11/2016 to $11 / 15 / 2016$. Warmer colors represent sediment accretion, and cooler colors sediment erosion. The ADCP survey difference measurements are (top panel) confined to the survey bounds (outlined region). The survey bounds are outlined in the CMS calculation differences (bottom panel), but the CMS calculations span the full model domain.

Figure 39. Areas that correspond to the three locations of calculated volume change in Table 6 from 10/11/2016 to 11/15/2016, for three nearshore areas. A1 is the entire survey area, A2 is the small erosional area, and A3 the large erosional area around dredge material placement sites.

Figure 40. Locations of the selected profile lines for the 06/02/2016, $10 / 11 / 2016$, and 11/15/2016 ADCP surveys plotted over the 10/11/2016 ADCP survey DEM.

Figure 41. DEM generated from the 06/02/2016 ADCP survey data.

Figure 42. DEM generated from the 10/11/2016 ADCP survey data merged with the 10/11/2016 RTK-dGPS beach survey data.

Figure 43. DEM generated from the 11/15/2016 ADCP survey data.

Figure 44. Rotation of the new alongshore/cross-shore coordinate system relative to the UTM $x, y$ coordinate system of the original data. The DEM is from the 10/11/2016 ADCP survey including beach topography.

Figure 45. Comparison of the 06/02/2016 (red), 10/11/2016 (blue), and 11/15/2016 (black) survey results for Profiles 1 (a), 2 (b), and 3 (c). Dashed black line indicates the line demarcating the placement region and the sandbar region. $\mathrm{X}_{\mathrm{cmin}}$ (black dotted line) is the minimum cross-shore position common to all three surveys.

Figure 46. Comparison of the 06/02/2016 (red), 10/11/2016 (blue), and 11/15/2016 (black) survey results for Profiles 4 (a), 5 (b), and 6 (c). Dashed black line indicates the line demarcating the placement region and the sandbar region. $x_{c m i n}$ (black dotted line) is the minimum cross-shore position common to all three surveys.

Figure 47. Comparison of the 06/02/2016 (red), 10/11/2016 (blue), and 11/15/2016 (black) survey results for Profiles 7 (a), 8 (b), and 9 (c). Dashed black line indicates the line demarcating the placement region and the sandbar region. $x_{c m i n}$ (black dotted line) is the minimum cross-shore position common to all three surveys.

Figure 48. Comparison of the 06/02/2016 (red), 10/11/2016 (blue), and 11/15/2016 (black) survey results for Profiles 10 (a), 11 (b), and 12 (c). Dashed black line indicates the line demarcating the placement region and the sandbar region. $x_{c m i n}$ (black dotted line) is the minimum cross-shore position common to all three surveys.

Figure 49. Comparison of the 06/02/2016 (red), 10/11/2016 (blue), and 11/15/2016 (black) survey results for Profiles 13 (a), 14 (b), and 15 (c). Dashed black line indicates the line demarcating the placement region and the sandbar region. $x_{\text {cmin }}$ (black dotted line) is the minimum cross-shore position common to all three surveys. 
Figure 50. Comparison of the 06/02/2016 (red), 10/11/2016 (blue), and 11/15/2016 (black) survey results for Profiles 16 (a), 17 (b), and 18 (c). Dashed black line indicates the line demarcating the placement region and the sandbar region. $x_{\text {cmin }}$ (black dotted line) is the minimum cross-shore position common to all three surveys.

Figure 51. Comparison of the 06/02/2016 (red), 10/11/2016 (blue), and 11/15/2016 (black) survey results for Profile 19 (a). Dashed black line indicates the line demarcating the placement region and the sandbar region. $x_{c m i n}$ (black dotted line) is the minimum cross-shore position common to all three surveys.

Figure 52. Elevation difference between the 10/11/2016 ADCP survey DEM and the 06/02/2016 ADCP survey DEM $(\Delta z=10 / 11 / 2016$ z - 06/02/2016 z).

Figure 53. Elevation difference between the 11/15/2016 ADCP survey DEM and the $10 / 11 / 2016$ ADCP survey DEM ( $\Delta z=11 / 15 / 2016$ z - 10/11/2016 z).

Figure 54. Elevation difference between the adjusted 11/15/2016 ADCP survey DEM and the 10/11/2016 ADCP survey DEM ( $\Delta \mathrm{z}=$ adjusted $11 / 15 / 2016 \mathrm{z}$ $10 / 11 / 2016 \mathrm{z})$

\section{Tables}

Table 1. List of historical dredging and placement locations near Ogden Dunes, Indiana

Table 2. Frequency of sediment mobilization and sediment migration direction under typical and storm wave conditions.

Table 3. Project timeline and data collection dates.

Table 4. CMS sediment transport model setup parameters.

Table 5. Sand bar locations in 19 measured transects on 10/11/2016 and 11/15/2016.

Table 6. Bed volume changes with the adjusted ADCP survey area from $10 / 11 / 2016$ to $11 / 15 / 2016$. Negative sign indicates bed erosion.

Table 7. Volume $(\mathrm{V})$ and the centroid location $\left(\mathrm{x}_{\mathrm{c}}, \mathrm{y}_{\mathrm{c}}\right)$ of each differenced surface (10/11/2016 - 06/02/2016 and unadjusted 11/15/2016 - 06/02/2016), as well as the change between the two post-placement surveys.

Table 8. Volume $(\mathrm{V})$ and the centroid location $\left(\mathrm{x}_{\mathrm{c}}, \mathrm{y}_{\mathrm{c}}\right)$ of each differenced surface (10/11/2016 - 06/02/2016 and adjusted 11/15/2016 - 06/02/2016), as well as the change between the two.

Table 9. Volume (V) of each differenced surface (10/11/2016 - 06/02/2016 and adjusted $11 / 15 / 2016-06 / 02 / 2016$ ) at $\mathrm{x}<180 \mathrm{~m}$ and $\mathrm{x}>180$, as well as the difference between the two.

Table 10. Volume per unit width $\left(\mathrm{V} / \mathrm{dy}-\mathrm{m}^{3} / \mathrm{m}\right)$ and the $\mathrm{x}$-centroid $\left(\mathrm{x}_{\mathrm{c}}\right)$ for each differenced profile $(10 / 11 / 2016$ - 06/02/2016 and adjusted 11/15/2016 06/02/2016) at all 19 profiles.

Table 11. Expected vs. observed volume change in the sandbar region $(x<180$ $\mathrm{m})$ and placement region $(x>180 \mathrm{~m}$ ) between the 10/11/2016 and $11 / 15 / 2016$. 


\section{Preface}

This study was conducted for the US Army Corps of Engineers (USACE), Regional Sediment Management (RSM) Program, and the USACE Chicago District, under Funding Account Code U4362913 and AMSCO Code 008303. The USACE National RSM program manager at the time of publication of this report was Dr. Katherine Brutsché.

The work was performed by the Coastal Engineering and Coastal Observation Analysis Branches of the Navigation and Flood and Coastal Divisions, US Army Engineer Research and Development Center, Coastal and Hydraulics Laboratory (ERDC-CHL). At the time of publication of this report, Ms. Lauren Dunkin was Chief, Coastal Engineering Branch, and Dr. Jeffrey Waters was Chief, Coastal Observation Analysis Branch; Dr. Jacqueline S. Pettway was Chief, Navigation Division, and Dr. Cary Talbot was Chief, Flood and Coastal Division; and Mr. Charles E. Wiggins (CHL) was the ERDC Technical Director for Navigation. The Deputy Director of ERDC-CHL was Mr. Jeffrey R. Eckstein, and the Director was Dr. Ty V. Wamsley.

COL Teresa A. Schlosser was the Commander of ERDC, and the Director was Dr. David W. Pittman. 


\section{Introduction}

\subsection{Background}

The study area is located approximately 45 kilometers $(\mathrm{km})$ southeast of Chicago, Illinois, in the Town of Ogden Dunes, Indiana, and the adjacent Indiana Dunes National Lakeshore in Portage, Indiana. The beach of the Indiana Dunes National Lakeshore is one of the few remaining undeveloped areas along the southern shoreline of Lake Michigan. This National Park Service (NPS) area contains critical natural resources (e.g., 1,100 species of flowering plants and ferns, 350 species of birdsparticularly migrating land and water birds, beaches for recreation [NPS 2015]) and coastal habitat, as well as providing public access to Lake Michigan (Arnold et al. 2018). The development along the beach of Ogden Dunes is residential. The shoreline of Ogden Dunes and the Indiana Dunes National Lakeshore is located approximately $2 \mathrm{~km}$ west of a highly developed portion of the southern shoreline of Lake Michigan, including the Port of Indiana and Burns Harbor (Figure 1).

Figure 1. Location of the study area and nearby locations of interest.

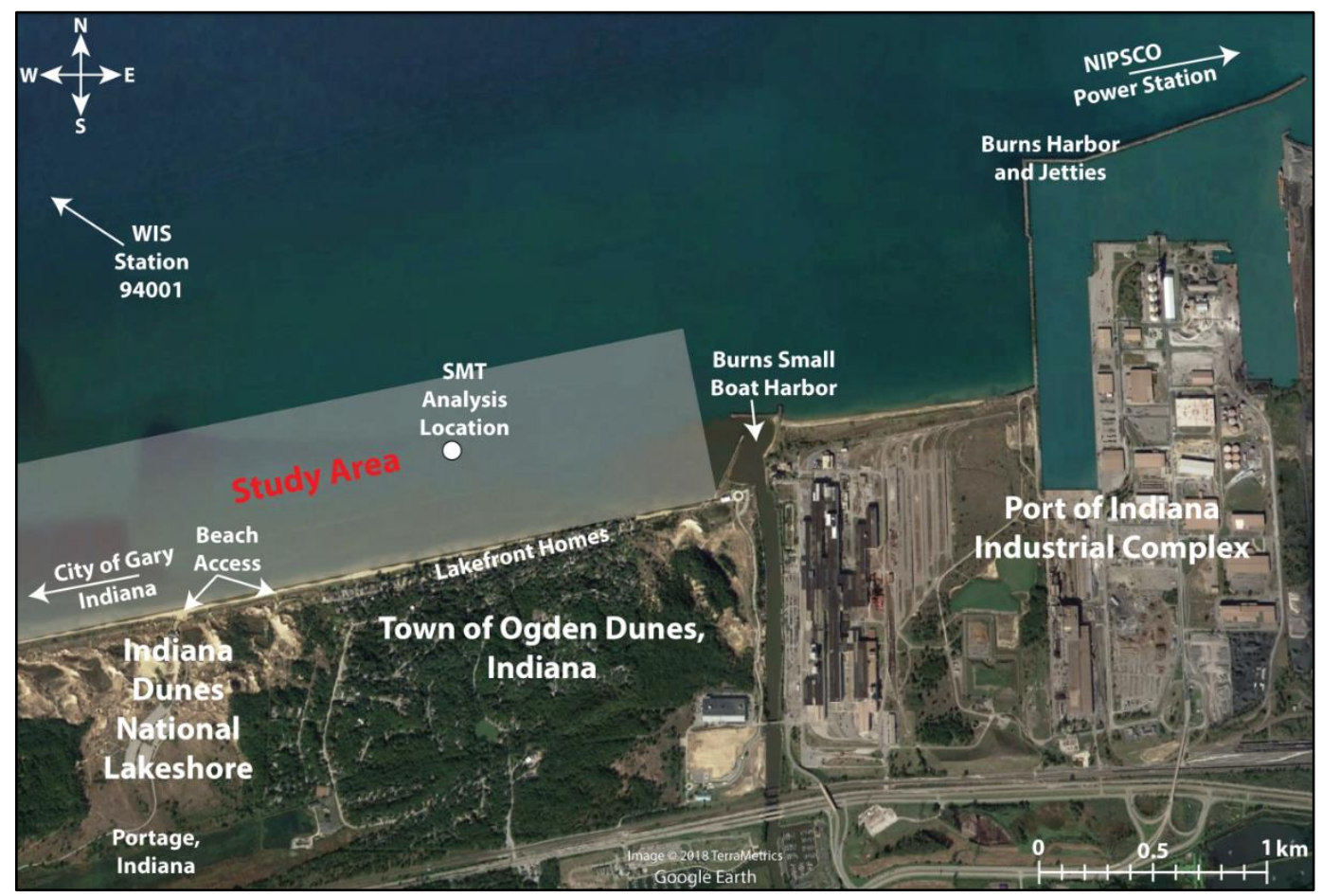


Burns Harbor was constructed in 1968 and consists of a north/northeastfacing rubble mound breakwater, as well as a west-facing rubble mound and armor stone bulkhead/jetty (Tyler et al. 2018). The Burns Small Boat Harbor, located approximately 800 meters (m) west of the Burns Waterway Harbor, includes an east/west facing rubble mound jetty, a north-facing rubble mound breakwater, and a northwest-facing jetty (Tyler et al. 2018). The predominant direction of littoral transport in this region is east-to-west (Arnold et al. 2018), and the natural transport has been interrupted by these structures. As a consequence, several coastal sediment management issues have developed in the vicinity of Burns Waterway Harbor, such as (1) a substantial volume of sediment is accumulating along the rubble mound containment jetty to the east of Burns Harbor Waterway, (2) maintenance dredging of the ship channel has been required more frequently than historically typical due to infilling of the ship channel, and (3) the shoreline west of Burns Waterway Harbor (such as the Indiana Dunes National Lakeshore and the Town of Ogden Dunes, Indiana) has substantially eroded (Tyler et al. 2018; Arnold et al. 2018).

In addition to those structures in the vicinity that impact the volume of beach sand observed in the Town of Ogden Dunes, Indiana, and adjacent Indiana Dunes National Lakeshore, natural controls on sediment transport also exist. Lake Michigan water levels fluctuate cyclically and are influenced by factors such as precipitation, evaporation, and ice cover (Figure 2; USACE LRC 1995). Sustained high winds from the north also can increase water levels at the southern end of the lake during a storm, a phenomenon known as seiching. The erosion issues in the area to the west of the industrial complex become particularly acute during periods of high lake levels and storm events when the high water level pushes the large waves farther inland and higher onto the beach and limits wave breaking over sandbar features. Furthermore, the substantial water level increase in Lake Michigan since 2013 may partially account for the apparent beach erosion as empirically based models indicate accretionary typical wave conditions (Arnold et al. 2018). 
Figure 2. Lake Michigan lake levels, including seasonal averages (1960-2018).

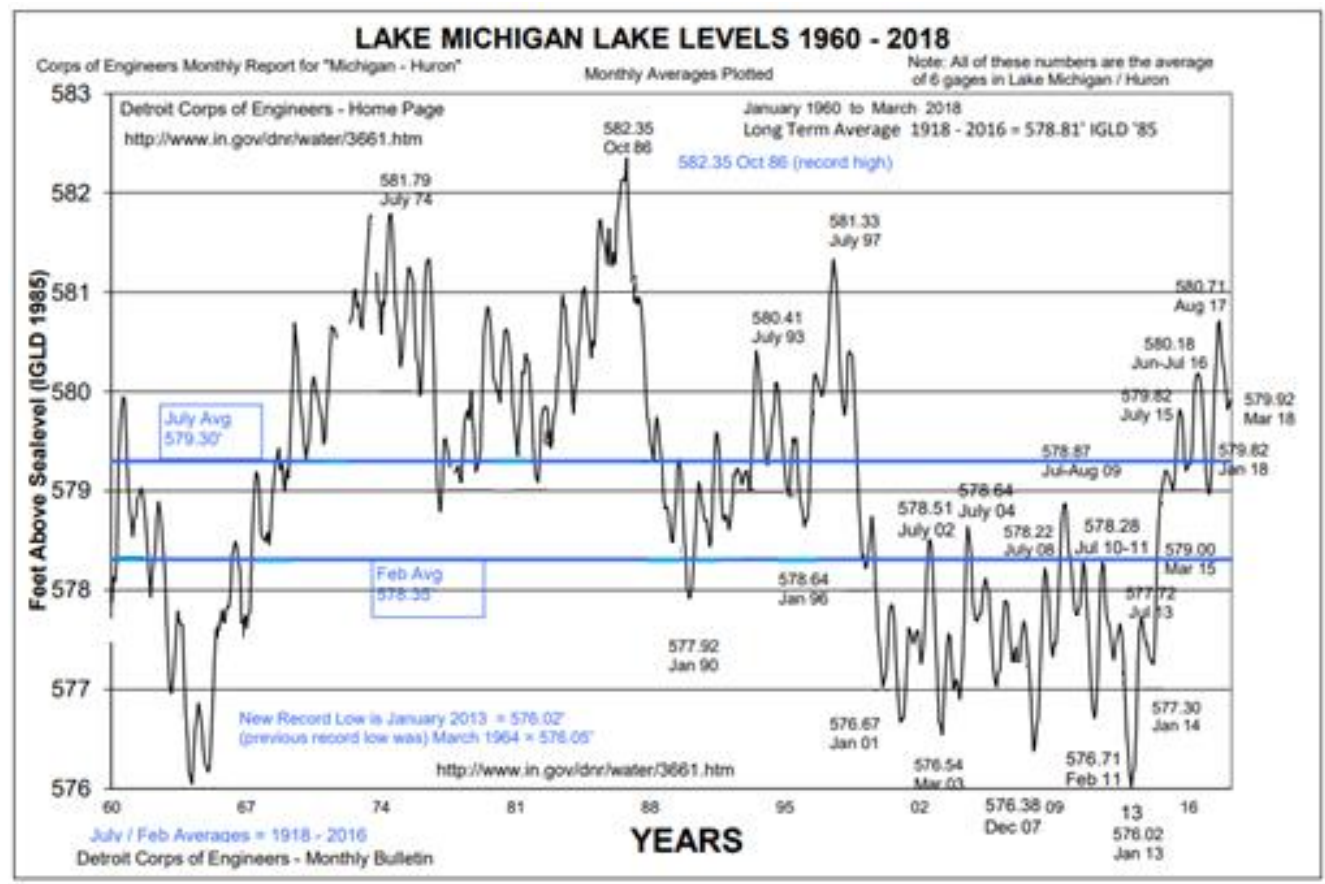

Sediment from dredging activities in the surrounding area is primarily fine sediment suitable for beach nourishment. The US Army Corps of Engineers (USACE) has placed over 450,000 cubic meters (m3) of dredged material since 2006 in the nearshore area of this reach as part of an effort to protect the rare and significant natural habitat at the National Lakeshore, along with shoreline residences within Ogden Dunes. The nearshore placement of dredged material offers reduced cost relative to placement directly on the beach, but the shoreline response to the nearshore placements compared to direct beach placement has not been quantified.

The USACE efforts to better understand and respond to the continual shoreline erosion have been spearheaded by the Regional Sediment Management (RSM) Program with cooperation from the USACE districts (e.g., USACE Chicago District). The RSM program is a high-level, systemsbased approach to sediment management at regional scales across multiple projects (Lillycrop et al. 2011; Morang et al. 2012; Schrader et al. 2016; Arnold et al. 2018). The program was implemented in 1999 to improve upon the historical sediment management practices of the USACE (i.e., management at a local scale within individual projects). The narrow focus of the older, local scale approach does not best consider the impacts on adjacent projects or the regional scale sediment transport 
processes that may be affected. The holistic, regional-scale approach of the RSM program allows the USACE and stakeholders to better consider the net effects of multiple adjacent projects. Substantial cost savings may be realized due to efficient cost sharing across projects, such as combined permit actions, reduced dredge mobilization/demobilization costs, and reduced project timelines. The adaptive management aspect of RSM involves implementation of pilot projects in combination with USACE districts and stakeholders. Each sediment management practice within pilot projects is evaluated to determine successful strategies and areas of improvement in subsequent pilot projects. When used in conjunction with the collaboration fostered by the regional cross-project approach of RSM, the adaptive management also allows for more efficient dissemination of knowledge and transfer of best practices (Lillycrop et al. 2011). The net effect of the new sediment management style of the RSM program is marked improvement in the USACE ability to reduce project life-cycle costs and better support sustainable navigation, dredging, and storm and flood damage risk reduction while retaining best environmental practices that value sediment as a natural resource and considers the ecosystem/environmental benefits (Rosati et al. 2001).

\subsection{Objectives}

Through the RSM program and the USACE Chicago District, the USACE evaluated and monitored the artificial placement and natural transport of material into the nearshore region of the beach at Ogden Dunes. The objective of this monitoring is to improve the effectiveness of nearshore placement at Ogden Dunes and to ensure that it fulfills its primary design purpose - erosion mitigation. Specifically, this report seeks to observe and quantify (1) the migration of the nearshore placement material, (2) changes in the adjacent Ogden Dunes beach, and (3) reductions in wave energy on the beach as a result of increased wave breaking and dissipation over the nearshore placement site.

\subsection{Approach}

The monitoring plan for this nearshore placement involved data collection to measure the nearshore bathymetry and beach topography as well as the hydrodynamic forcing conditions. Two bottom-mounted, upward-facing acoustic Doppler current profilers (ADCPs) were deployed to quantify the currents and wave conditions prior to, during, and post nearshore placement, one offshore of the placement site and one onshore. Seven 
bathymetric surveys were conducted, one prior to the nearshore placement and six over the 5 months post-placement. Two beach topography and shallow-water $(<1 \mathrm{~m})$ bathymetry surveys were conducted, the first 1 month post-placement and the second 4 months post-placement. Note that only two of the six post-placement bathymetry surveys were used in the subsequent analysis due to the presence of an unexpected dredge operating in the study area during a portion of the nearshore placement monitoring. The placement by the unexpected dredge was not coordinated with the study authors, and the location and volume of sediment placed in the study area could not be determined. Additionally, one of the wavemonitoring ADCPs was buried and could not be recovered.

These data are analyzed and combined with modeling efforts performed in the Coastal Modeling System (CMS) suite of nearshore hydrodynamic and sediment transport models to accomplish the objectives of this study. The goals of this study and the RSM program are to support more sustainable shoreline management practices, protect valuable natural resources, and improve the efficiency of federal and stakeholder investments.

\subsection{Report layout}

This report details the following information: (1) a brief overview of the issues facing the Town of Ogden Dunes and the undeveloped shoreline in Indiana Dunes National Lakeshore, (2) a description of the Town of Ogden Dunes, Indiana, and the study area of the nearshore placement monitoring, (3) the results of the Sediment Mobility Tool (SMT) analysis of the conditions near Ogden Dunes, Indiana, to determine the optimal sediment placement depth and the predicted migration of sediment placed in the nearshore, (4) a description of the historical dredging and sediment placement at Ogden Dunes as well as the 2016 nearshore placement monitored in the course of this study, (5) a thorough review of the field data collection methods and procedures for obtaining the hydrodynamic, bathymetric, and topographic data analyzed in this report, (6) the results of the CMS modeling efforts, (7) a discussion of the morphology change detected in the field data, and (8) concluding remarks. 


\section{Study Area}

The study area is located within the Town of Ogden Dunes, Indiana, and the Indiana Dunes National Lakeshore (Figure 1), located in the town of Portage, Indiana. The land adjacent to the lake within the National Lakeshore is managed by the NPS for conservation and public access. The land use adjacent to the lake in Ogden Dunes is residential. The land directly west of the study area is located within the City of Gary. This land use also is residential, but there is a greater setback between homes and the shore zone than in Ogden Dunes (Town of Ogden Dunes 2013; City of Gary 2019). The large Port of Indiana industrial complex is located directly east of the study area.

The southern shoreline of Lake Michigan is highly developed, and the presence of harbor structures and shoreline armoring interrupts the natural littoral movement of sand. Net littoral transport in this area is from east to west, so sediment accretes at the east side of the Port of Indiana industrial complex and Northern Indiana Public Service Company (NIPSCO) power generation facility, leaving the downdrift study area sand starved. Erosion is a concern to both the residents of Ogden Dunes and NPS, as natural buffering systems and public access are reduced during periods of high lake levels. Lakeshore properties have been left exposed as a result of erosion and lack of sand replenishment, leaving them at greater risk to coastal hazards. Public access to the beach at the NPS Portage Lakefront and Riverwalk has become limited due to unsafe conditions caused by erosion (Figure 3).

Figure 3. Erosion impacts on private residences and public access within the study area.

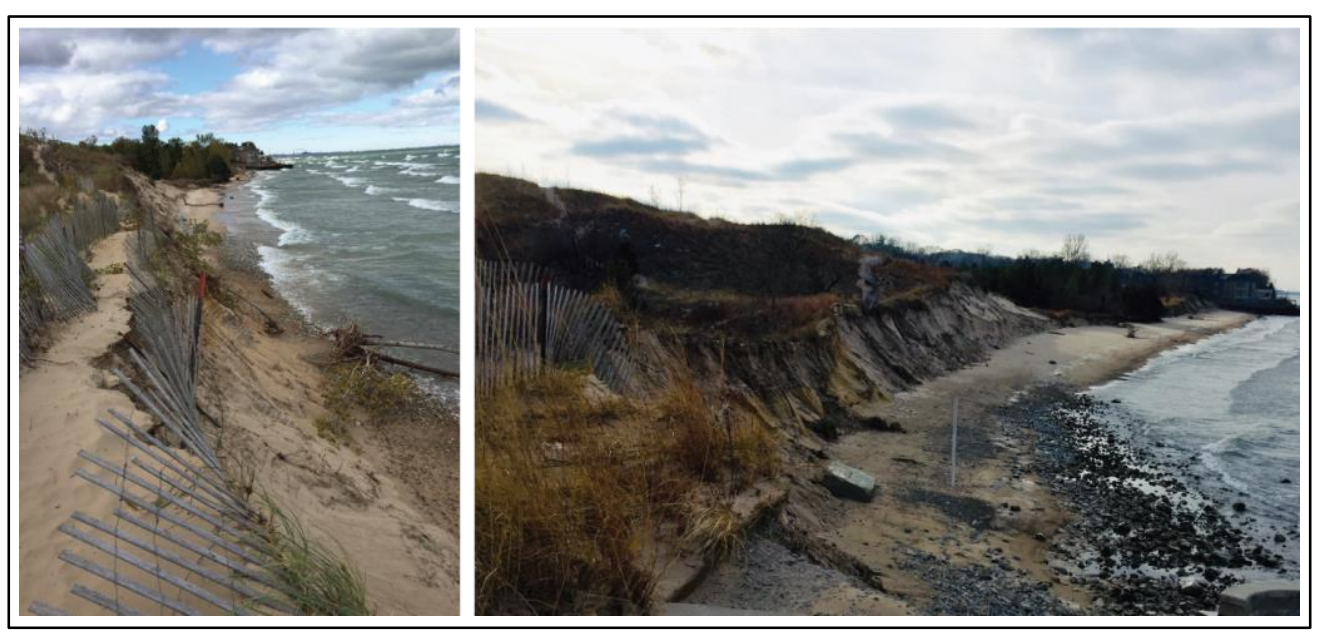




\section{Dredging and Nearshore Placement at Ogden Dunes}

\subsection{Historical}

Dredging records spanning the years 1980 to 2016 for the Port of Indiana Harbor, Burns Small Boat Harbor, and the nearby NIPSCO water intake area (Arnold et al. 2018) were used to develop the historical dredging record in the vicinity of the Town of Ogden Dunes, Indiana. These areas were dredged by both NIPSCO and the USACE; the total volumes dredged and the placement locations for the dredged material are listed in Table 1. Figure 4 shows the placement locations on a regional map for reference.

Table 1. List of historical dredging and placement locations near Ogden Dunes, Indiana.

\begin{tabular}{|c|c|c|c|c|}
\hline Project & Year & $\begin{array}{l}\text { Quantity } \\
\text { (cubic } \\
\text { meters) }\end{array}$ & $\begin{array}{c}\text { Quantity } \\
\text { (cubic } \\
\text { yards) }\end{array}$ & Placement Location \\
\hline \multirow{8}{*}{$\begin{array}{l}\text { Port of } \\
\text { Indiana } \\
\text { Harbor }\end{array}$} & 1996 & 203,000 & 266,000 & Open lake placement - Area A \\
\hline & 2007 & 174,000 & 228,000 & Open lake placement - Area A \\
\hline & 2008 & 42,000 & 55,000 & Open lake placement - Area A \\
\hline & 2013 & 54,000 & 70,000 & Nearshore placement - Area D \\
\hline & 2014 & 50,000 & 65,000 & Nearshore placement - Area B \\
\hline & 2014 & 54,000 & 70,000 & Nearshore placement - Area B \\
\hline & 2015 & 42,000 & 55,000 & Nearshore placement - Area B \\
\hline & 2016 & 57,000 & 75,000 & Nearshore placement - Area B \\
\hline \multirow{4}{*}{$\begin{array}{c}\text { Burns } \\
\text { Small Boat } \\
\text { Harbor }\end{array}$} & 1985 & 46,000 & 59,000 & Beach placement - Area C \\
\hline & 1986 & 51,000 & 67,000 & Beach placement - Area C \\
\hline & 2000 & 109,000 & 143,000 & Beach placement - Area C \\
\hline & 2009 & 61,000 & 80,000 & Nearshore placement - Area B \\
\hline \multirow{5}{*}{$\begin{array}{l}\text { NIPSCO } \\
\text { Intake } \\
\text { (NIPSCO } \\
\text { Dredged) }\end{array}$} & 1980 & 210,000 & 275,000 & $\begin{array}{l}\text { Unspecified open lake } \\
\text { placement }\end{array}$ \\
\hline & 1982 & 167,000 & 218,000 & Shoreline at BGS \\
\hline & 1986 & 245,000 & 320,000 & Nearshore placement - Area B * \\
\hline & 1989 & 220,000 & 288,000 & Nearshore placement - Area B * \\
\hline & 1992 & 160,000 & 209,000 & Nearshore placement - Area B * \\
\hline
\end{tabular}




\begin{tabular}{|c|c|c|c|c|}
\hline Project & Year & $\begin{array}{l}\text { Quantity } \\
\text { (cubic } \\
\text { meters) }\end{array}$ & $\begin{array}{l}\text { Quantity } \\
\text { (cubic } \\
\text { yards) }\end{array}$ & Placement Location \\
\hline & 1995 & 90,000 & 118,000 & Nearshore placement - Area B * \\
\hline & 1997 & 112,000 & 146,000 & Nearshore placement - Area B * \\
\hline & 1999 & 126,000 & 165,000 & Nearshore placement - Area B * \\
\hline & 2016 & 50,000 & 65,000 & Nearshore placement - Area B \\
\hline \multirow{4}{*}{$\begin{array}{l}\text { NIPSCO } \\
\text { Intake } \\
\text { (USACE } \\
\text { Dredged) }\end{array}$} & 2006 & 23,000 & 30,000 & Nearshore placement - Area B \\
\hline & 2007 & 174,000 & 228,000 & Nearshore placement - Area B \\
\hline & 2008 & 80,000 & 105,000 & Nearshore placement - Area B \\
\hline & 2009 & 84,000 & 110,000 & Nearshore placement - Area B \\
\hline
\end{tabular}

* NIPSCO 1986 to 1999 dredges placed 75\% of the material nearshore at Ogden Dunes and 25\% nearshore at Beverly Shores, Indiana (not shown).

Figure 4. Nearshore placement locations near the Town of Ogden Dunes, Indiana. Adapted from Arnold et al. (2018), with permission.

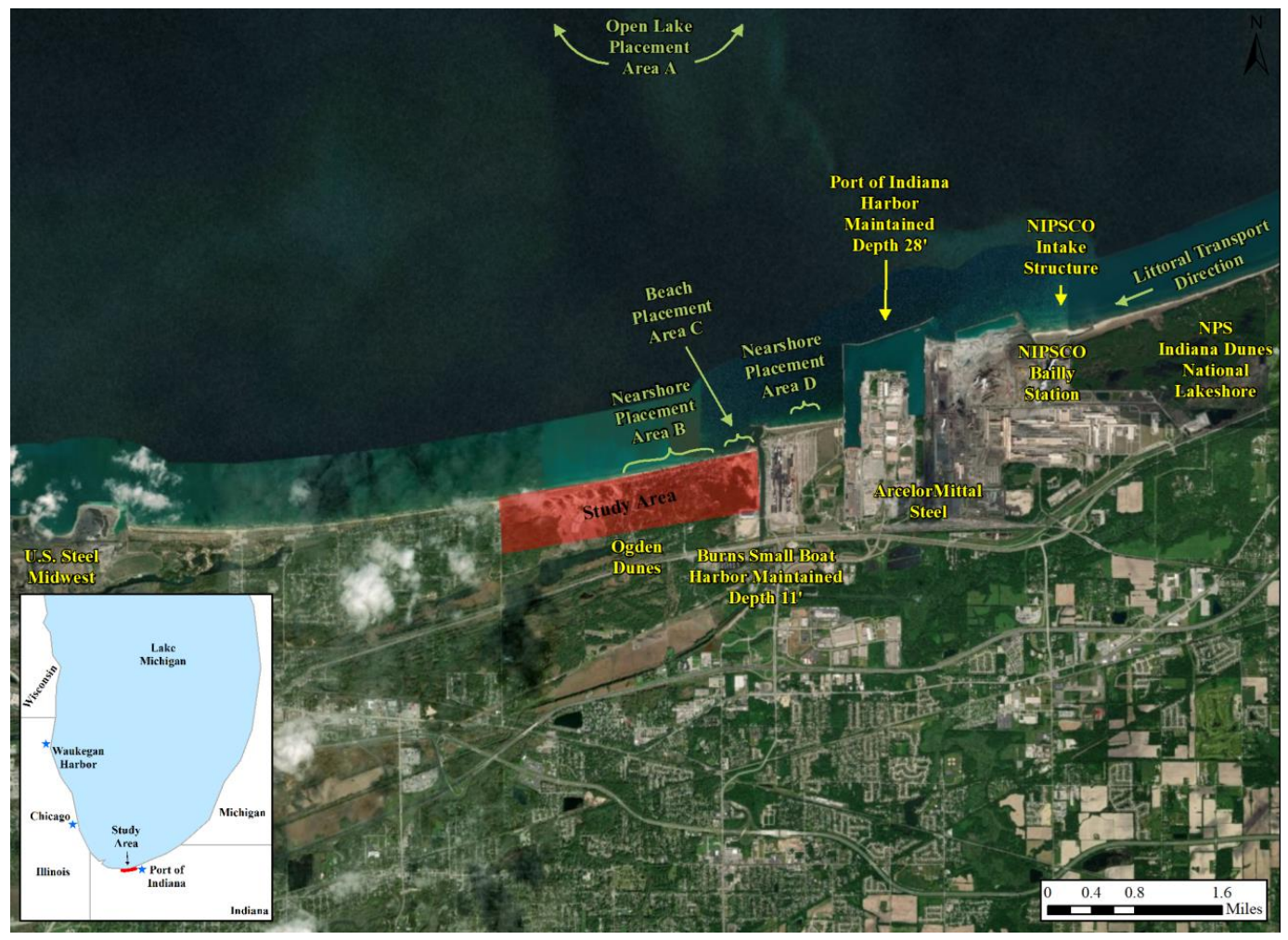

Table 2 indicates that dredging projects in the years 1996 and 2007 at the Port of Indiana were larger ( $\left.>174,000 \mathrm{~m}^{3}\right)$ but less frequent than in 20082016 ( $<61,000 \mathrm{~m}^{3}$ ). The dredged material was placed offshore (Area A) prior to 2009. Beginning in 2013, all dredged material was placed in the 
nearshore region (Area D in 2013; Area B from 2014 on). The Burns Small Boat Harbor dredging projects generally were smaller $\left(<61,000 \mathrm{~m}^{3}\right)$ than at the Port of Indiana, with the exception of a larger undertaking in 2000 $(109,000 \mathrm{~m} 3)$. All the dredged material was placed on the beach (Area C) or in the nearshore near Ogden Dunes, Indiana (Area B). The NIPSCO intake dredging projects generally were larger in scope than the Port of Indiana or Burns Small Boat Harbor projects, with all NIPSCO-dredged projects between 1980 and 1992, as well as the 2007 USACE dredging, equaling or exceeding $160,000 \mathrm{~m}^{3}$. Most of the dredged material from this site was placed in the nearshore at Ogden Dunes, Indiana. Many of the NIPSCO-dredged material placements, however, were split between the nearshore at Ogden Dunes (75\%) and at Beverly Shores, Indiana (25\%). As per these historical records, the primary source of the nearshore placement material in the nearshore at Ogden Dunes, Indiana, was dredged from the NIPSCO intake.

\subsection{6 dredging and placement}

The nearshore placement that is the focus of this study took place in June and July of 2016. A total of 107,000 $\mathrm{m}^{3}$ of dredged material from the Port of Indiana and NIPSCO intake was placed in the nearshore region of the Town of Ogden Dunes, Indiana, at a depth of approximately $5.5 \mathrm{~m}$. Note that this placement does not appear in the records of historical placements shown in Table 1. The elevation difference between the pre-placement and first post-placement survey in Figure 5 show that the shape of the offshore placement resembles an offshore mound with a series of discrete identifiable peaks, centered roughly at Universal Transverse Mercator (UTM) $x=484,400 \mathrm{~m}$; UTM $y=4,609,125 \mathrm{~m}$. 
Figure 5. Elevation difference between the 10/11/2016 ADCP survey digital elevation model (DEM) and the 6/2/2016, ADCP survey DEM showing the offshore mound and identifiable peaks.

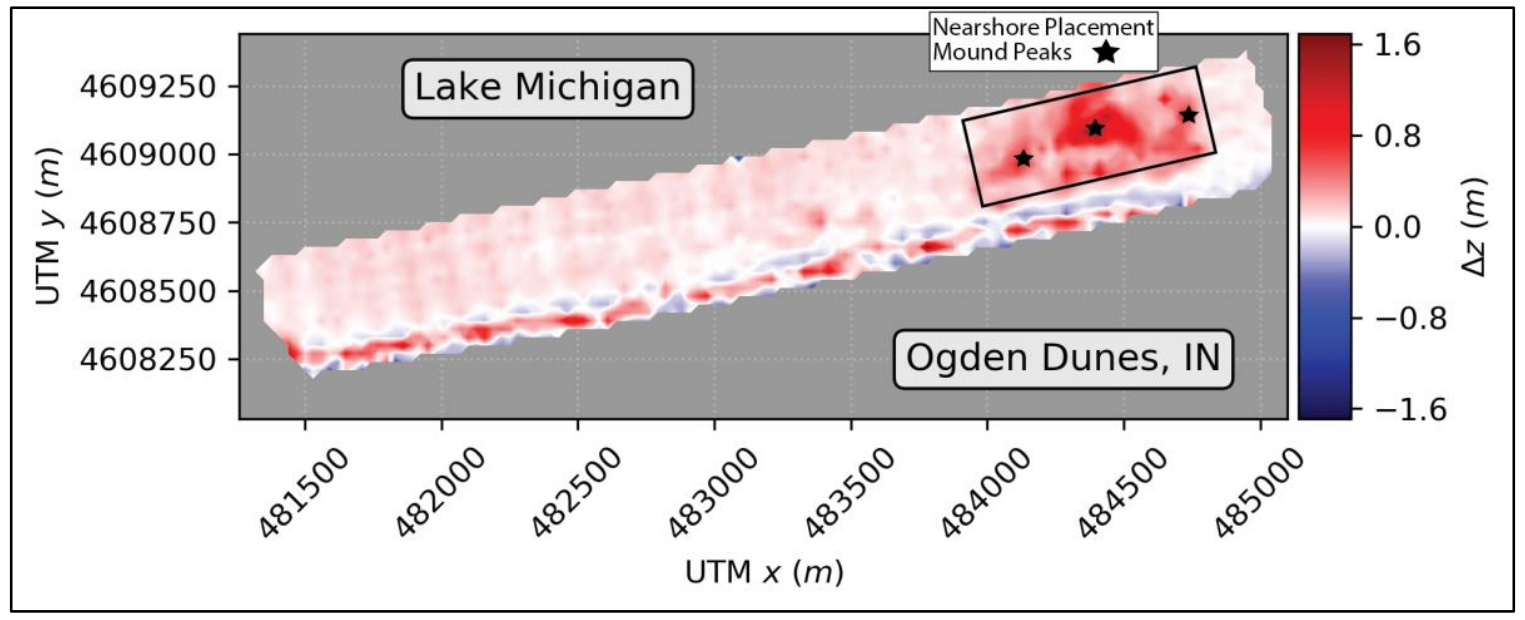

The volume of the placed material was comparable to those made by the NIPSCO and USACE dredges at the same site. Note that an independent dredging barge was observed working in the study area for NIPSCO on 9/8/2016, unrelated to the planned June and July 2016 nearshore placement. It is therefore likely that the total volume of sediment placed in the study site between the pre-placement and post-placement surveys exceeded 107,000 m3. 


\section{Sediment Mobility Tool (SMT)}

The SMT (http://cirp.usace.army.mil/products/sedmobility.php) is a scoping level tool used to assist engineers and planners in siting nearshore placement of dredged material. The tool calculates the frequency of sediment mobility using linear and non-linear wave theories, onshore or offshore sediment transport based on Larson and Kraus (1992), and the direction of alongshore sediment migration based on the axis of wave-dominated sediment transport in the study area. To calculate these parameters, waves from a nearby USACE Wave Information Study (WIS) hindcast station were propagated into the nearshore site using Snell's Law. (More details regarding equations used in each calculation can be found in McFall et al. [2016]).

At Ogden Dunes, the SMT was applied to determine best practices (i.e., optimal placement depth) of placing sediment in the nearshore. The tool was run (see Figure 1 for location) using the maximum depth allowed in the nearshore placement permit, $5.5 \mathrm{~m}$, to determine whether sediment would move once placed. The tool was run under both typical and storm wave conditions to determine any differences in mobility and transport direction. Wave hindcasts from WIS Station 94001 (Figure 1), approximately $6.4 \mathrm{~km}$ offshore, were used, and the mean background current $1 \mathrm{~m}$ above the bed was assumed to be 0.05 meters per second $(0.05 \mathrm{~m} / \mathrm{s})$ alongshore to the west as in Arnold et al. (2018). A median grain size, $\mathrm{d}_{50}$, of 0.15 millimeter $(\mathrm{mm})$ was used (Appendix A).

Figure 6 and Figure 7 show results of the SMT under typical and storm waves for the study area. In the histograms, the vertical dashed lines denote the bed stress or near-bed velocity required to mobilize a certain grain size (indicated in the legend). All values of bed stress and velocity to the right of the vertical dashed lines would be capable of transporting sediment, and the frequency is calculated based on the number of waves at the given bed stress or near-bed velocity. According to the histograms, the sediment in the study area with grain size of $0.15 \mathrm{~mm}$ was predicted to be mobilized under $37 \%-48 \%$ of the waves during typical wave conditions. Table 2 summarizes the frequency of mobility as well as the onshore/offshore migration during typical and storm wave conditions. The frequency of mobilization under storm conditions increases to $76 \%-84 \%$. Sediment migration was predominantly directed onshore during both 
typical and storm wave conditions; however, typical wave conditions were predicted to create more onshore migration than storm conditions ( $91 \%$ compared to $72 \%$, respectively). Dominant wave direction was out of the north-northwest during both typical and storm conditions (Figure 8 and Figure 9).

Figure 6. Histogram showing frequency of sediment mobility using linear wave theory under typical wave conditions. Reprinted from Arnold et al. (2018), with permission.

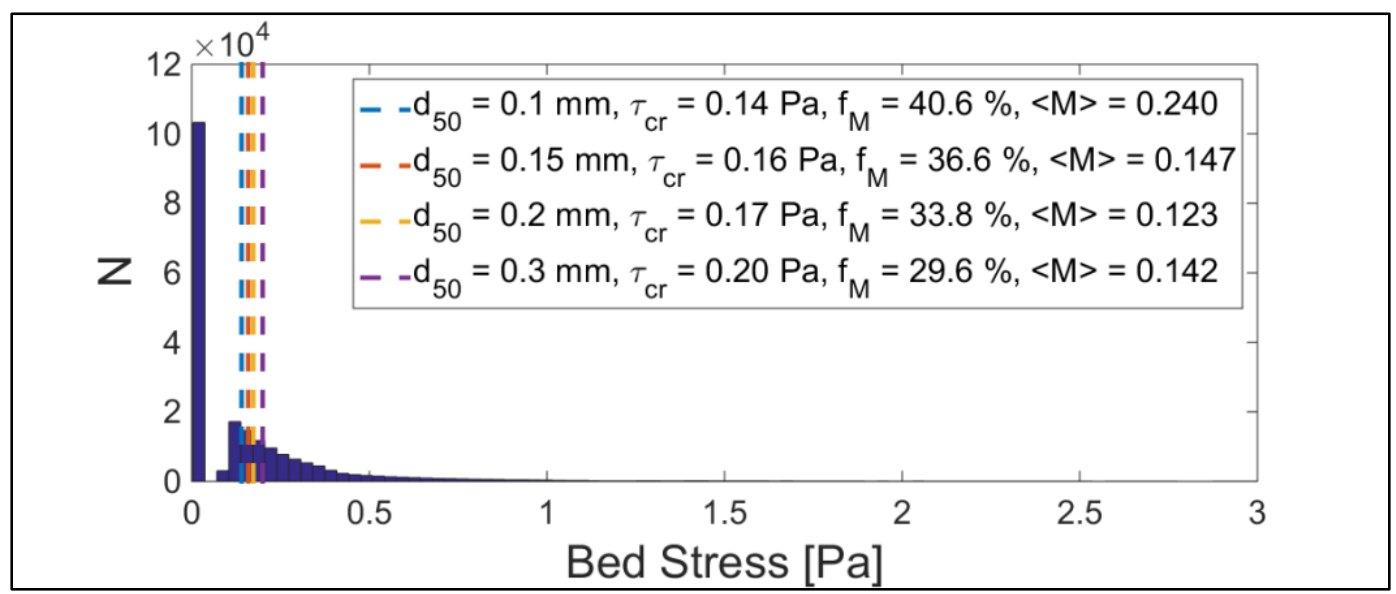

Figure 7. Histogram showing frequency of sediment mobility using non-linear wave theory under storm wave conditions. Reprinted from Arnold et al. (2018), with permission.

\begin{tabular}{|c|c|c|}
\hline \\
$Z$ \\
\hline
\end{tabular}


Table 2. Frequency of sediment mobilization and sediment migration direction under typical and storm wave conditions.

\begin{tabular}{|c|c|c|c|c|}
\hline \multirow{2}{*}{$\mathbf{d}_{50}(\mathrm{~mm})$} & \multicolumn{2}{|c|}{ Typical Waves } & \multicolumn{2}{c|}{ Storm Events } \\
\cline { 2 - 5 } & $\begin{array}{c}\text { Frequency of } \\
\text { Mobilization }\end{array}$ & $\begin{array}{c}\text { Sediment } \\
\text { Migration }\end{array}$ & $\begin{array}{c}\text { Frequency of } \\
\text { Mobilization }\end{array}$ & Sediment Migration \\
\hline 0.1 & $41 \%-54 \%$ & $68 \%$ Onshore & $79 \%-87 \%$ & $51 \%$ Offshore \\
\hline 0.15 & $37 \%-48 \%$ & $91 \%$ Onshore & $76 \%-84 \%$ & $72 \%$ Offshore \\
\hline 0.2 & $34 \%-44 \%$ & $97 \%$ Onshore & $73 \%-81 \%$ & $85 \%$ Onshore \\
\hline 0.3 & $30 \%-38 \%$ & $99 \%$ Onshore & $68 \%-76 \%$ & $96 \%$ Onshore \\
\hline
\end{tabular}

Figure 8. Dominant wave direction during typical wave conditions. $\mathrm{H}_{\mathrm{mo}}$ is equal to four times the standard deviation of the sea surface elevations.

Reprinted from Arnold et al. (2018), with permission.

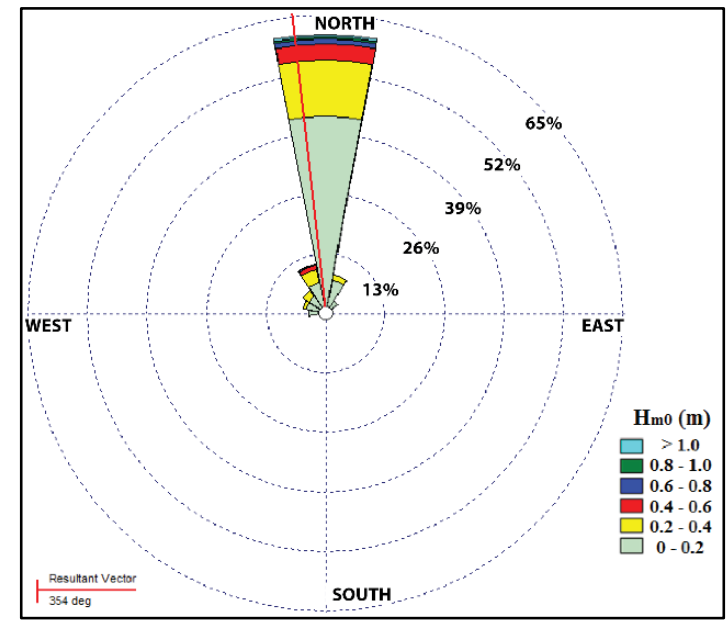

Figure 9. Dominant wave direction during storm wave conditions. Reprinted from Arnold et al. (2018), with permission.

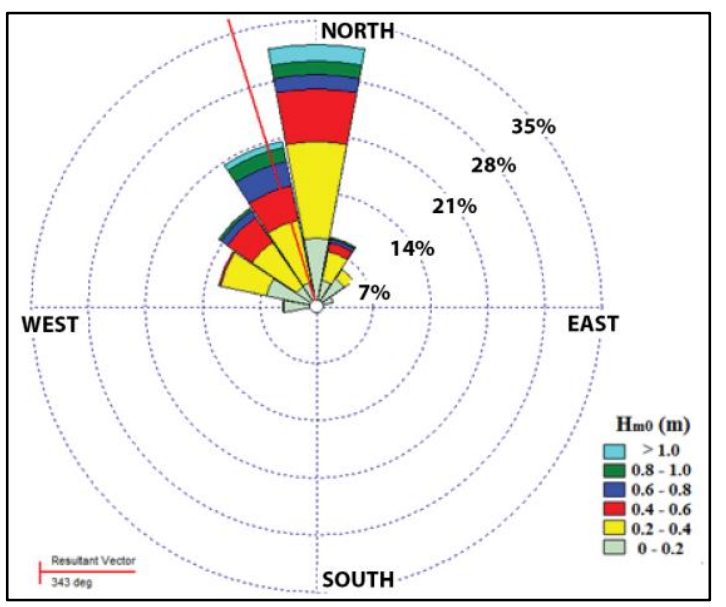




\section{Field Data Collection Methods}

Nearshore hydrodynamic and bathymetric data were collected at the Burns Harbor/Ogden Dunes study site from June 2016 through November 2016 (Duncker et al. 2017). The study site consisted of a rectangular area approximately $4 \mathrm{~km}$ (shore-parallel) by $0.72 \mathrm{~km}$ (cross-shore), and included subaerial areas on the beach as well as offshore areas out to depths of approximately 7.5 to $9.1 \mathrm{~m}$ depending on position (Figure 10). Timelines were established for the data collection to ensure that hydrodynamic data and bathymetric surveys were collected both before and after placement of dredged material (Table 3). Hydrodynamic data were collected using two stationary upward-profiling ADCPs (Figure 11). Boat-mounted, downwardprofiling ADCPs were used for five bathymetric surveys, and two highresolution bathymetric surveys were acquired using a multibeam echosounder (MBES). The bathymetric surveys were supplemented with two Real Time Kinematic differential Global Positioning System (RTKdGPS) topographic surveys of the subaerial and shallow portions of the beach (Figure 12). In addition to the planned placement of dredged material, which occurred between June 15, 2016, and July 15, 2016, an independent dredging barge was observed working in the study area for NIPSCO on 9/8/2016 (Figure 13). The results from the data collections are presented in Sections 6 and 7 of this report.

Table 3. Project timeline and data collection dates.

\begin{tabular}{|l|l|}
\hline Date & Activity \\
\hline $5 / 31 / 2016$ & $\begin{array}{l}\text { Deployment of two stationary upward-profiling ADCPs, programmed to begin } \\
\text { data collection on June 2, 2016 }\end{array}$ \\
\hline $6 / 2 / 2016$ & First ADCP bathymetric survey \\
\hline $6 / 10 / 2016$ & Email notice that dredging starts on June 15 \\
\hline $6 / 15 / 2016$ & Dredging to start \\
\hline $7 / 15 / 2016$ & End dredge placement \\
\hline $7 / 20 / 2016$ & Second ADCP bathymetric survey \\
\hline $7 / 25 / 2016$ & $\begin{array}{l}\text { First MBES bathymetric survey, conducted by US Geological Survey, Indiana- } \\
\text { Kentucky Water Science Center (USGS-INKY) }\end{array}$ \\
\hline $8 / 9 / 2016$ & RTK-dGPS beach survey \\
\hline $9 / 8 / 2016$ & $\begin{array}{l}\text { Third ADCP bathymetric survey; second MBES bathymetric survey conducted } \\
\text { by USGS-INKY; photo of NIPSCO barge placing dredge material (Figure 13) }\end{array}$ \\
\hline $10 / 11-12 / 2016$ & Fourth ADCP bathymetric survey; RTK-dGPS beach survey \\
\hline $10 / 28 / 2016$ & $\begin{array}{l}\text { Attempted recovery of the two stationary upward-profiling ADCPs, only one } \\
\text { was recovered }\end{array}$ \\
\hline $11 / 15 / 2016$ & Fifth ADCP bathymetric survey \\
\hline
\end{tabular}


Figure 10. Google Earth image of Lake Michigan near Ogden Dunes, Indiana. The dredge placement area is outlined by the yellow rectangle. Bathymetric survey lines are shown in black, and two upward-looking ADCPs are shown as red stars.

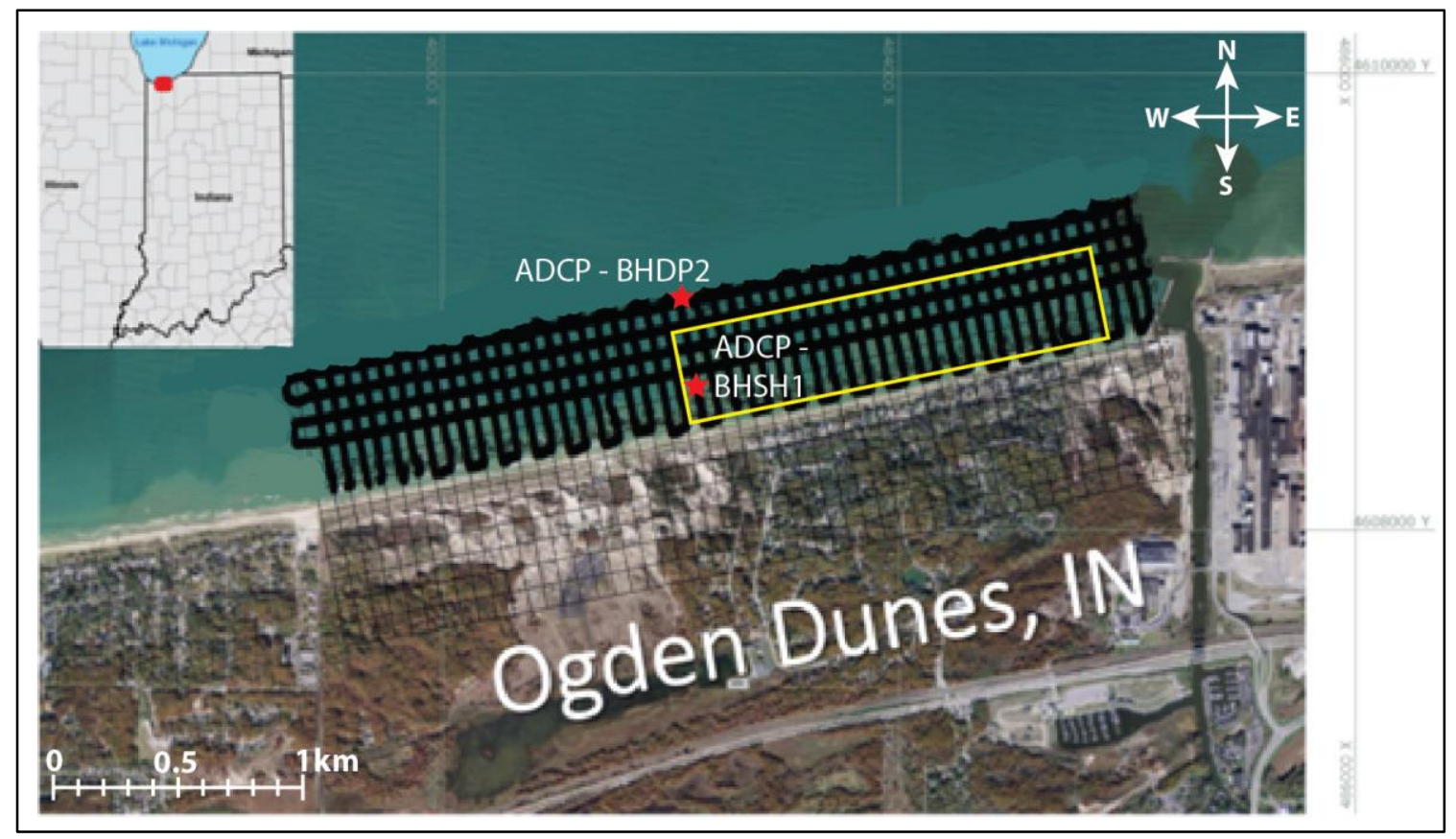

\subsection{Wave and current data}

Two Teledyne-RD Instrument (TRDI) 1200 kilohertz (kHz) Workhorse Sentinel ADCPs were deployed along a nearshore-to-offshore transect approximately perpendicular to the shoreline (Figure 10). Both ADCPs were deployed to their position on the lake bottom on $5 / 31 / 2016$, and programmed to begin data collection on 6/2/2016 (Figure 11; see Appendix B for ADCP configuration files). Global Positioning System (GPS) coordinates were collected at each of the ADCP deployment locations (Appendix B). The ADCPs were mounted in an upward-profiling orientation within an aluminum bottom mount frame (Figure 11), with the nearshore ADCP deployed in approximately $3.7 \mathrm{~m}$ of water and the offshore ADCP in approximately $7 \mathrm{~m}$ of water. The manufacturer's stated accuracy of the TRDI $1200 \mathrm{kHz}$ Workhorse Sentinel ADCP pressure sensor is $\pm 0.25 \%$, and the velocity measurement accuracy (standard deviation of measurement bias) ranges from \pm 0.24 to \pm 1.93 centimeters per second based on the vertical resolution of the measurement bins (0.25 $\mathrm{m}$ to $2.0 \mathrm{~m}$, respectively). 
Figure 11. Upward looking ADCP and mount prior to deployment.

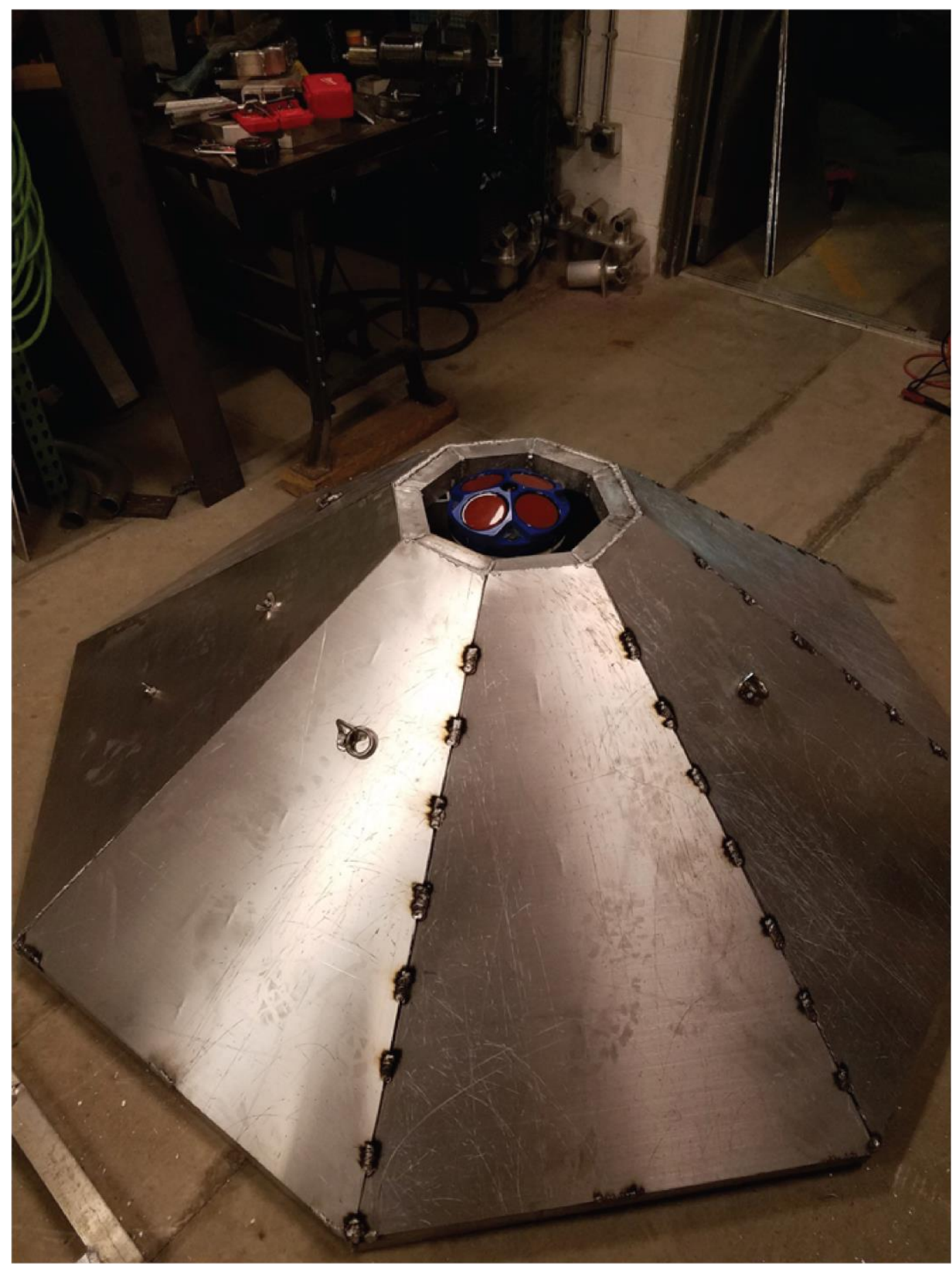

Both ADCPs were programmed to collect a vertical water velocity profile at 20-minute intervals, in which each velocity profile consisted of an average of 15 pings collected at 2 hertz $(\mathrm{Hz})$, with a bin size of $0.2 \mathrm{~m}$. Additionally, each ADCP recorded a burst of water velocity profiles and pressure (at the depth of the ADCP) every 60 minutes. Each burst contains 1200 samples 
collected at $2 \mathrm{~Hz}$. Recovery of the two upward-profiling ADCPs was attempted on 10/28/2016. The nearshore ADCP was successfully recovered; however, the offshore ADCP was buried in sediment, and the recorded data could not be recovered, possibly due to the activities of the unexpected NIPSCO dredge.

\subsection{Survey data}

Three instruments were used to collect bathymetric data in the study area. The portion of the study area surveyed with each instrument depended on the water depth. A Norbit iWBMSc Wideband MBES was used to collect high-resolution bathymetric data in water deeper than approximately $3.7 \mathrm{~m}$. The manufacturers stated accuracy of the MBES system is $0.02-$ $0.1 \mathrm{~m}$. Two bathymetric surveys were collected using the Norbit MBES deployed from a manned boat (Table 3). This MBES is capable of collecting bathymetric data from 256 beams over a 7-degree to 210-degree swath and is integrated with an Inertial Navigation System (INS). The INS includes two Novatel Global Navigation Satellite System receivers for navigation, an inertial motion unit that measures heave, pitch, roll, and heading, and a controller/processor. A cellular network link to a continuously operating reference station established and maintained by the Indiana Department of Transportation (http://incors.in.gov/rtk.aspx) was used to provide the real-time kinematic differential corrections to the INS for the navigation and tide solution during the survey. Depth data from the MBES and the position/attitude data from the INS were displayed in realtime during the survey and logged for additional post-processing in HYPACK/HYSWEEP software (Xylem Inc., Rye Brook, NY).

A TRDI $1200 \mathrm{kHz}$ Workhorse Rio Grande ADCP with integrated GPS was used to collect bathymetric data in water ranging from approximately $1.2 \mathrm{~m}$ to $7.6 \mathrm{~m}$ of depth. The manufacturer stated accuracy for the depth measurement of an TRDI $1200 \mathrm{kHz}$ Workhorse Rio Grande ADCP system is $\pm 1 \mathrm{~cm}$ (Teledyne Marine 2013), though miscalibration or errors in the integrated GPS may cause the observed errors to be greater. The TRDI ADCP was deployed from a manned boat for five bathymetric surveys (Table 3). ADCP data were collected using WinRiver II software along four shore-parallel survey lines spaced by approximately $91 \mathrm{~m}$, and 51 crossshore survey lines spaced by approximately $76.2 \mathrm{~m}$ (Figure 10). The WinRiver II ADCP test and compass calibration/evaluation were executed successfully prior to each survey. The WinRiver II software continuously 
logs the depth returns from each beam, the positional data from the GPS, and the pitch, roll, and heading of the instrument.

A backpack-mounted Trimble Ag132 RTK-dGPS was used for the two beach surveys (Figure 12 and Table 3). The Trimble Ag132 RTK-dGPS system has a manufacturer stated accuracy of $<1 \mathrm{~m}$. This RTK-dGPS was used along the subaerially exposed portion of the beach and in water less than $1 \mathrm{~m}$ deep.

Figure 12. Sub-aerial beach and shallow water bathymetry surveys with the backpack-mounted Trimble Ag132 GPS.

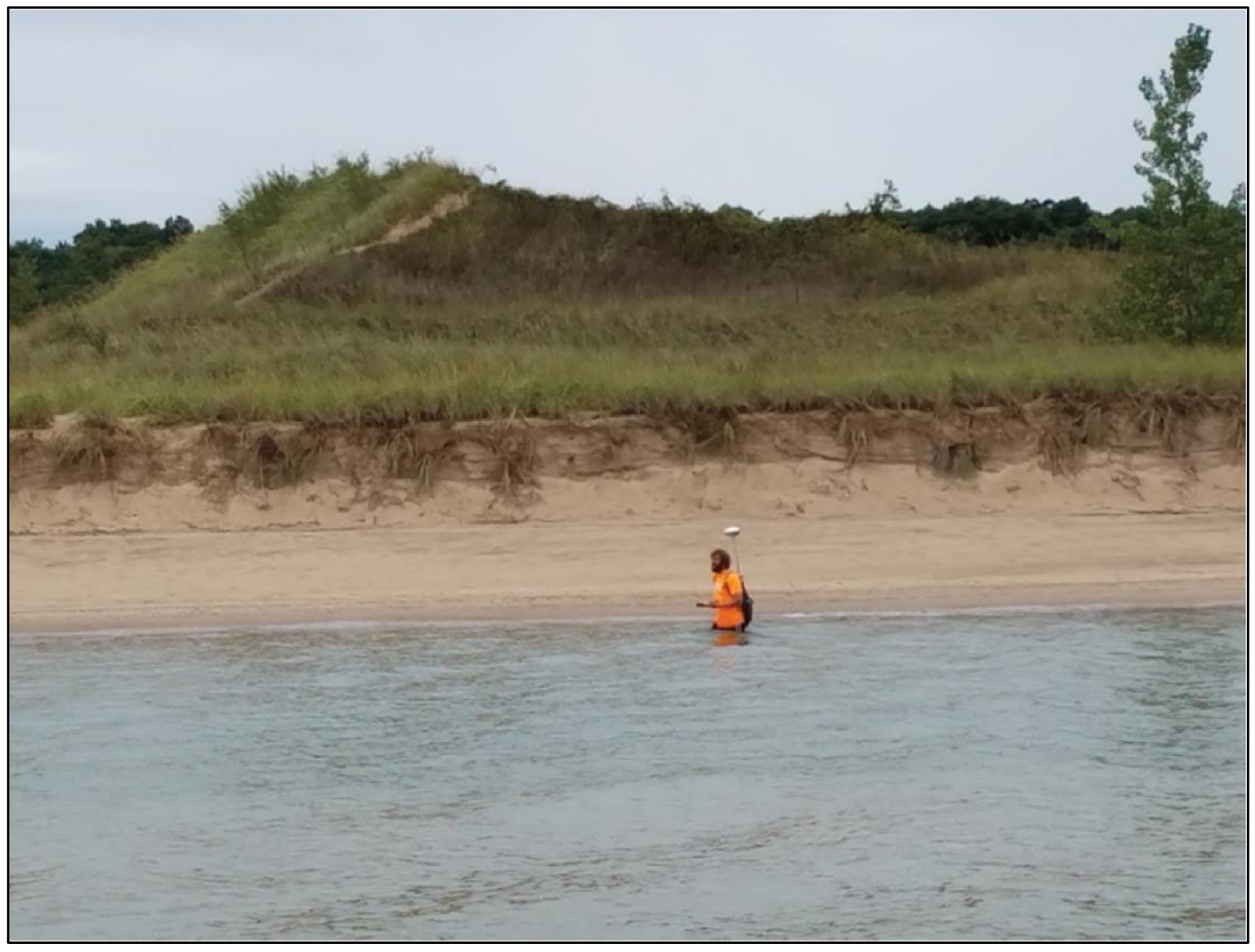


Figure 13. Dredging barge for NIPSCO working in the study area during the $9 / 8 / 2016$ bathymetry survey.

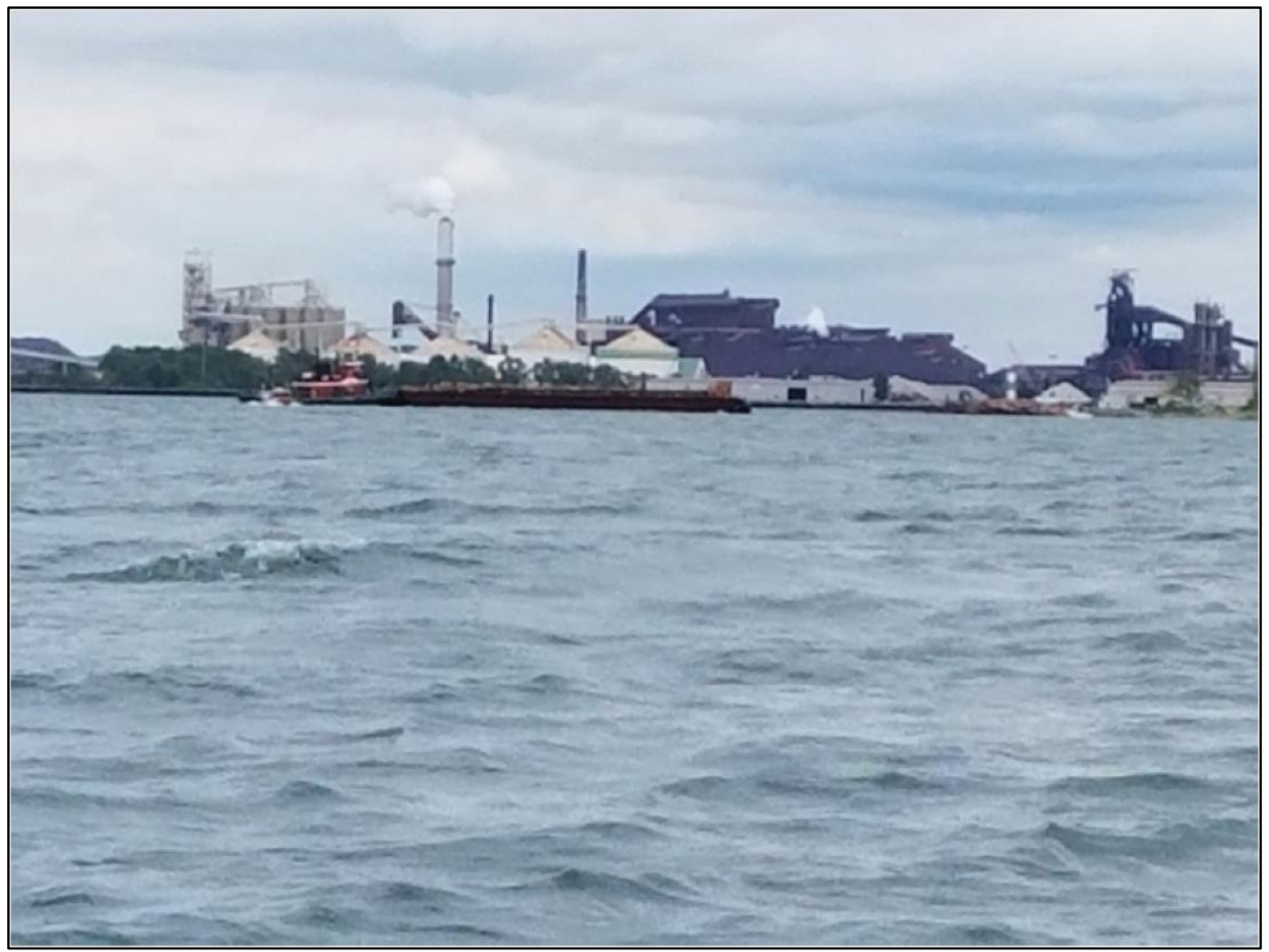




\section{Numerical Modeling at Ogden Dunes}

Hydrodynamic, wave, and sediment transport modeling for Ogden Dunes was conducted using the CMS. The CMS is an integrated suite of numerical models, consisting of a hydrodynamic and sediment transport model, CMSFlow, and a spectral wave transformation model, CMS-Wave (Sanchez et al. 2011a,b). The coupled modeling system calculates time-dependent watersurface elevation, current, waves, sediment transport, and morphology change in coastal ocean, estuarine, and lacustrine environments.

CMS-Flow is a two-dimensional (2-D) finite-volume model that solves the mass conservation and shallow-water momentum equations of water motion on a non-uniform Cartesian grid (Sanchez et al. 2011a,b). Wave radiation stresses and wave parameters calculated by CMS-Wave were supplied to CMS-Flow for the flow and sediment transport calculations.

CMS-Wave is a 2-D spectral wave transformation model that solves the steady-state wave-action balance equation on a non-uniform Cartesian grid (Lin et al. 2008). The model is designed to simulate wave processes that are impactful in coastal zones, in the vicinity of jetties and breakwaters, and in ports and harbors. These processes include wave shoaling, refraction, diffraction, reflection, wave breaking and dissipation, wave-structure and wave-current interactions, and wave generation and growth mechanisms. Water level, current, and morphology changes calculated by CMS-Flow are provided to CMS-Wave at user-specified intervals to complete the coupling between CMS-Flow and CMS-Wave, which are operated through the Surface-Water Modeling System (Aquaveo 2010). The framework of CMS is shown in Figure 14.

For this application, the CMS was driven by water levels, winds, and waves. The current and wave conditions were calculated to investigate sediment movement around the nearshore area of Ogden Dunes. 
Figure 14. The CMS framework and its components (Aquaveo 2010).

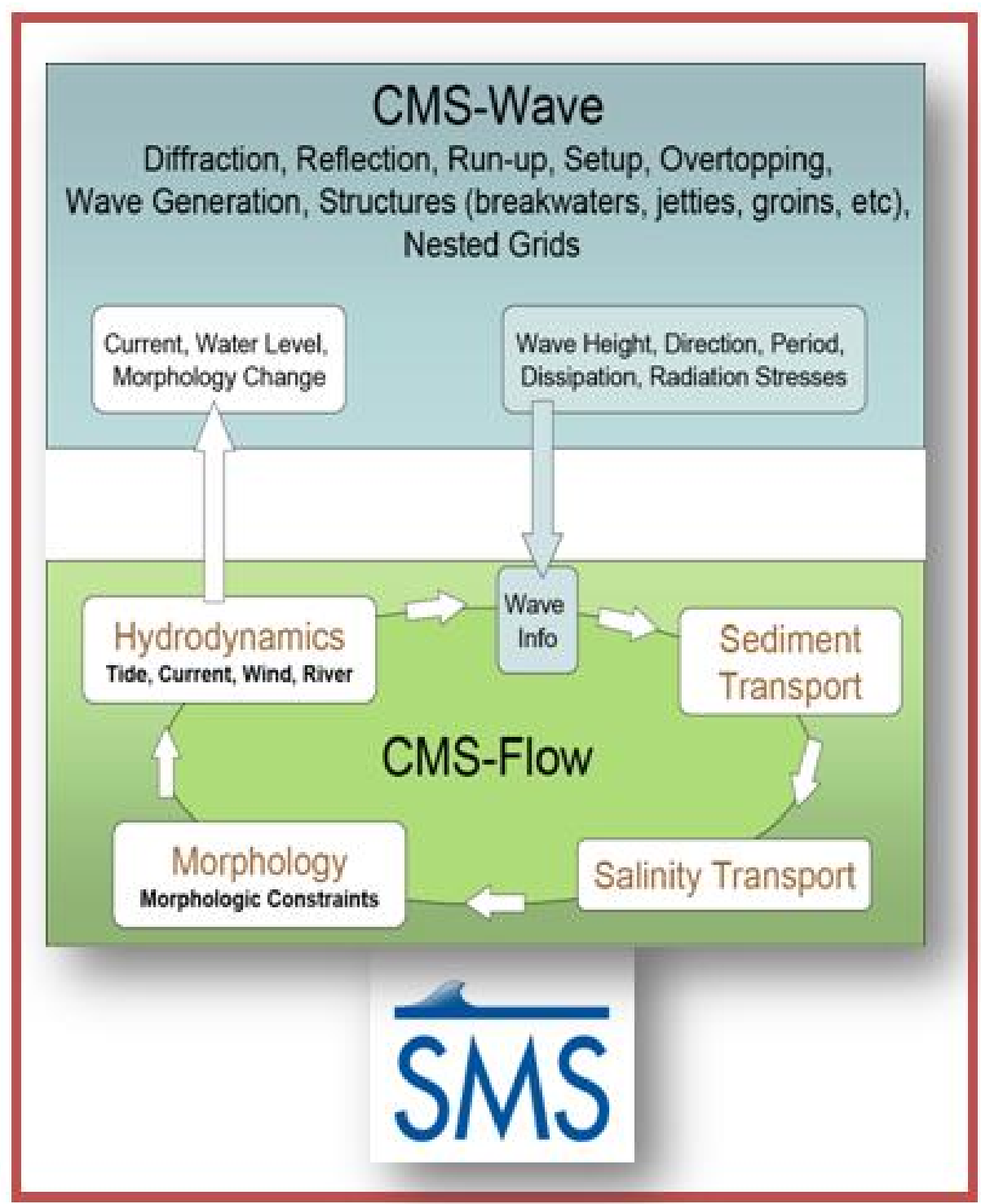

\subsection{Model setup}

CMS-Flow domain was discretized by a telescoping grid (a rectangular grid with variable grid size), which was $15.4 \mathrm{~km}$ in length along the shore and $10.6 \mathrm{~km}$ in width across the shore. The telescoping grid has approximately 80,000 lake cells. The fine resolution cells with $10 \mathrm{~m}$ spacing are specified around the beach front and the nearshore area of Ogden Dunes and the coarse resolution with $320 \mathrm{~m}$ spacing in the offshore area. The average water depth was $2 \mathrm{~m}$ nearshore and increased to $20 \mathrm{~m}$ in the CMS offshore boundary (Figure 15). The time-step for the CMS-Flow simulations was 10 minutes. 
Figure 15. CMS domain, CMS-Flow telescoping grid and bathymetry.

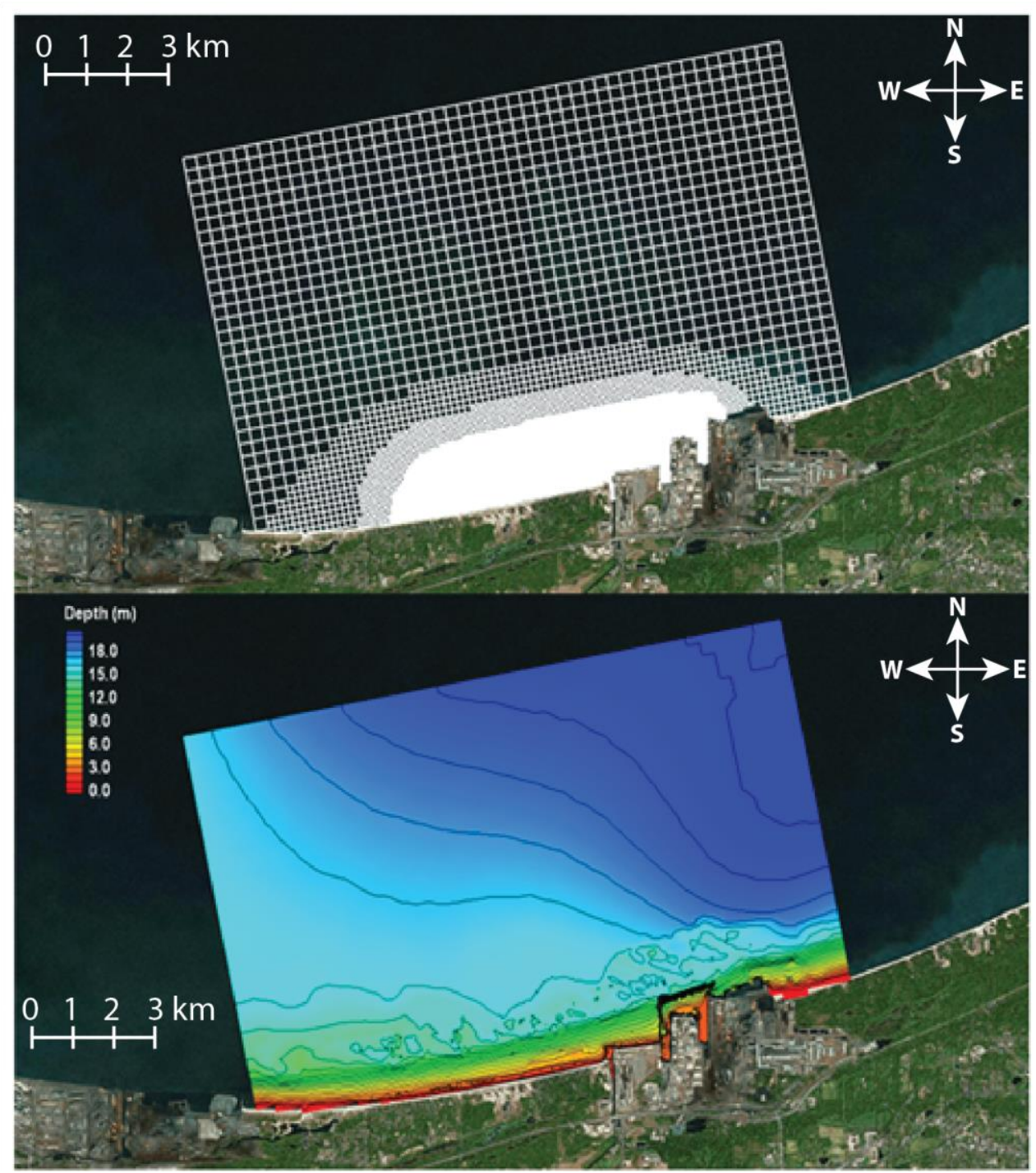

The bounds of the CMS-Wave domain are within the CMS-Flow domain with a horizontal scale of $11.5 \times 7.4 \mathrm{~km}$ (Figure 16). A non-uniform rectangular grid is used for the wave model. Similar to the discretization of the flow model, high-resolution grids of $10.0 \times 10.0 \mathrm{~m}$ are specified nearshore, and grid cell sizes increase to $180 \mathrm{~m}$ away from the lake shoreline. The time-step for the CMS-Wave simulations was 2 hours. Note that the CMS-Flow and CMS-Wave grids are not identical. Also, the dense yellow bands in Figure 16 are areas of interest (e.g., swash zone, placement site, or structures) that require a higher-resolution grid. 
Figure 16. Non-uniform rectangular CMS-Wave grid and bathymetry. The CMS-Flow domain is outlined by the white rectangle.

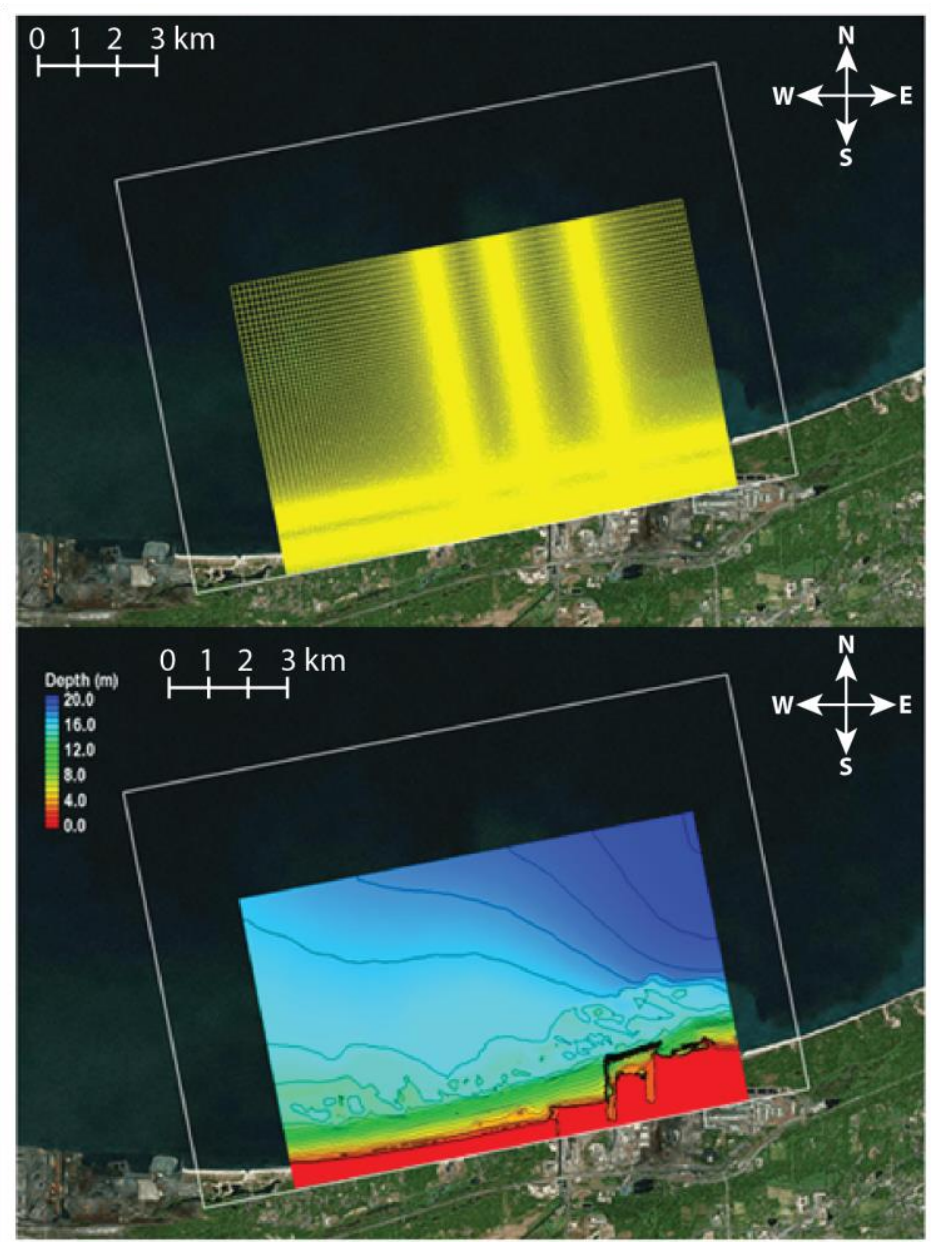

\subsection{Data and model forcing}

Coastline data were based on the Google Earth images, and bathymetry data were extracted from two datasets of the National Geophysical Data Center Coastal DEMs (NOAA 2006). The first dataset covers the entire Lake Michigan with a 3 -arc second spatial (approximately $70 \mathrm{~m}$ ) resolution; the second dataset has a $2 \mathrm{~m}$ spatial resolution and covers the shoreline area of southern Lake Michigan (Figure 17). As part of this study, United States Geologic Survey (USGS) conducted ADCP and MBES bathymetric and beach topographic surveys at Ogden Dunes from June to November 2016 (Duncker et al., 2017). Those data were also incorporated in the numerical model for sediment transport and morphology change calculations. Figure 18 shows the temporal evolution of the survey data in meters relative to Lake Michigan Low Water Datum. 
Figure 17. DEM dataset coverage around the study area. The CMS-Flow domain is outlined by the white rectangle. Note that DEM is finer in the nearshore region.

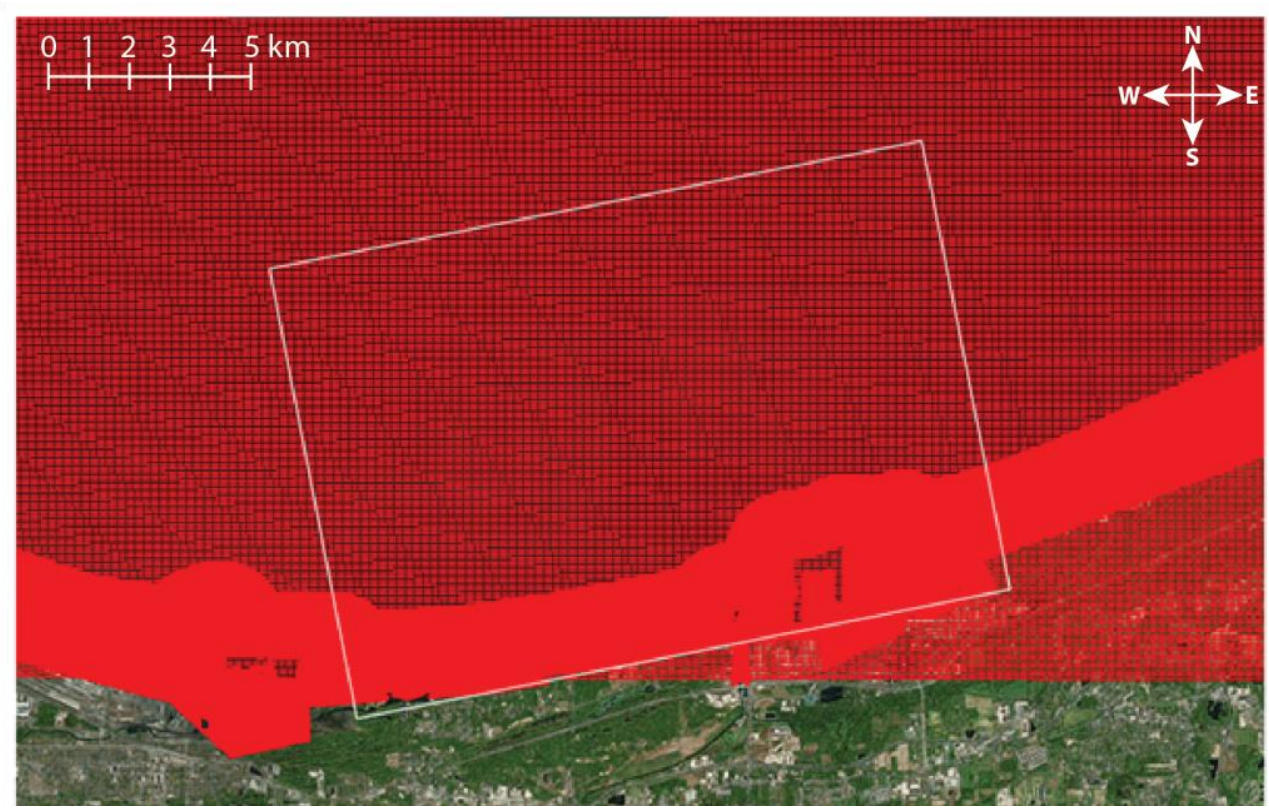

Figure 18. The bathymetric contours of ADCP and MBES survey data from June to November 2016.

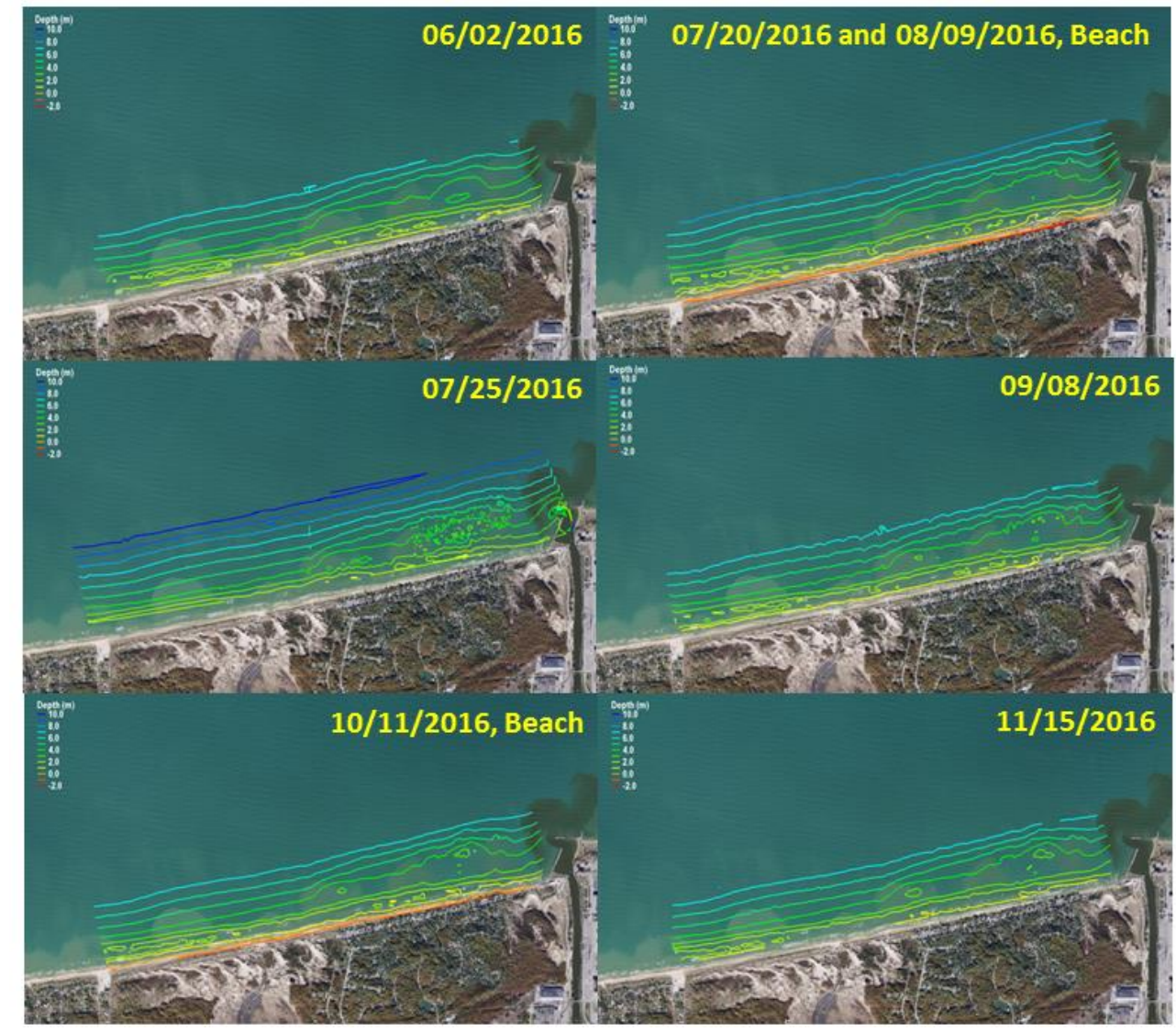


The ADCP dataset of waves, currents, and water-surface elevation were collected from 6/2/2016 to 10/11/2016. The last dredge placement was the unplanned NIPSCO placement performed in September 2016 and followed by three post-placement topographic and bathymetric surveys. Therefore, wave and hydrodynamic simulations were conducted for a period from $7 / 20 / 2016$ to $8 / 31 / 2016$, and with sediment transport calculations from 10/10/2016 to 11/20/2016. CMS-Flow was driven with time-dependent water levels, winds, and waves. Water level data were obtained from National Oceanic and Atmospheric Administration (NOAA) Lake Michigan station (9087044) at Calumet Harbor, Illinois (NOAA 2013, Figure 19). Figure 20 shows hourly water surface elevations for the two simulation periods. The first simulation period corresponded to small variability with water surface elevation fluctuating within the $0.2 \mathrm{~m}$ range. Large fluctuation in water level appeared during the second simulation period, and the water level ranged from -0.4 to $0.2 \mathrm{~m}$.

Figure 19. Locations of Lake Michigan water level gauge 9087044 (Calumet Harbor, Illinois), NOAA buoy 45007 and the up-looking ADCP (BHSH001) site. The white rectangle designates the CMS domain.

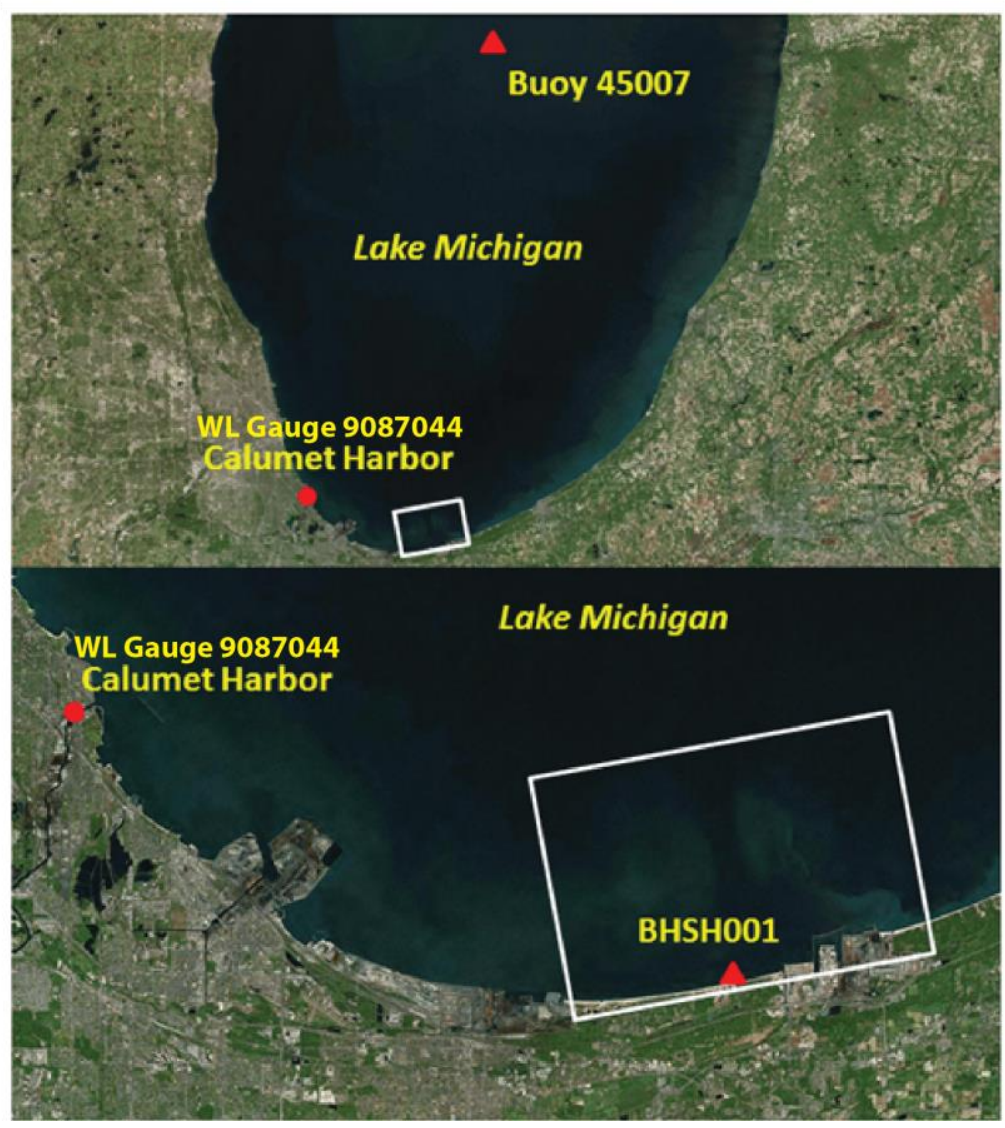


Figure 20. Water level data at Calumet Harbor gauge (9087044) for $7 / 20 / 2016$ to $8 / 31 / 2016$, and $10 / 10 / 2016$ to $11 / 20 / 2016$.

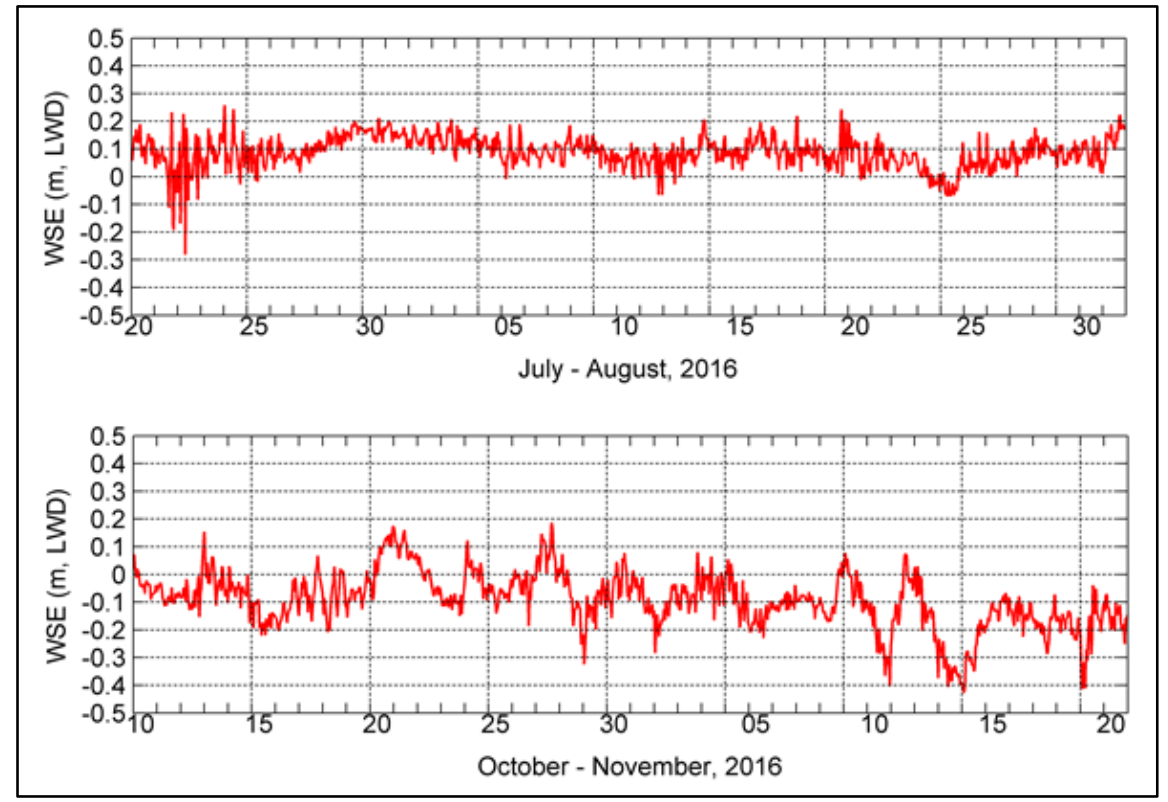

Wind data were obtained from the National Data Buoy Center (NOAANDBC 2017) Buoy 45007, located approximately $120 \mathrm{~km}$ north of Ogden Dunes (Figure 19). Figure 21 and Figure 22 show wind roses and wind speed and direction time series for the summer and the fall periods, which correspond to distinct seasonal wind patterns. The summer period is relatively calm at the offshore buoy site. The mean wind speed was 4.6 $\mathrm{m} / \mathrm{s}$, and the dominant wind direction was from the south. The fall period was characterized by alternate southerly and northerly winds, and the mean wind speed was $7.4 \mathrm{~m} / \mathrm{s}$.

Figure 21. Wind roses for $7 / 20 / 2016$ to $8 / 31 / 2016$ and $10 / 10 / 2016$ to 11/20/2016 at NDBC Buoy 45007.

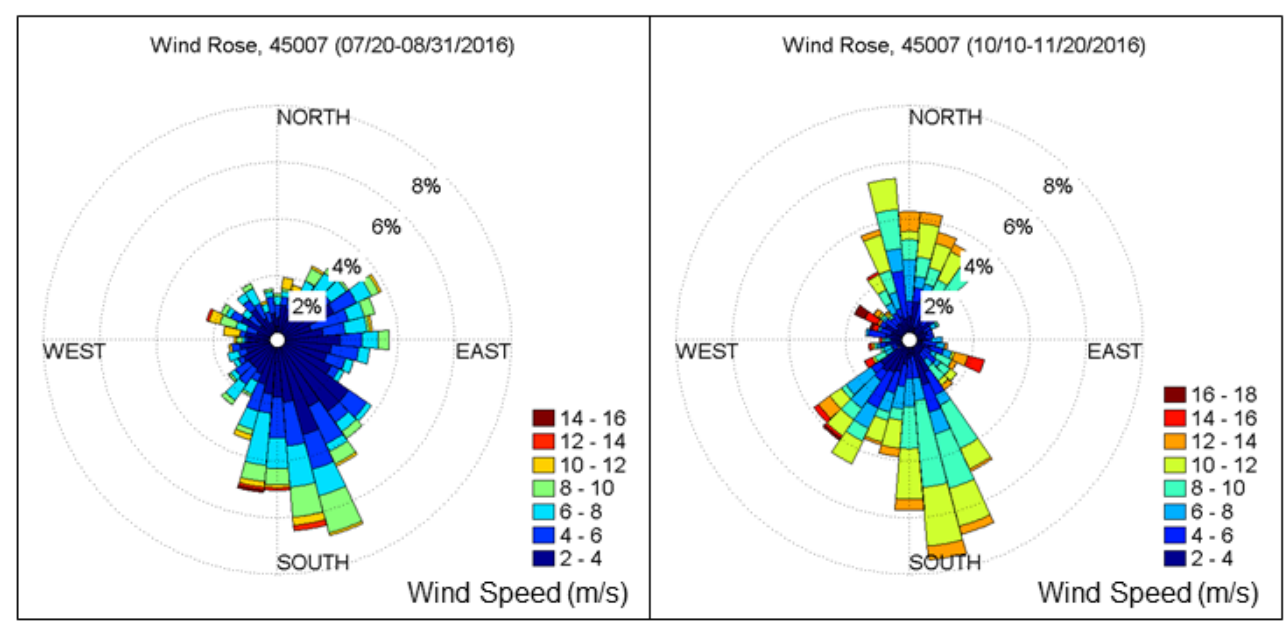


Figure 22. Wind speeds and directions for $7 / 20 / 2016$ to $8 / 31 / 2016$, and 10/10/2016 to 11/20/2016, at NDBC Buoy 45007.

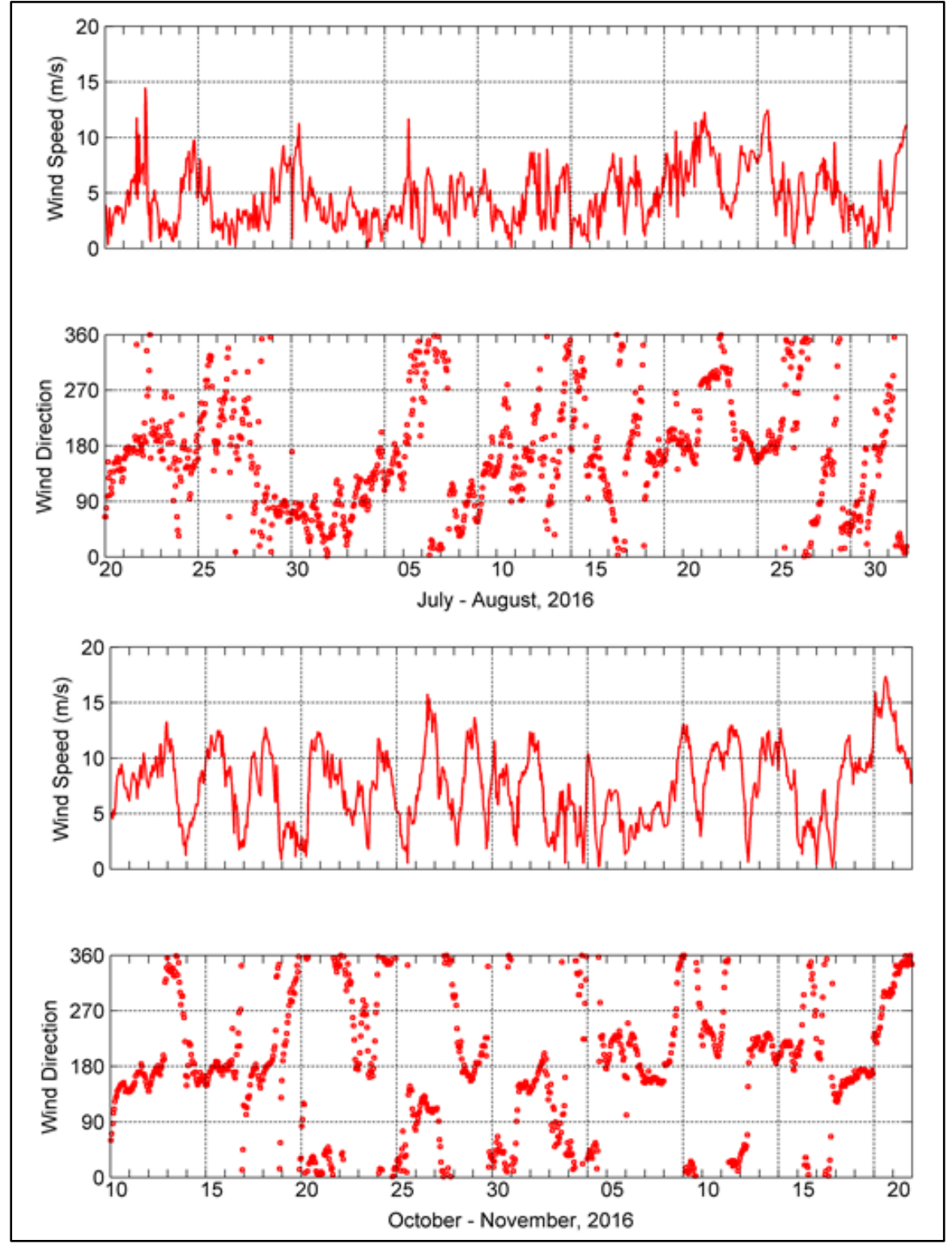

Incident wave conditions were based on directional wave data collected at NDBC Buoy 45007. The buoy wave data were transformed to the seaward boundary of the CMS-Wave grid using a simplified wave transformation for shore-parallel depth contours. Wave roses and wave parameters (significant wave height, peak wave period, and wave direction) are shown in Figure 23 and Figure 24 for the summer and the fall periods. The mean significant wave height (mean wave height of the highest third of the waves observed) was $0.4 \mathrm{~m} / \mathrm{s}$ during the summer period. Larger waves propagated from south-southeast and smaller waves from northnortheast. During the fall period, the dominant wave direction was from 
south-southeast, and large waves with significant wave heights greater than 2. o m primarily propagated from the northeast. The fall period had a mean significant wave height of $1.0 \mathrm{~m} / \mathrm{s}$. The same wind data described above were also used as atmospheric input to wave modeling for wind and wave interactions.

Figure 23. Wave roses for $7 / 20 / 2016$ to $8 / 31 / 2016$, and $10 / 10 / 2016$ to 11/20/2016, at NDBC Buoy 45007.

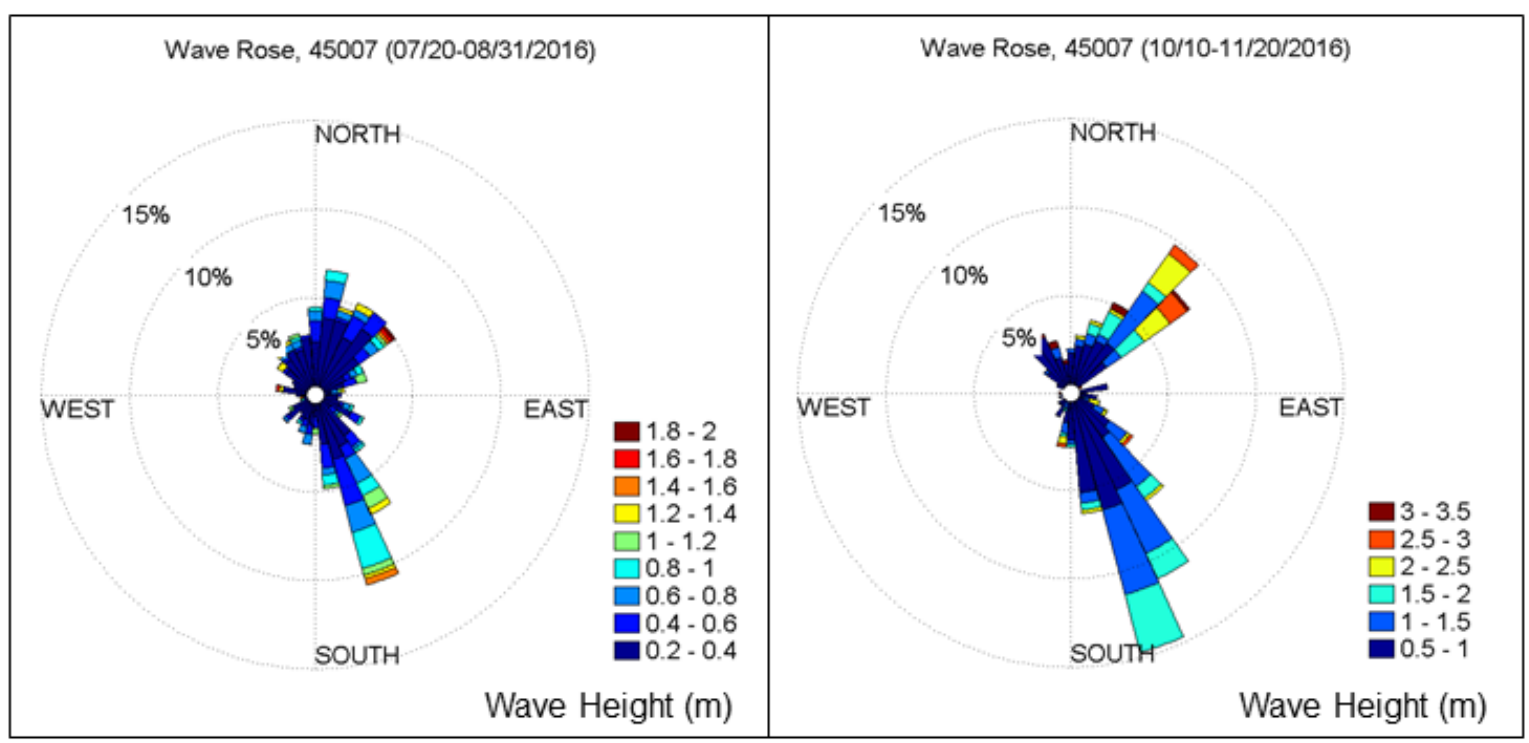

Figure 24. Wave parameters for $7 / 20 / 2016$ to $8 / 31 / 2016$ and $10 / 10 / 2016$ to 11/20/2016 at NDBC Buoy 45007.

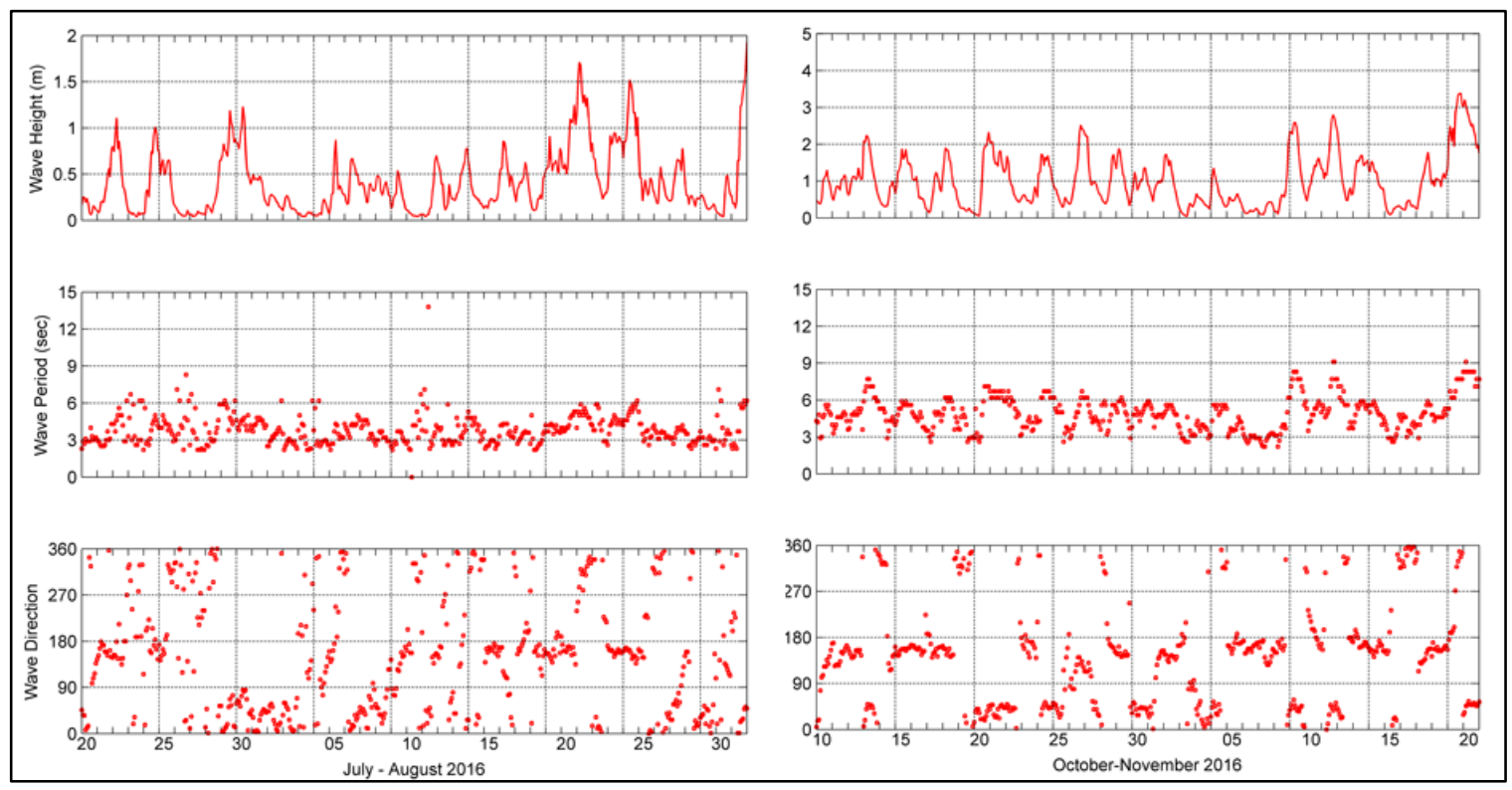


Single-grain size sediment transport was calculated, and the nonequilibrium total load transport model was selected in this study. Table 4 lists selected CMS sediment transport model setup parameters. Additional details on the CMS model setup are given by Sanchez et al. (2011b).

Table 4. CMS sediment transport model setup parameters.

\begin{tabular}{|l|l|}
\hline Parameter & Value \\
\hline Transport formula & VAN_RIJN \\
\hline Median grain size (d50) & $0.15 \mathrm{~mm}$ \\
\hline Bed load scaling factor & 1 \\
\hline Suspended load scaling factor & 1 \\
\hline Total-load adaptation length & $10 \mathrm{~m}$ \\
\hline Morphologic acceleration factor & 1 \\
\hline Bed porosity & 0.4 \\
\hline Bed slope coefficient & 0.1 \\
\hline
\end{tabular}

\subsection{Model results}

\subsubsection{Water surface elevation}

Lake Michigan water surface elevations were calculated at the location corresponding to BHSHoO1 for $7 / 20 / 2016$ to $8 / 30 / 2016$, and 10/10/2016 to $11 / 20 / 2016$. Time series values from the July-August simulation were plotted against the ADCP measurements at BHSHoo1 (Figure 25a). Because the measurements ended on 10/11/2016, only the calculated values from the October-November simulation were examined, which was very similar to the time series plot of water surface elevations at Calumet Harbor as shown in Figure 20. Both the measured data and the calculated results show small water level fluctuations, and the measurements have a maximum water level of $0.25 \mathrm{~m}$ and a minimum of $-0.15 \mathrm{~m}$ during the summer period. The standard deviation of the data and the model results was 0.054 and $0.058 \mathrm{~m}$, respectively. The variations in water levels during the fall period were much larger than those during the summer period, and the standard deviation of the model results was $0.11 \mathrm{~m}$ (no corresponding water level measurements exist for the fall period). Figure 22 and Figure 24 indicate that most of the large water level changes corresponded to large wind/wave conditions. 
Figure 25. (a) Water surface elevation comparisons between the measurements and the CMS calculations and (b) pressure-derived water depth data at the ADCP Station, BHSH001 from 7/20/2016 to 8/30/2016.

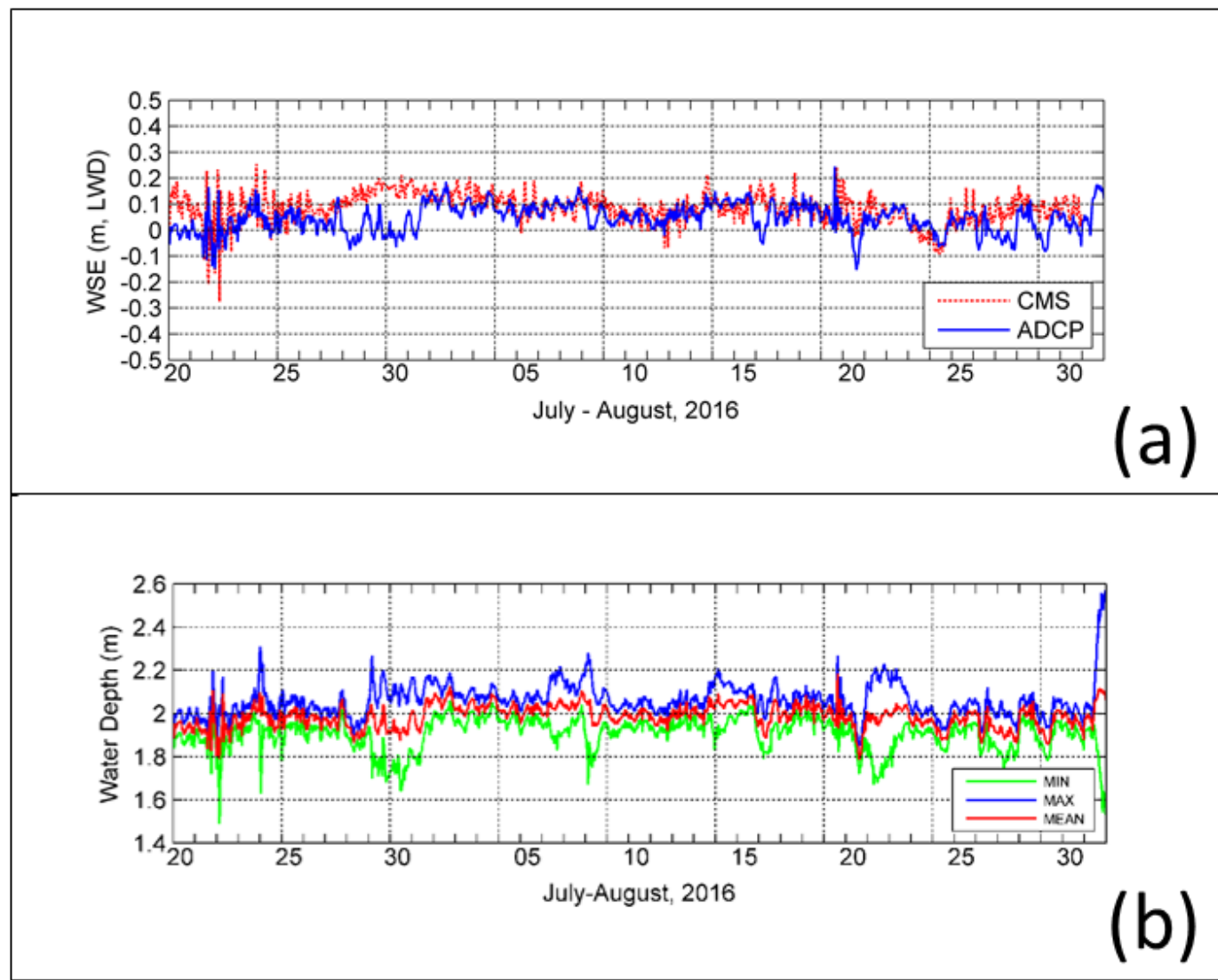

Goodness-of-fit statistics were calculated for the water level comparison between the model $\left(Y_{\text {mod }}\right)$ and data $\left(Y_{o b s}\right)$, which included the calculation of the correlation coefficient (R), Root-Mean-Square Error $(R M S E=$ $\sqrt{\left.\frac{\sum_{i=1}^{n}\left(Y_{m o d}-Y_{o b s}\right)^{2}}{n}\right)}$, and Normalized Root-Mean-Square Error (NRMSE = $\left.\frac{R M S E}{\left(Y_{\text {mod }}-Y_{\text {obs }}\right)}\right)$. During the July-August period, the RMSE was $0.081 \mathrm{~m}$, the NRMSE was 20.4\%, and the correlation coefficient $\mathrm{R}$ was 0.23 . The calculated water level time series matched the measured values somewhat well during the majority of the simulation period (Figure 25a). However, several infrequent but noticeable discrepancies occurred, which were as large as 0.2 to $0.25 \mathrm{~m}$ and could account for the low value of $\mathrm{R}$ and high values of RMSE and NRMSE. To better understand the cause of discrepancies between observations and model predictions, the mechanistic underpinnings of the modeling framework used here were considered as well as the data collection process. 
In a hydrodynamic model simulation, water level calculations are primarily controlled by open boundary input. Therefore, water surface elevations at three water-level gauges surrounding the study area were examined and used to drive the numerical model alternately. All three gauges showed similar water level variations, and the changing boundary input did not improve the comparison results. For in situ measurements, raw pressure sensor (pressure-derived depth) data were inspected. Uncertainty in these measurements could be driven by multiple factors. First, it was found that the ADCP was buried in the bed by approximately $0.66 \mathrm{~m}$ of sediment from the time of deployment to the date of recovery (5/31/2016 to $10 / 28 / 2016)$, which would contribute to errors in measurements. This could be due to a combination of instrument settling and coverage by additional sediment, but the precise contribution from each is unclear from the data available. In addition, each hourly burst of data collection (1024 time steps recorded at $2 \mathrm{~Hz}$ ) was averaged, and the data range was obtained (maximum - minimum values) (Figure 25b). The model and data discrepancies shown in Figure 25(a) are closely associated with periods of large measured data fluctuations in Figure 25(b).

\subsubsection{Currents}

Figure 26 shows the scatter plot of calculated and measured currents and principal current axes at the ADCP station. The principal current direction is approximately parallel to the lake shoreline and represents alongshore flow. The positive values indicate east-northeast current, and the negative values indicate west-southwest current. Relative to north, both the calculated and measured principal current axes have an angle of $73.5^{\circ}$ during the summer simulation period and an angle of $78^{\circ}$ during the fall simulation period. The measured currents display large fluctuations around the principal direction, and the calculated currents flow more uniformly parallel to the shoreline. 
Figure 26. Scatter plots of (a) the calculated and measured currents at the ADCP station, BHSHO01, from $7 / 21 / 2016$ to $8 / 30 / 2016$, and (b) the calculated currents from $10 / 10 / 2016$ to $11 / 20 / 2016$. The blue line indicates the principal current axis, $\mathrm{U}$ is the east-west velocity component, and $\mathrm{V}$ is the north-south velocity component.
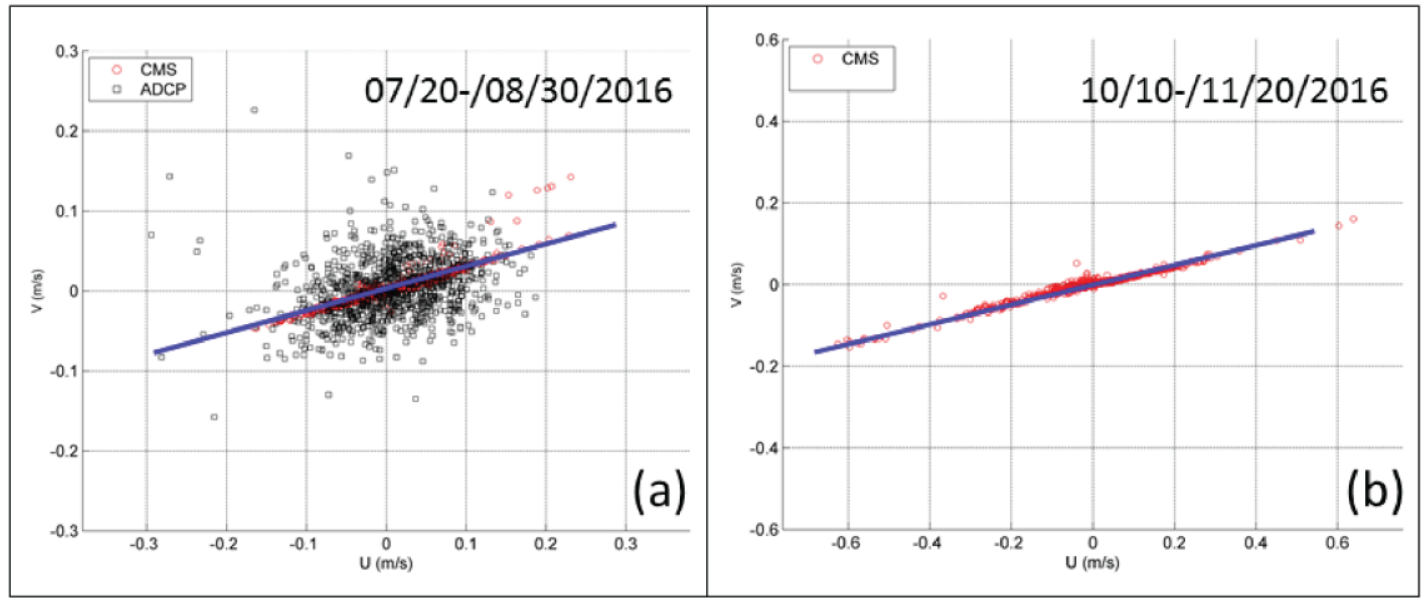

The comparison of calculated and measured time series of current direction is shown in Figure 27. Both the calculations and measurements show a small current speed range within $\pm 0.2 \mathrm{~m} / \mathrm{s}$ (east-northeastward and west-southwestward current) in the along-shore direction during the summer simulation period. The range in the measured alongshore current values during the fall simulation period was as large as $\pm 0.6 \mathrm{~m} / \mathrm{s}$ due to early winter storms (Figure 22). Overall, the calculated principal currents were in fair agreement with the measured currents. Corresponding to the discrepancies in the water level comparison (Figure 25), current phase discrepancies can be seen in Figure 27, which could explain the large RMSE and the NRMSE of $0.08 \mathrm{~m} / \mathrm{s}$ and $18.8 \%$, respectively, as well as the low correlation coefficient of 0.14 . 
Figure 27. (a) Principal current comparisons between the measurements and the CMS calculations at the ADCP station BHSH001, from 7/20/2016 to 8/30/2016, and (b) calculated principal currents from 10/10/2016 to 11/20/2016.

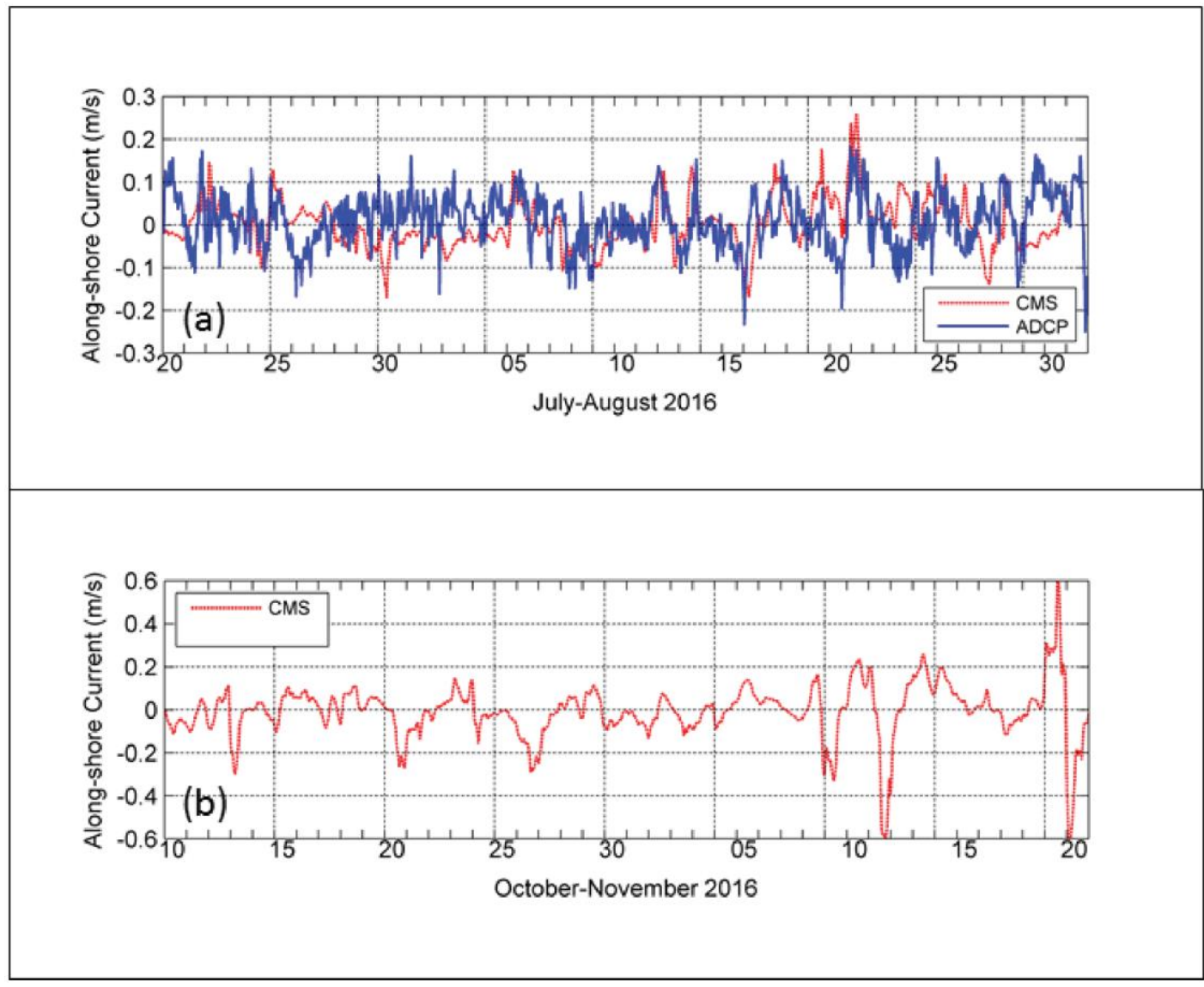

Figure 28 shows a snapshot of the calculated current field on 8/21/2016, at 04:00 Greenwich Mean Time (GMT). The flow field is responding to northwesterly wind with a peak wind speed of approximately $11 \mathrm{~m} / \mathrm{s}$, and the dominant current direction is parallel to the shoreline from southsouthwest to north-northeast. The offshore current speed is less than $0.1 \mathrm{~m} / \mathrm{s}$, and the nearshore surf zone current is between 0.3 and $0.4 \mathrm{~m} / \mathrm{s}$. 
Figure 28. Calculated current field on 8/21/2016, at 04:00 GMT. The red rectangle indicates the nearshore ADCP bathymetry survey area, and the red dot is the location of the ADCP station, BHSHOO1.

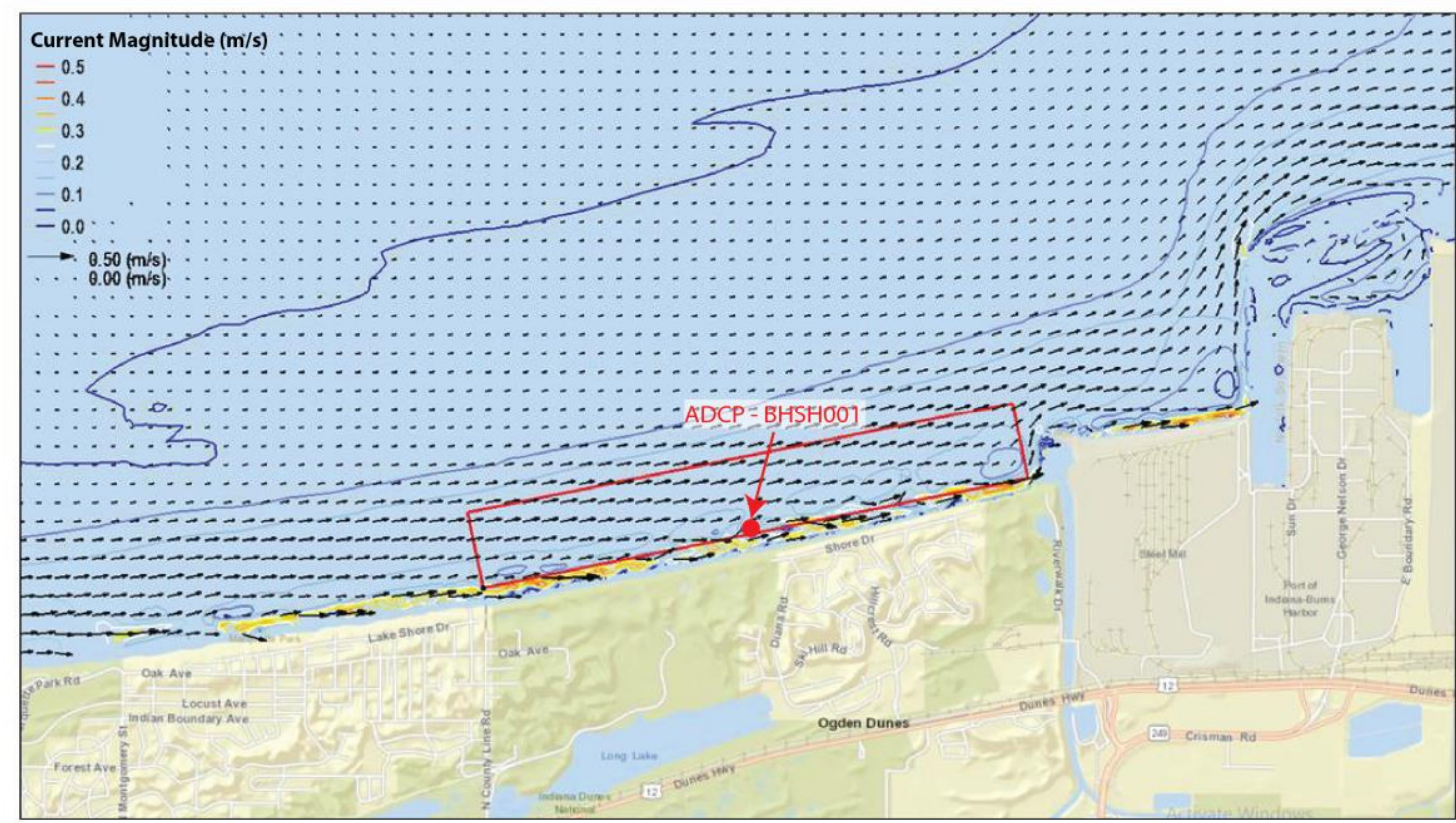

The study area experienced a few early winter storms during the fall simulation period, which induced a stronger longshore current in the model domain. Figure 29 shows another snapshot of the calculated current field on 11/11/2016, at 16:00 GMT. At this time the dominant wind blew from northnortheast, and wind speed was greater than $12 \mathrm{~m} / \mathrm{s}$. Corres-ponding to the wind direction, alongshore current flowed from north-northeast to southsouthwest. The maximum current still appeared in the surf zone area, and the current speed was as high as $0.7 \mathrm{~m} / \mathrm{s}$. 
Figure 29. Calculated current field on 11/11/2016, at 16:00 GMT. The red rectangle indicates the nearshore ADCP bathymetry survey area, and the red dot is the location of the ADCP station, BHSHOO1.

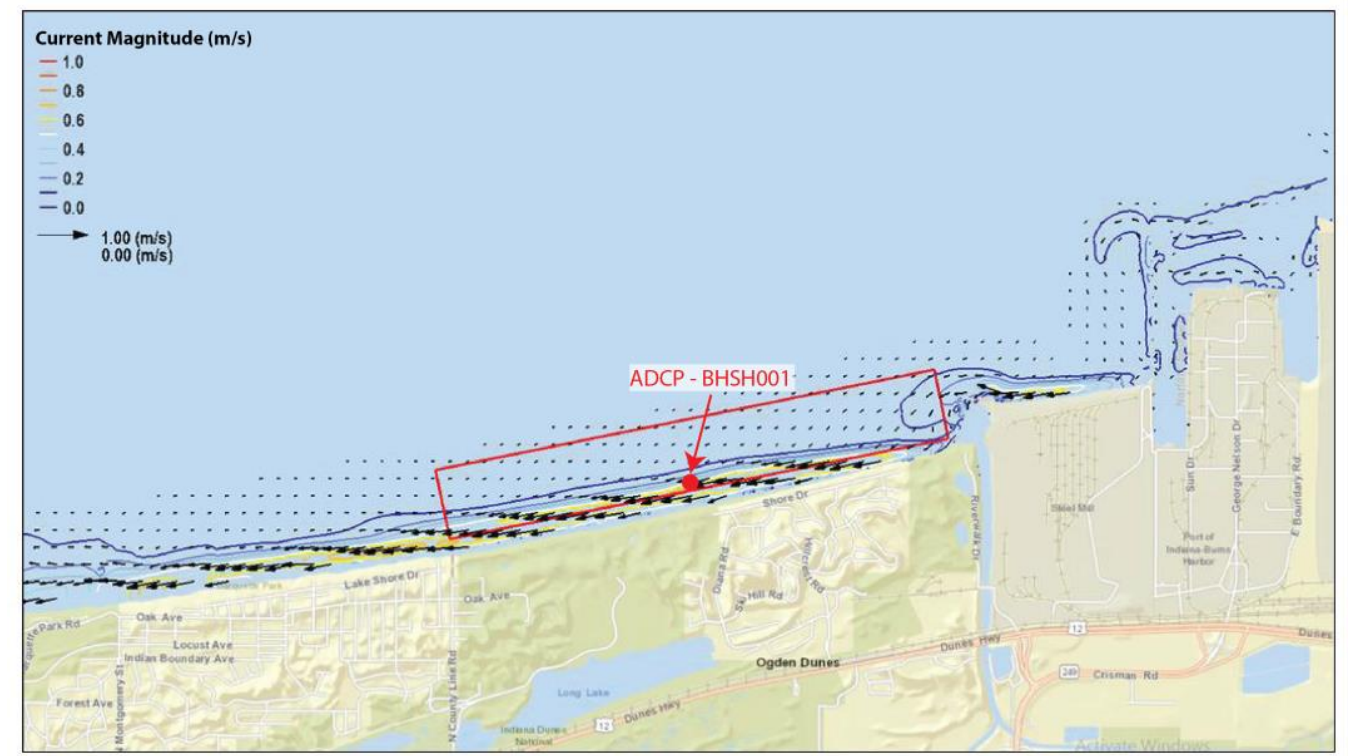

\subsubsection{Waves}

Incident waves that impacted the study area were primarily propagating from the north and were influenced by wind fields, as per Figure 24, which shows the wave parameters for $7 / 20 / 2016$ to $8 / 31 / 2016$, and 10/10/2016 to $11 / 20 / 2016$, at NDBC Buoy 45007. Figure 30 shows the wave parameter comparisons between the measurements and the CMS calculations at the ADCP Station BHSHoo1 from 7/20/2016 to 8/30/2016. From the comparison it can be seen that the model overpredicted significant wave heights. The measurements indicated an average wave height of $0.1 \mathrm{~m}$, and the model calculated an average of $0.14 \mathrm{~m}$ during the summer period. The ADCP measured small long waves with peak wave periods of greater than 5 seconds ( $s$ ), which were not revealed by the calculated results. In the study domain, larger waves propagated from the north. When significant wave heights were greater than 0.1-0.2 m, the calculated wave periods of 4-6 s matched the measured periods fairly well. Significant wave heights greater than $1 \mathrm{~m}$ occurred more often during the fall period. The calculated average significant wave height and peak wave period were $0.4 \mathrm{~m}$ and 3.8 s, respectively. Figure 31 shows the CMS calculated wave parameters at the ADCP location, BHSHoo1 from 10/10/2016 to 11/20/2016, - no validation data are available for this time period due to the BHSHoo1 ADCP data collection concluding on 10/11/2016. 
Figure 30. Wave parameter comparisons between the measurements and the CMS calculations at the ADCP Station, BHSHO01 from 7/20/2016 to 8/30/2016.

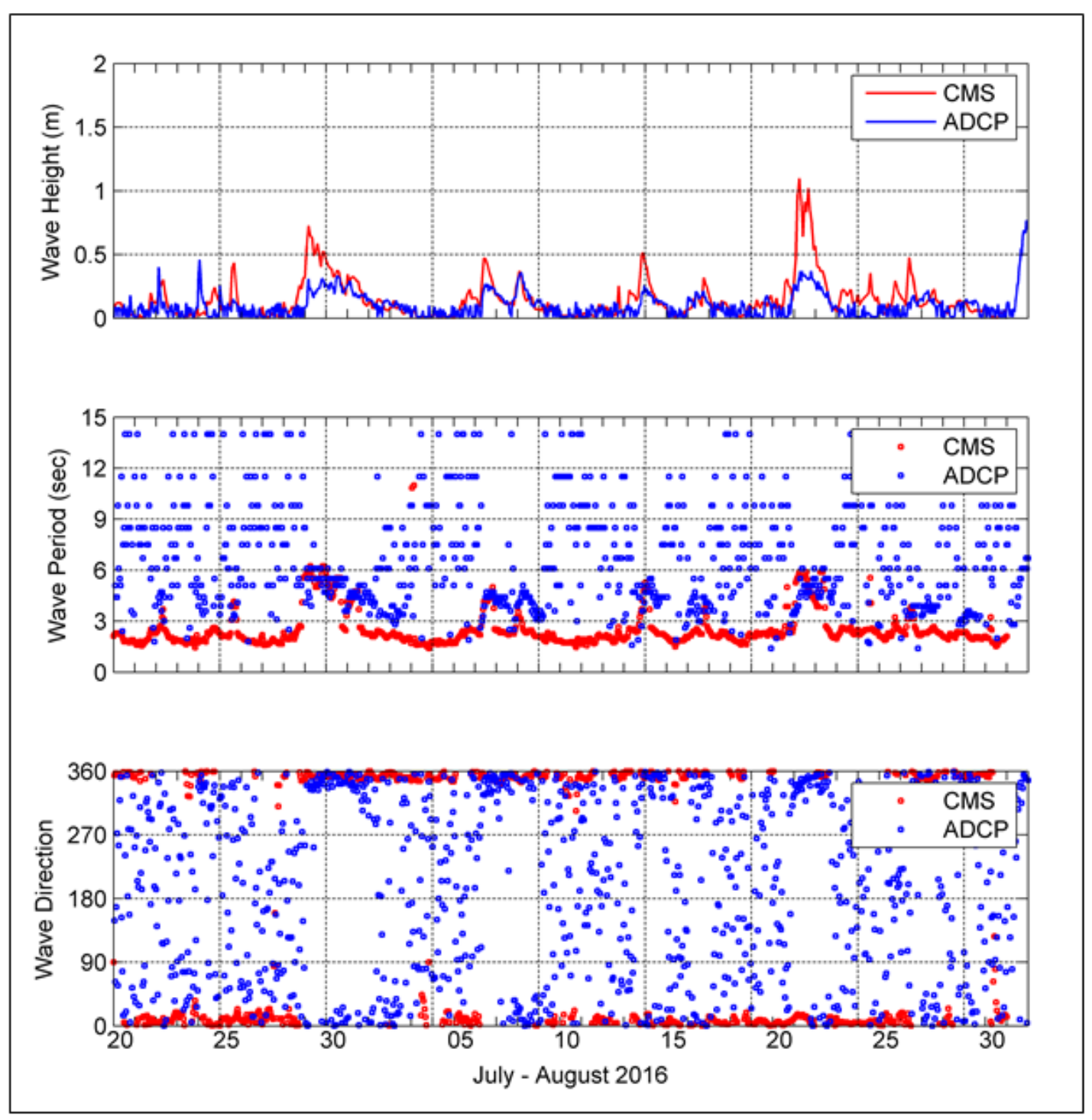


Figure 31. Calculated wave parameters at the ADCP location, BHSH001 from $10 / 10 / 2016$ to $11 / 20 / 2016$.
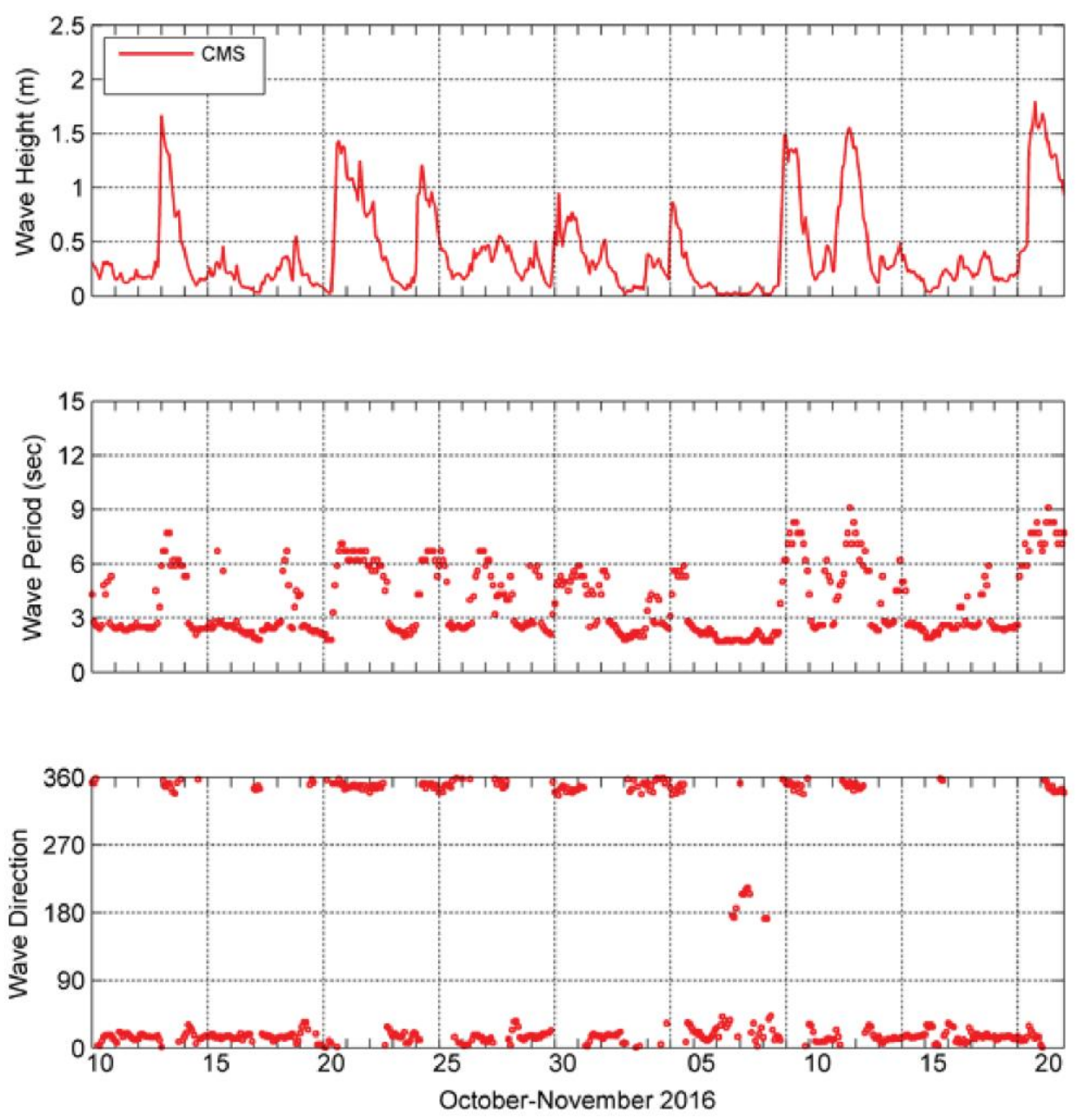

Based on wind fields, two snapshots of calculated wave fields were plotted in Figure 32 and Figure 33 for the summer and the fall periods, respectively, during which wind speeds were approximately $12 \mathrm{~m} / \mathrm{s}$, and wind blew from southwest and north-northeast, respectively. Wave fields show that uniform wave heights cover the deeper portion of the model domain, and waves break upon approaching the lake shoreline. Corresponding to the wind conditions, wave heights were approximately 1.0 $\mathrm{m}$ and $2.0 \mathrm{~m}$ offshore and propagated from northwest and northnortheast. 
Figure 32. Calculated significant wave heights on 8/21/2016 at 04:00 GMT. The red rectangle indicates the nearshore ADCP bathymetry survey area.

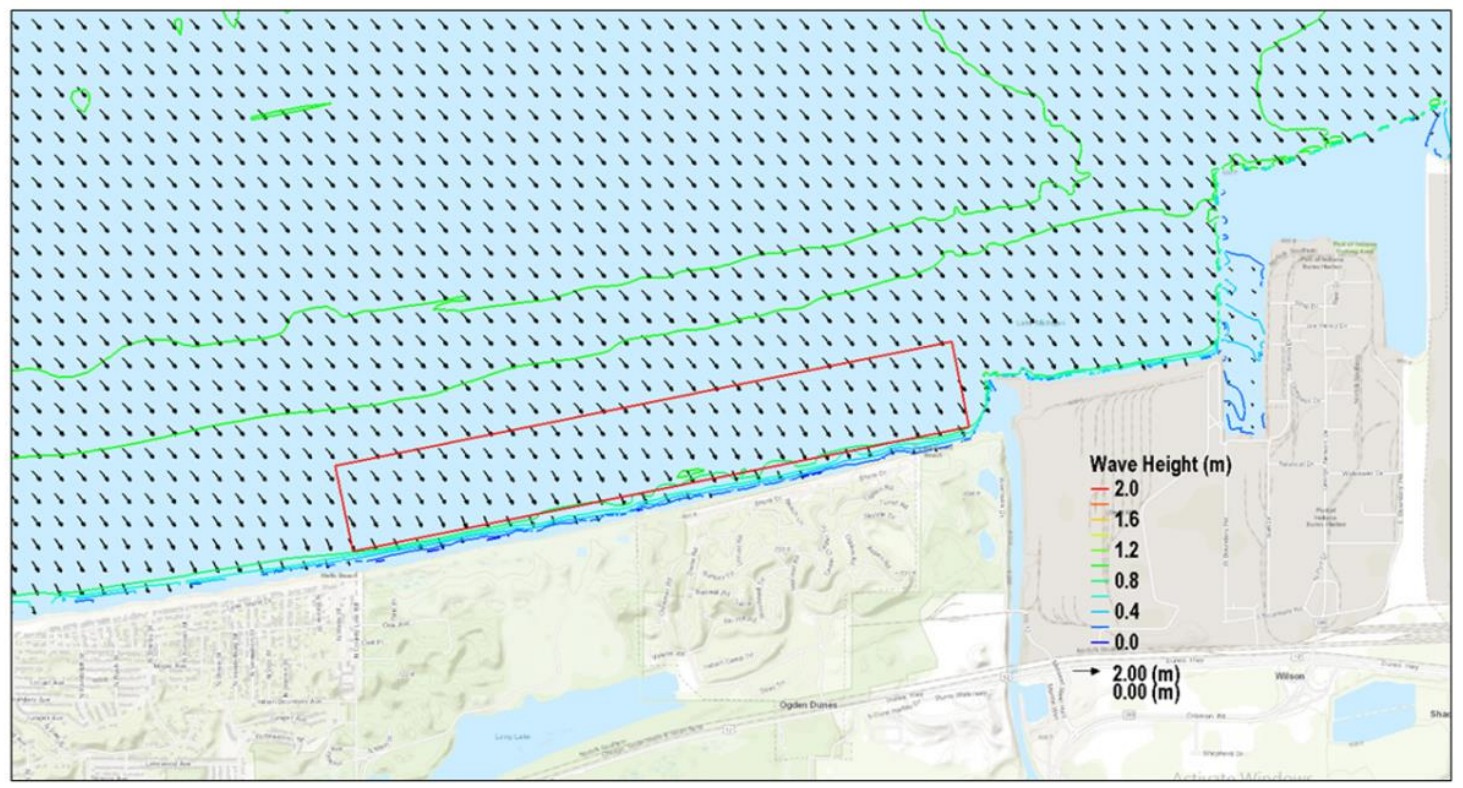

Figure 33. Calculated significant wave heights on 11/11/2016, at 16:00 GMT. The red rectangle indicates the nearshore ADCP bathymetry survey area.

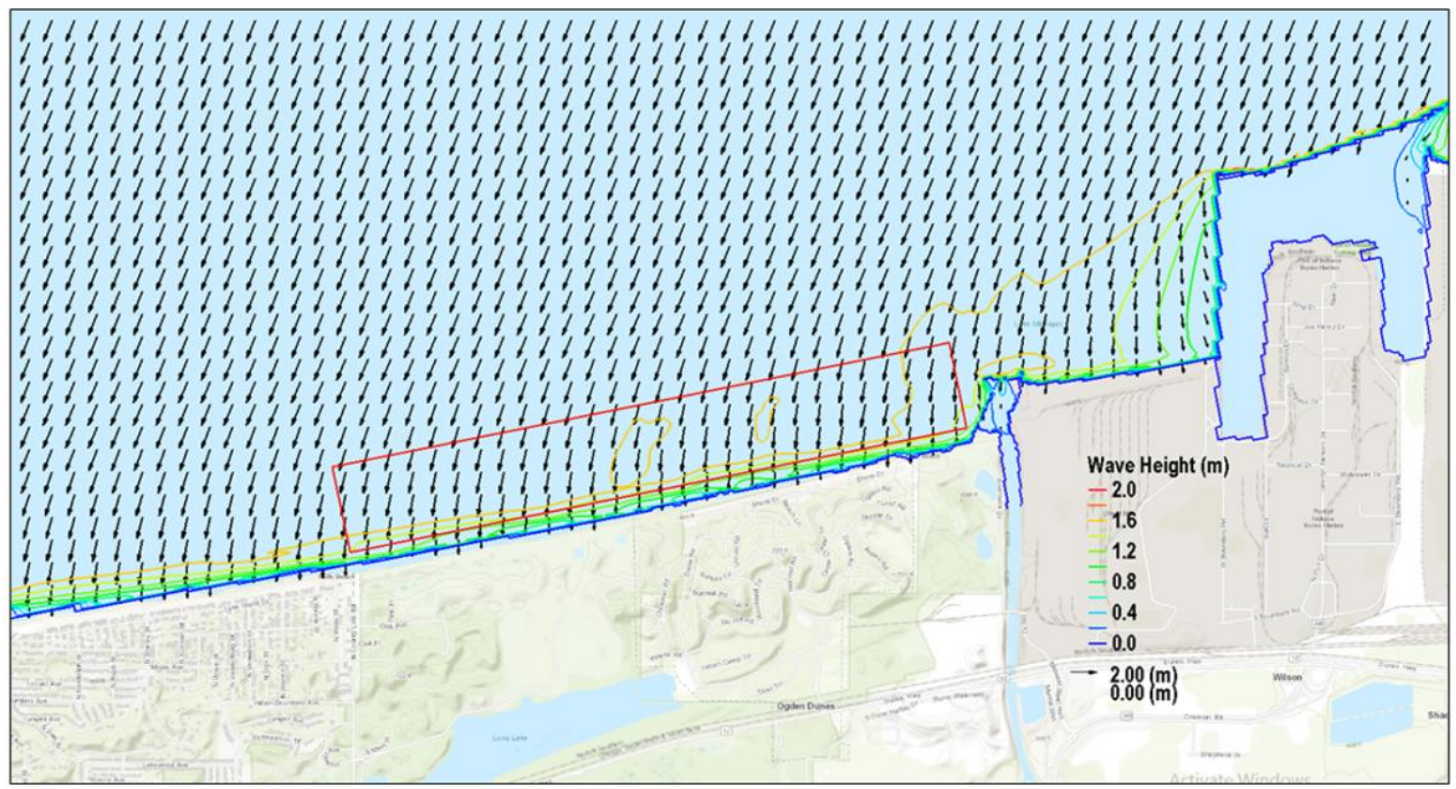

\subsubsection{Sediment transport and morphology change}

The fall simulation from 10/10/2016 to 11/20/2016 was employed to calculate sediment transport and morphology change based on the last two ADCP bathymetry surveys on 10/11/2016 and 11/15/2016. To examine circulation and sediment transport patterns, the model simulation results 
between 10/10/2016 and 11/15/2016, were averaged, and mean current and corresponding sediment transport fields were obtained as shown in Figure 34 and Figure 35, respectively.

Figure 34. Calculated mean current for the period of 10/10/2016 to $11 / 15 / 2016$. The red rectangle indicates the nearshore ADCP bathymetry survey area, and the red dot is the location of the ADCP station, BHSHOO1.

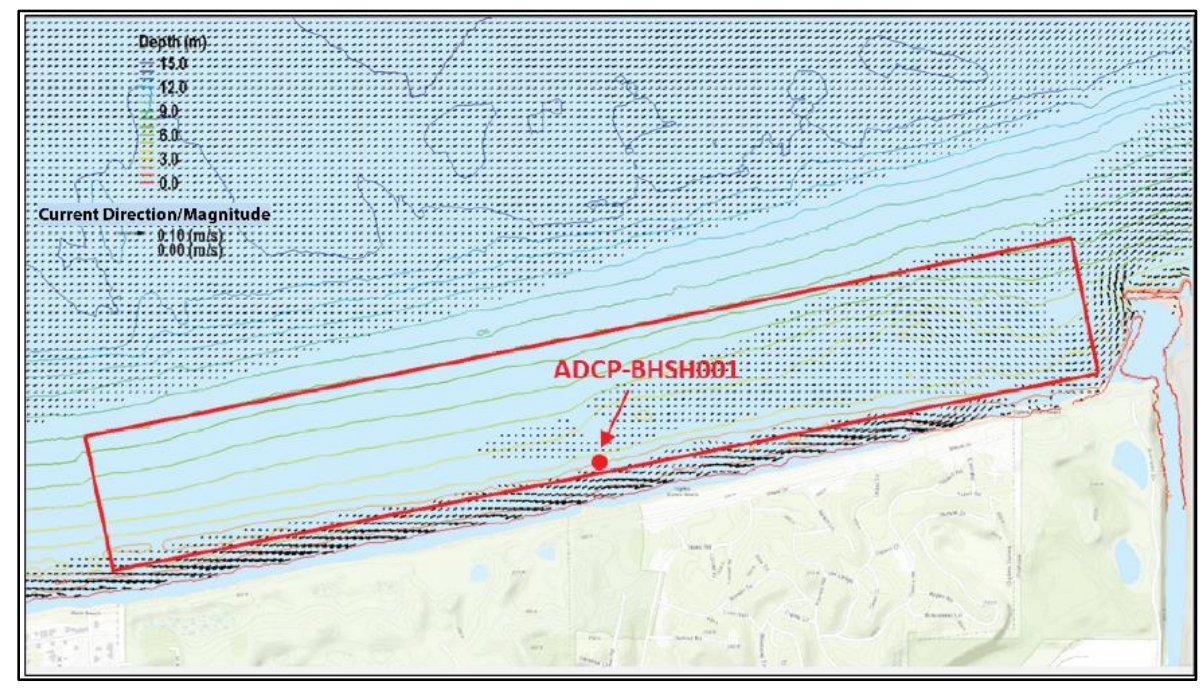

Figure 35. Calculated mean sediment transport for the period of $10 / 10 / 2016$ to $11 / 15 / 2016$. The red rectangle indicates the nearshore ADCP bathymetry survey area, and the red dot is the location of the ADCP station, BHSHOO1.

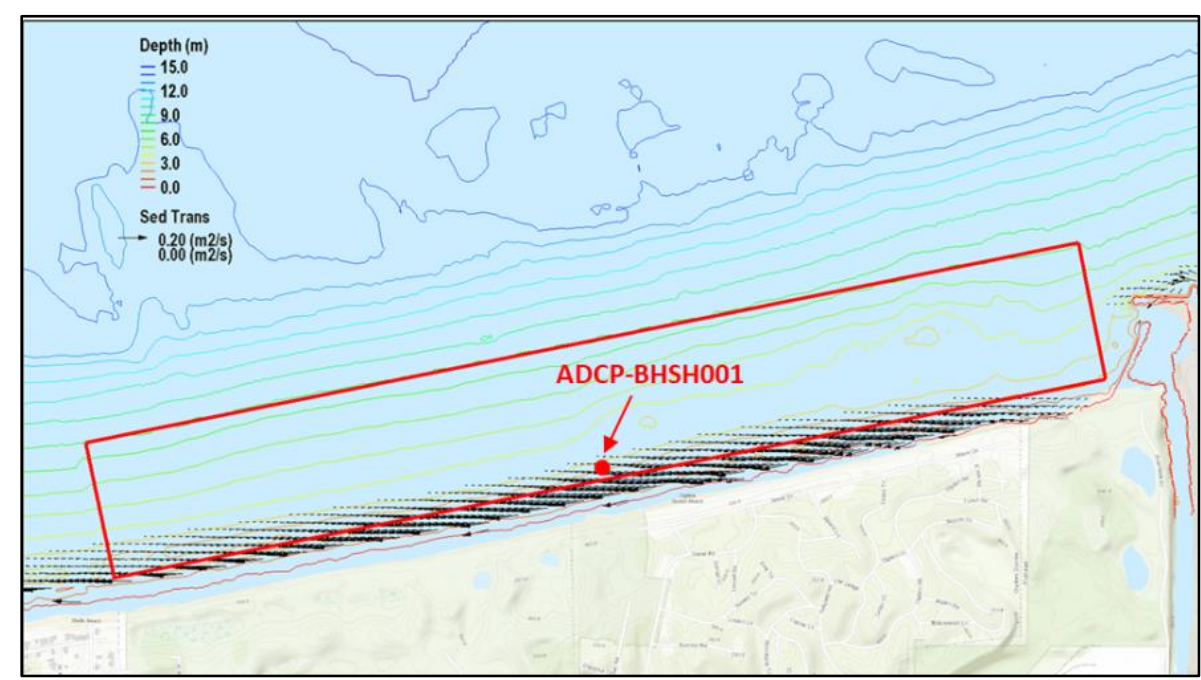

The mean current vectors display dominant, south-southwestward alongshore flows. The maximum current was approximately $0.1 \mathrm{~m} / \mathrm{s}$ in the nearshore area and $0.02 \mathrm{~m} / \mathrm{s}$ in the offshore area. East of the ADCP survey area, a very weak mean current flowed in the opposite direction of the 
alongshore current. The mean sediment transport pattern (Figure 35) corresponded closely with the mean current pattern (Figure 34) and the sediment in the shallow area was transported south-southwestward along the shoreline. The mean alongshore current and sediment movement were driven by dominant, northerly directed storm waves during the simulation period. In general, the calculations indicate that coastal sediments were dominantly transported alongshore towards the south-southwest, and no apparent sediment movement was identified in the deeper lake area.

The ADCP bathymetry surveys were conducted in 50 transects perpendicular to the lake shoreline. A subset including 19 of the 50 surveyed transects is shown in Figure 36, with more dense spacing over the nearshore placement site. The measured and the calculated profiles on 10/11/2016 and 11/15/2016 are shown in Figure 37. Transect 1 survey on 11/15/2016 was missing, and its profile comparison was not included in the figure. For the fall simulation, the 10/11/2016, survey data were incorporated into the NOAA DEM datasets (NOAA 2006) to generate the initial model bathymetry, which was illustrated by the profile consistency between the measurements and the model specifications on 10/11/2016 as shown in Figure 37. The profile comparisons on 11/15/2016, demonstrated how the calculated results reproduced the measured bed changes.

Figure 36. Nineteen transects perpendicular to the lake shoreline. The red rectangle indicates the nearshore ADCP bathymetry survey area, and the red dot is the location of the ADCP station, BHSHOO1.

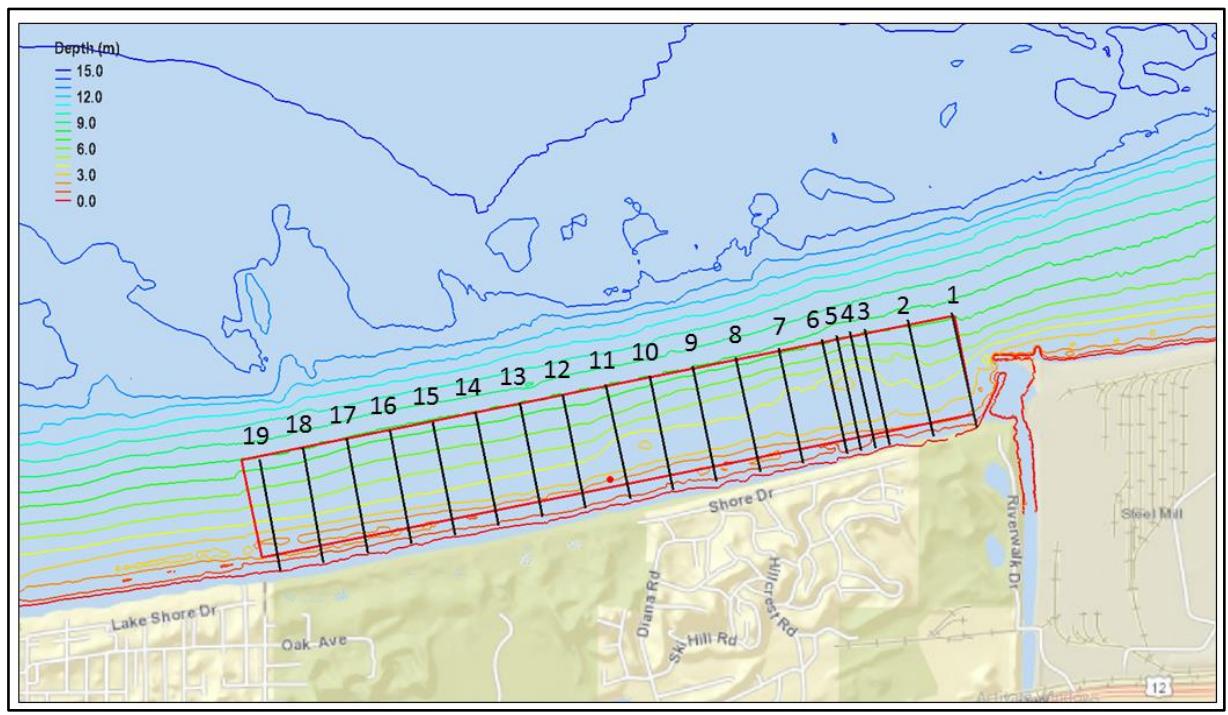


Figure 37. Measured and calculated profiles (transects 02-19) on 10/11/2016 and adjusted 11/15/2016 (red line - model; blue line - measured data).

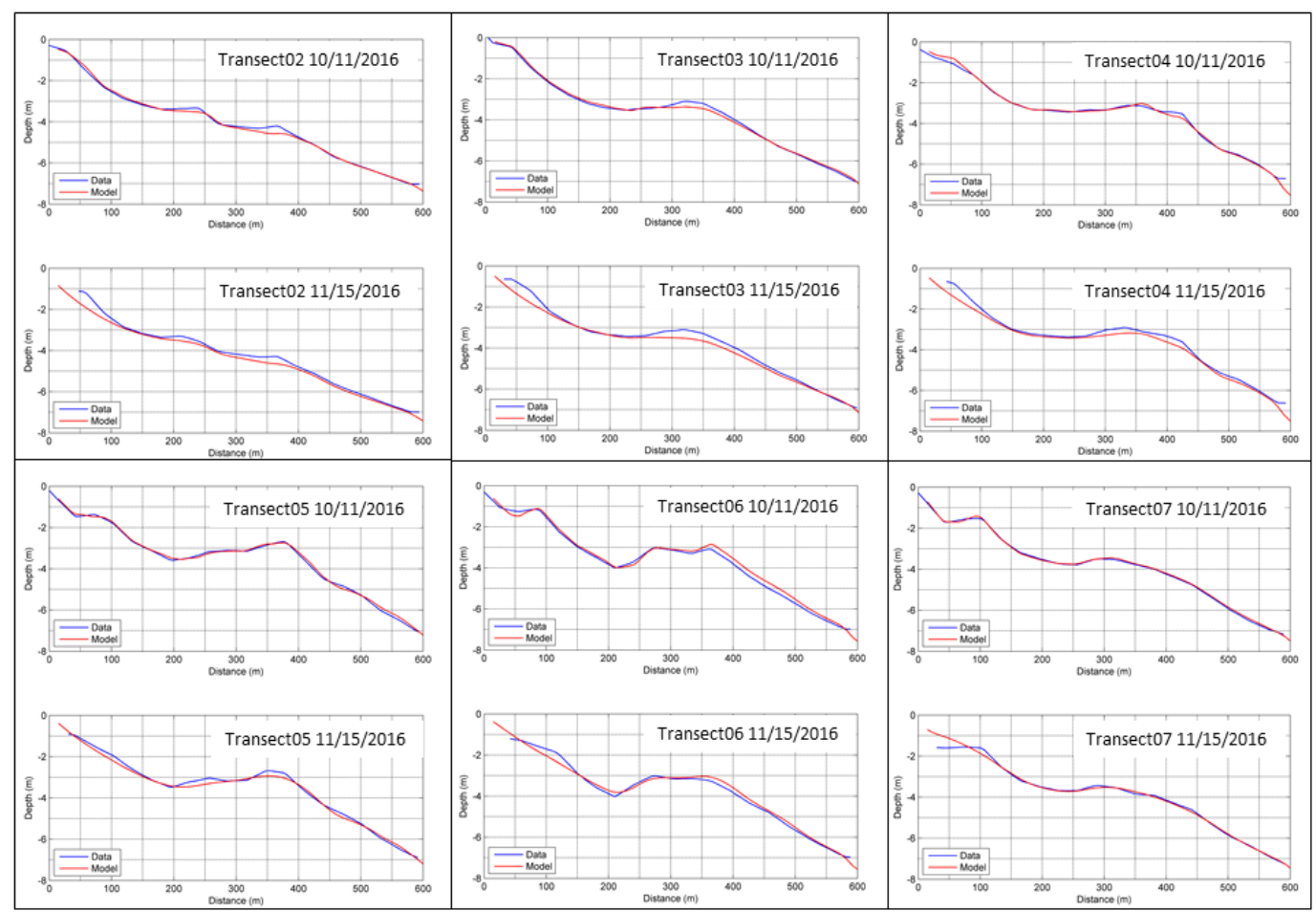

Figure 37. (continued).
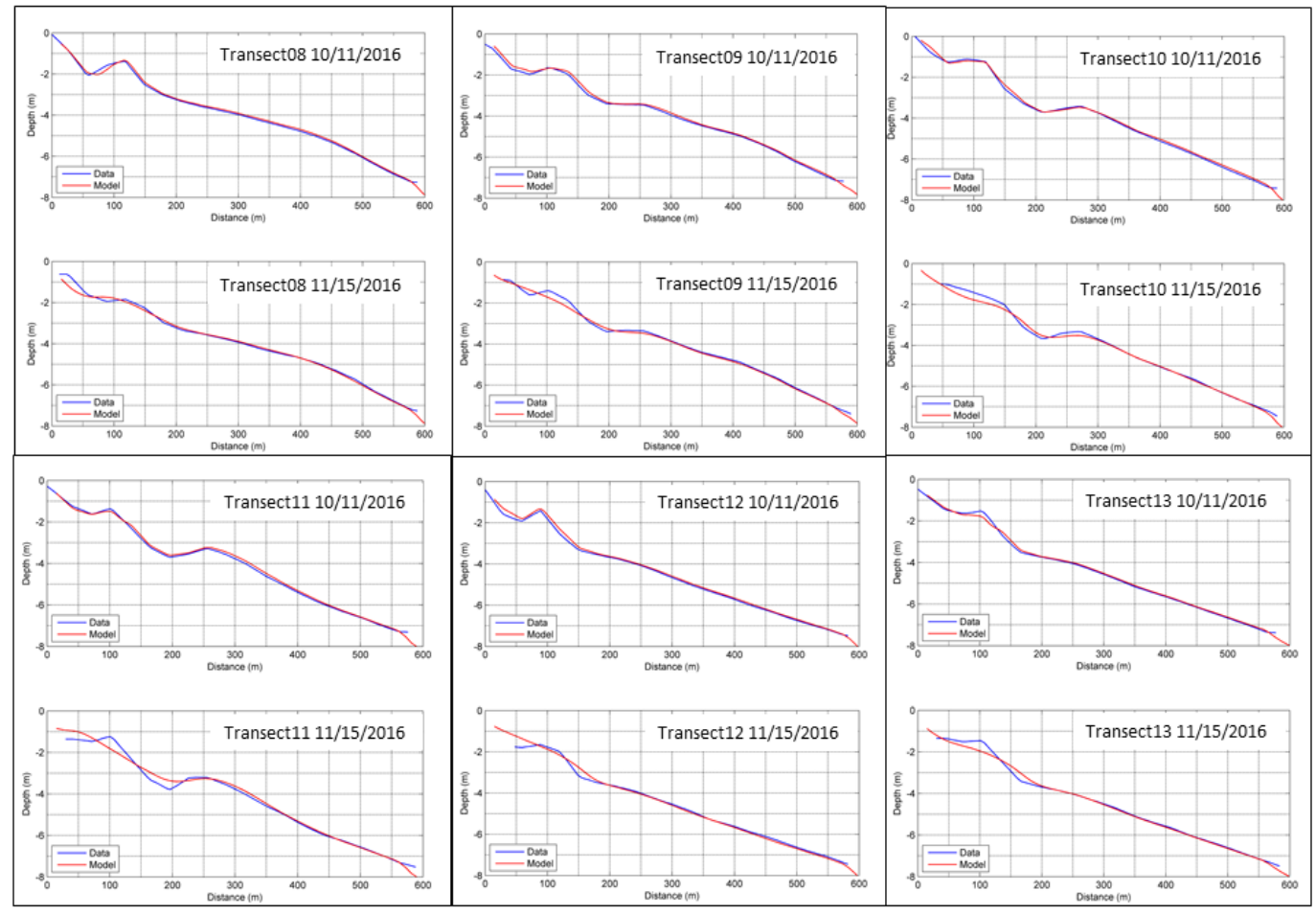
Figure 37. (continued).

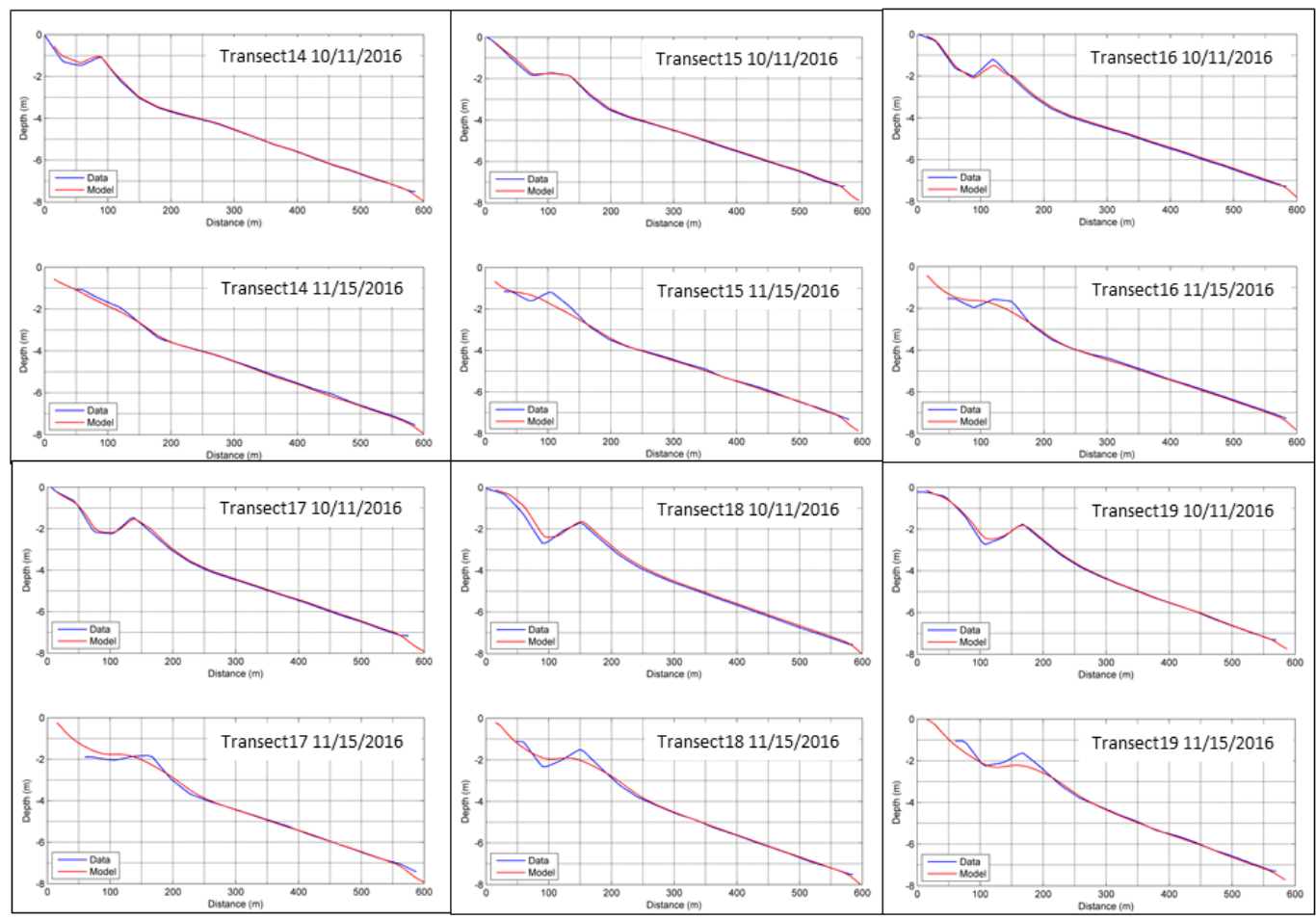

The observed bed changes from 10/11/2016 to 11/15/2016, were not meaningful in the nearshore area of transects 2,3 , and 4 , but the calculations predicted great sediment loss and bed changes in these transects (Figure 37). Sand bars were observed in the 10/11/2016, profiles in 15 other transects, located at different distances from the shoreline, varying from $80 \mathrm{~m}$ (transects 5 and 6) to $170 \mathrm{~m}$ (transect 19). Both the measurements and the model results indicated that the bars were observed in transects 5,6 , and 10 on 11/15/2016. The measurements showed that sand bars in transects $7,11,13,15,18$, and 19 were present consistently both on 10/11/2016 and 11/15/2016 but were most easily observed in transects 9 , 16 , and 17 on 10/11/2016 and became minuscule on 11/15/2016. In those transects, the model results showed that sand bars tended to be smoothed due to sediment movement. Although sand bars were present in some transects from 10/11/2016 to 11/15/2016 no discernible bar migration was observed in cross-shore direction over the period. Based on the bathymetry measurements and the model calculations, the above analysis on sand bar migration is summarized in Table 5 . 
Table 5. Sand bar locations in 19 measured transects on 10/11/2016 and $11 / 15 / 2016$.

\begin{tabular}{|c|c|c|c|c|}
\hline & \multicolumn{2}{|c|}{ Sand Bar (10/11/2016) } & \multicolumn{2}{|c|}{ Sand Bar (11/15/2016) } \\
\hline Profile & Presence & $\begin{array}{l}\text { Distance from Shoreline } \\
\qquad(\mathrm{m})\end{array}$ & Presence & $\begin{array}{l}\text { Distance from Shoreline } \\
\qquad(\mathrm{m})\end{array}$ \\
\hline 1 & No & N/A & No & $\mathrm{N} / \mathrm{A}$ \\
\hline 2 & No & N/A & No & $\mathrm{N} / \mathrm{A}$ \\
\hline 3 & No & $\mathrm{N} / \mathrm{A}$ & No & $\mathrm{N} / \mathrm{A}$ \\
\hline 4 & No & $\mathrm{N} / \mathrm{A}$ & No & $\mathrm{N} / \mathrm{A}$ \\
\hline 5 & Yes & 70 & No & $\mathrm{N} / \mathrm{A}$ \\
\hline 6 & Yes & 80 & No & $\mathrm{N} / \mathrm{A}$ \\
\hline 7 & Yes & 100 & Yes & 100 \\
\hline 8 & Yes & 120 & No & N/A \\
\hline 9 & Yes & 100 & Yes & 100 \\
\hline 10 & Yes & 100 & No & $\mathrm{N} / \mathrm{A}$ \\
\hline 11 & Yes & 100 & Yes & 100 \\
\hline 12 & Yes & 85 & Yes & 85 \\
\hline 13 & Yes & 100 & Yes & 100 \\
\hline 14 & Yes & 85 & No & $\mathrm{N} / \mathrm{A}$ \\
\hline 15 & Yes & 110 & Yes & 105 \\
\hline 16 & Yes & 120 & Yes & 120 \\
\hline 17 & Yes & 135 & Yes & 160 \\
\hline 18 & Yes & 150 & Yes & 150 \\
\hline 19 & Yes & 170 & Yes & 170 \\
\hline
\end{tabular}

The measured and calculated morphology changes were obtained by subtracting depth values in 11/15/2016 from those in 10/11/2016. The areas with positive values represent sediment accretion, and negative values represent sediment erosion in Figure 38. 
Figure 38. Comparisons of morphology changes between the ADCP surveys and the CMS calculations from $10 / 11 / 2016$ to $11 / 15 / 2016$. Warmer colors represent sediment accretion, and cooler colors sediment erosion. The ADCP survey difference measurements are (top panel) confined to the survey bounds (outlined region). The survey bounds are outlined in the CMS calculation differences (bottom panel), but the CMS calculations span the full model domain.

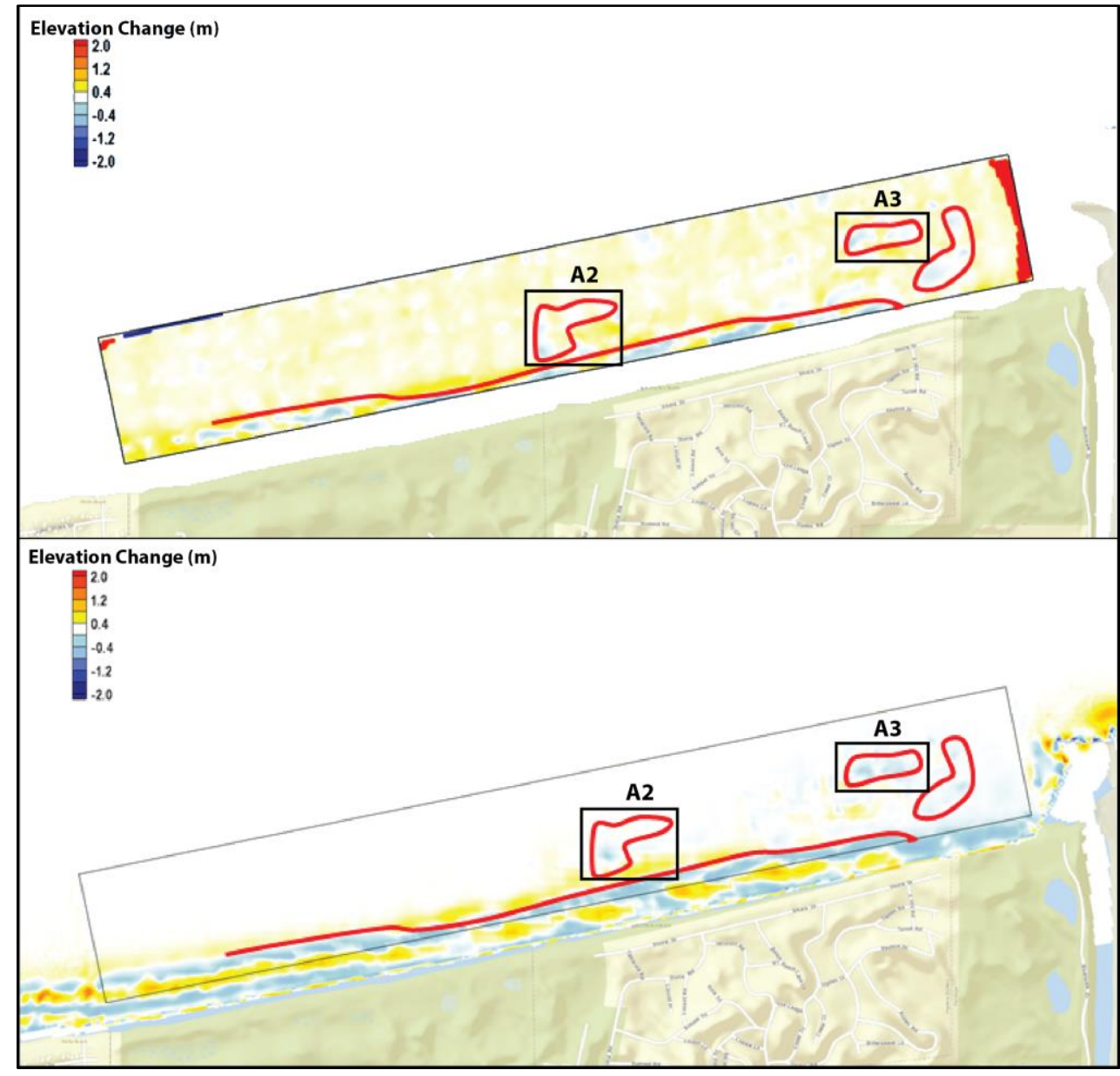

The survey data in Figure 38 (top panel) showed several erosion zones along the southern edge of the rectangular survey area (red lines). Related to the dredge placement operation, bed erosion also occurred near the central location of and in the eastern part of the survey area.

Major morphologic changes were represented by the model results in Figure 38 (bottom panel) although the magnitude and location of the bed change varied and the distribution pattern was not entirely spatially coherent. For example, the simulated bed erosion along the southern edge of the survey area and simulated sediment accumulation on the open lake and nearshore sides did not match the measured results. Near the dredge material placement sites, the calculated results indicated similar bed erosion 
(sediment dissipation) patterns to the measurements. Substantial model and data discrepancies are observed in the bed changes in the offshore area, where the data show consistent sediment accretion and the model shows little sediment movement. The combination of weak currents and lack of clear sediment sources within the survey area suggest that the large accretion phenomena observed in the measured data could possibly be attributed to bathymetry measurement or interpolation errors $( \pm 3 \mathrm{~cm}$ to $10 \mathrm{~cm}$ ), although no survey control points were available to confirm this.

Under the assumption that the large offshore accretion observed is due to measurement bias, the surveyed depth changes were adjusted by $7 \mathrm{~cm}$, and the volume changes from 10/11/2016 to 11/15/2016 were estimated based on this adjustment for the three areas shown in Figure 39. The measured and the calculated results were summarized in Table 6 . The boxed areas A2 and $\mathrm{A}_{3}$ (located in the vicinity of the peaks in the nearshore mounds in Figure 5) were areas of particularly noticeable erosion of sediment (bottom panel of Figure 38), indicating the preferential dissipation of placed sediment during the simulation period. The area A1 contains several large nearshore erosional areas (including A2 and A3) but does not display a corresponding large depositional area in the surf zone; therefore, area of A1 also corresponds to an area of net erosion. The net migration of sediment in the entire study area will be explored in depth in the next section.

Figure 39. Areas that correspond to the three locations of calculated volume change in Table 6 from 10/11/2016 to 11/15/2016, for three nearshore areas. A1 is the entire survey area, A2 is the small erosional area, and A3 the large erosional area around dredge material placement sites.

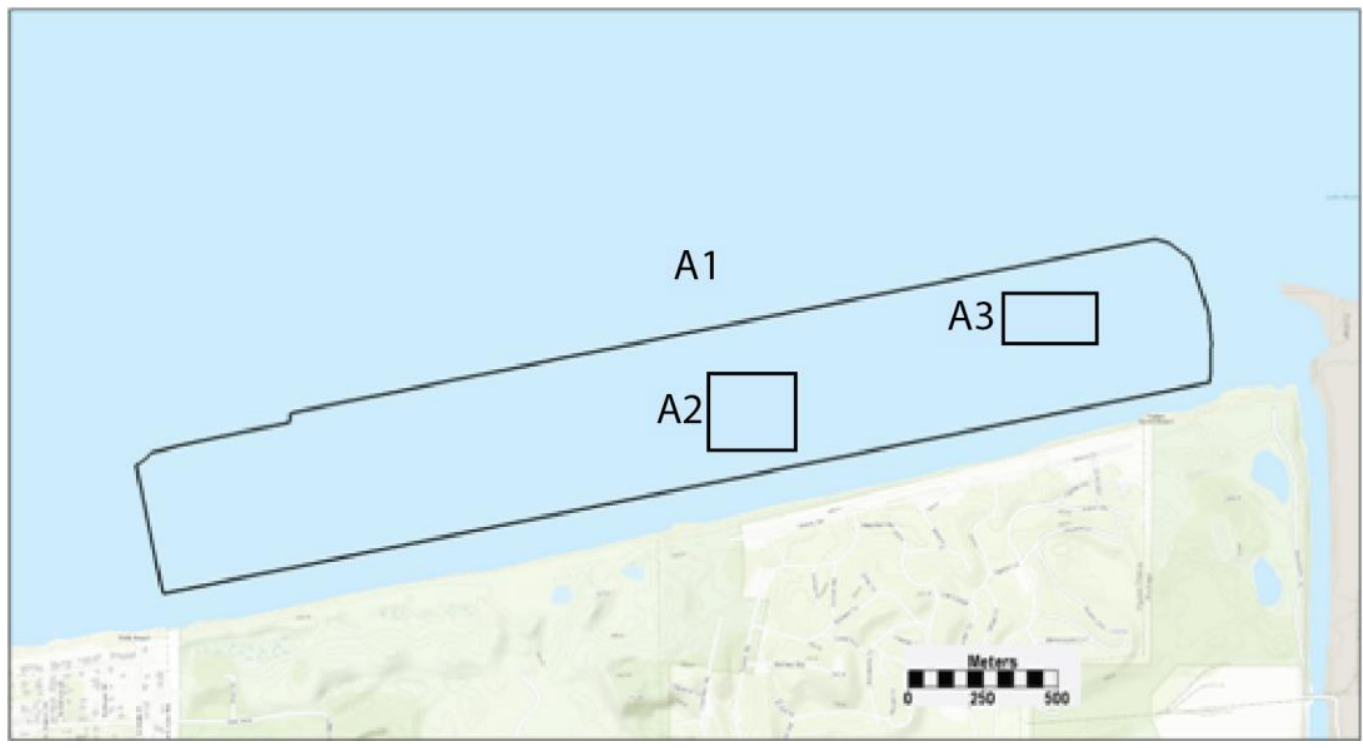


Table 6. Bed volume changes with the adjusted ADCP survey area from $10 / 11 / 2016$ to $11 / 15 / 2016$. Negative sign indicates bed erosion.

\begin{tabular}{|c|c|c|}
\hline \multirow{2}{*}{ Area } & \multicolumn{2}{|c|}{ Volume Change $\left(\mathrm{m}^{3}\right)$} \\
\cline { 2 - 3 } & Adjusted ADCP Survey & CMS \\
\hline 1 & $-13,032$ & $-20,436$ \\
\hline 2 & -367 & -847 \\
\hline 3 & $-1,738$ & $-2,827$ \\
\hline
\end{tabular}

\subsection{Modeling summary}

With the implementation of a field survey program, a coupled wave, hydrodynamic, sediment transport modeling system (CMS) was set up to calculate currents, waves, sediment transport, and morphology change around Ogden Dunes in southern Lake Michigan. Field data collection included ADCP and MBES bathymetric and beach topographic surveys from 6/2/2016 to 11/15/2016 and nearshore ADCP measurements of water level, current, and waves from 6/2/2016 to 10/11/2016. Driven by water level, offshore waves and wind, the CMS simulations include two 40-day calibration/validation periods, 7/20/2016 to 8/30/2016, and 10/10/2016 to $11 / 20 / 2016$, to evaluate hydrodynamics, waves, and sediment transport. From this numerical modeling application, the major findings are as follows:

1. Field data collection is an integral component for the implementation of the CMS and the evaluation of physical forces driving sediment transport in the study area. Bathymetry measurements provide a validation for numerical simulations of nearshore sediment movement and beach profile changes.

2. The CMS results demonstrate the model's capability to simulate waves, current, water surface elevation, sediment transport, and morphology changes in coastal lake environment. Wind and waves are the primary forcing mechanisms for the modeling system. Currents are weak in offshore area, and storm-/wave-driven currents are dominant in surf zone area.

3. The calculated morphology changes show that more sediment movement occurs in the nearshore area driven by strong alongshore currents. The validation to morphology demonstrates the model's capability to calculate spatial changes in bed volume and sand migration. 


\section{Morphologic Change}

The objective of this section was to analyze the survey data to determine changes in the nearshore morphology in the months following the July 2016 nearshore placement. The focus of the morphology change analysis was the change in the DEMs and the surveyed profile lines of the 06/02/2016; 10/11/ 2016; and 11/15/2016, ADCP surveys (Table 3). The 06/20/2016, ADCP survey, as well as the 07/25/2016, and 09/08/2016, MBES surveys, were processed into DEMs but not included in this analysis due to the presence of the independent dredging barge observed working in the study area for NIPSCO on 09/08/2016 (Figure 13), and the uncertainty surrounding its activities for the months of July, August, and September of 2016. To accomplish this morphology change analysis, the differences between the pre-placement survey (06/02/2016) and the two post-placement surveys retained (10/11/2016, and 11/15/2016) were computed, and how the 10/11/2016, survey compared to the $11 / 15 / 2016$, one was discussed.

\subsection{Survey data processing and Digital Elevation Model (DEM) generation}

Analysis of the bathymetric data was performed using the Geomorphic Change Detection (GCD) software (Wheaton et al. 2010) in ArcMap (Esri 2016). The GCD software facilitated the development of DEMs-ofdifference and the analysis of the errors. DEM error may include error due to the finite accuracy of the instrument or errors associated with point-toraster interpolation methods.

The ADCP surveys were processed by exporting the classic ASCII output from WinRiver II for post-processing in the Velocity Mapping Toolbox (VMT) (Parsons et al. 2013). A tide file of water surface elevations (in North American Vertical Datum of 1988 [NAVD88]) for each transect in each survey was derived from the nearest USGS gauge station (PortageBurns Waterway at Portage, Indiana; gauge number 04095090; USGS, 2019). The ASCII file for each survey and the corresponding tide file were imported to VMT and the "Export Multi-beam Bathymetry" tool was used to create a comma separated value (CSV) file containing geo-referenced bed elevations computed from the depths measured by each beam and corrected for the pitch and roll of the ADCP. Horizontal positions for the 
ADCP data were exported from VMT in UTM Zone $16 \mathrm{~N}$ coordinates and bed elevations were exported in NAVD88.

The beach survey data required minimal post-processing. CSV files containing the position (Indiana State Plane Coordinate System West 1983) and elevation (NAVD88) of each beach survey data point were processed in the NOAA Vertical Datum Transformation v3.6.1 tool (NOAA 2018) to transform the horizontal coordinates into geographic (latitude, longitude) coordinates, and these data were imported into ArcMap and projected into UTM Zone $16 \mathrm{~N}$ coordinates to maintain a common coordinate system with the exported ADCP survey data. The 08/09/2016, beach survey was merged with the $07 / 20 / 2016$, ADCP survey data as it was the closest available, and the 10/11-12/2016, beach survey was merged with $\mathrm{ADCP}$ survey data from the same 2 days. The point cloud data from the beach surveys and ADCP surveys were analyzed using the GCD software in ArcMap. Each survey was converted to a DEM with a grid size of $30 \mathrm{~m}$ using Natural Neighbor interpolation.

\subsection{Profile data and DEMs}

Figure 40 shows 19 of the 50 surveyed profile lines for the three ADCP surveys included in this analysis (06/02/2016, 10/11-12/2016, and 11/15/2016) - the same 19 described in Section 6.3.4. Note that the 10/11$12 / 2016$ survey will be referred to as 10/11/2016 in the following sections for brevity. The cross-shore spacing of the points in each profile line was $6 \mathrm{~m}$, and the alongshore spacing of the majority of the cross-shore profiles shown here was approximately $225 \mathrm{~m}$. Profile lines 3, 4, 5, and 6 shown here were spaced approximately $75 \mathrm{~m}$ apart to increase the resolution over the nearshore placement site. 
Figure 40. Locations of the selected profile lines for the 06/02/2016, 10/11/2016, and 11/15/2016 ADCP surveys plotted over the 10/11/2016 ADCP survey DEM.

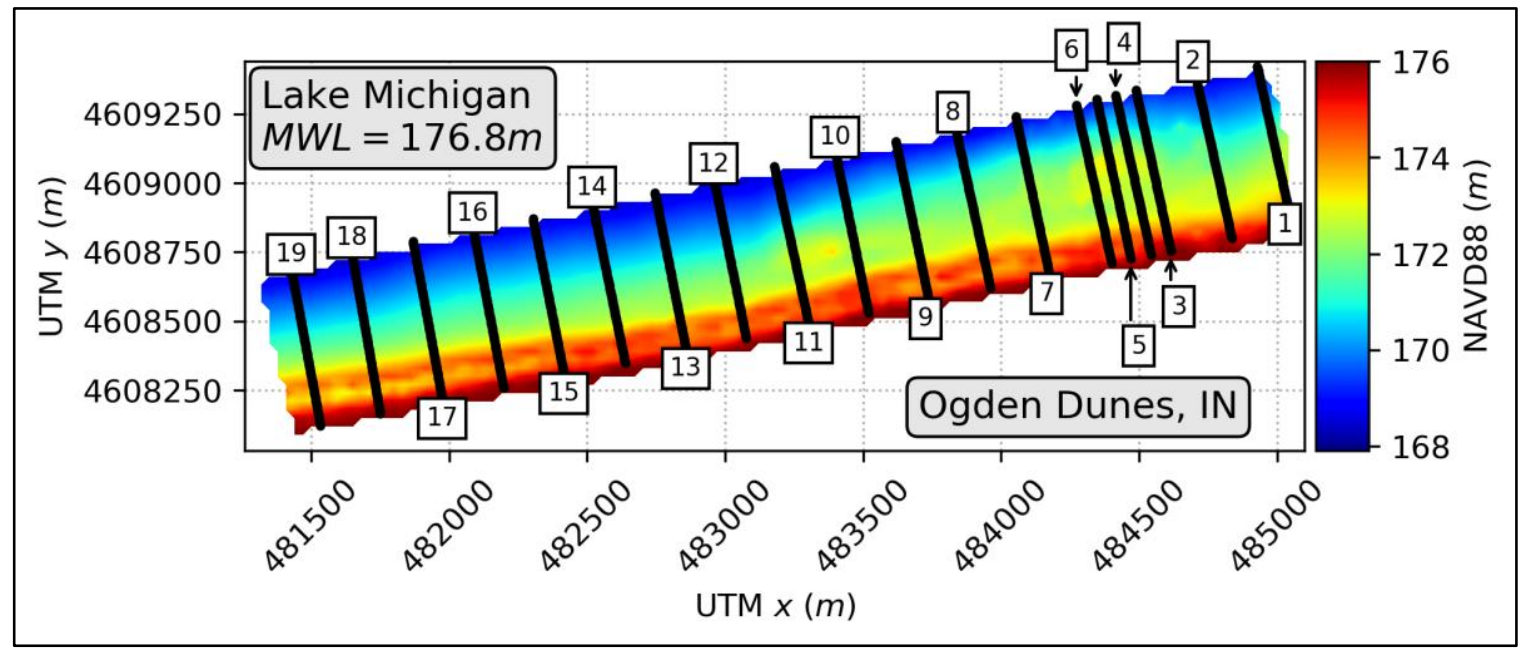

The generated DEM surfaces for the three ADCP surveys are shown in Figures 41, 42, and 43. The 06/02/2016 survey (Figure 41) was preplacement (Table 3) and represented the baseline surface with which to compare the 10/11/2016 and the 11/15/2016 survey DEMs. The 10/11/2016 survey (Figure 42) showed the sand deposited by the nearshore placement (the local high point located at approximately UTM $x$, UTM $y=484500,4609000 \mathrm{~m}$. The data shown in Figure 42 also included the merged beach topography from the 10/11-12/2016 RTK-dGPS beach survey. Figure 43 shows the 11/15/2016 survey DEM; on casual inspection, there was little difference in the position of the newly placed nearshore material between the 11/15/2016 DEM and the DEM from the preceding month (10/11/2016 - Figure 42).

Figure 41. DEM generated from the 06/02/2016 ADCP survey data.

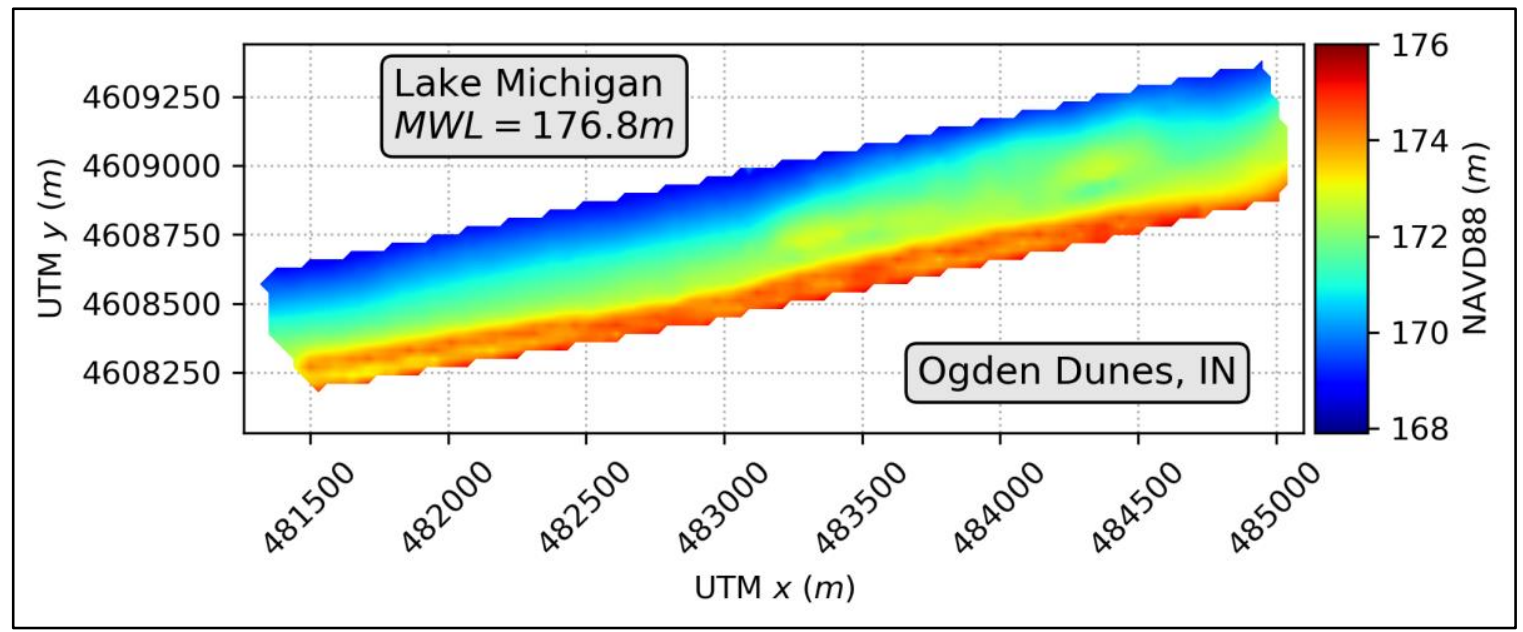


Figure 42. DEM generated from the 10/11/2016 ADCP survey data merged with the 10/11/2016 RTK-dGPS beach survey data.

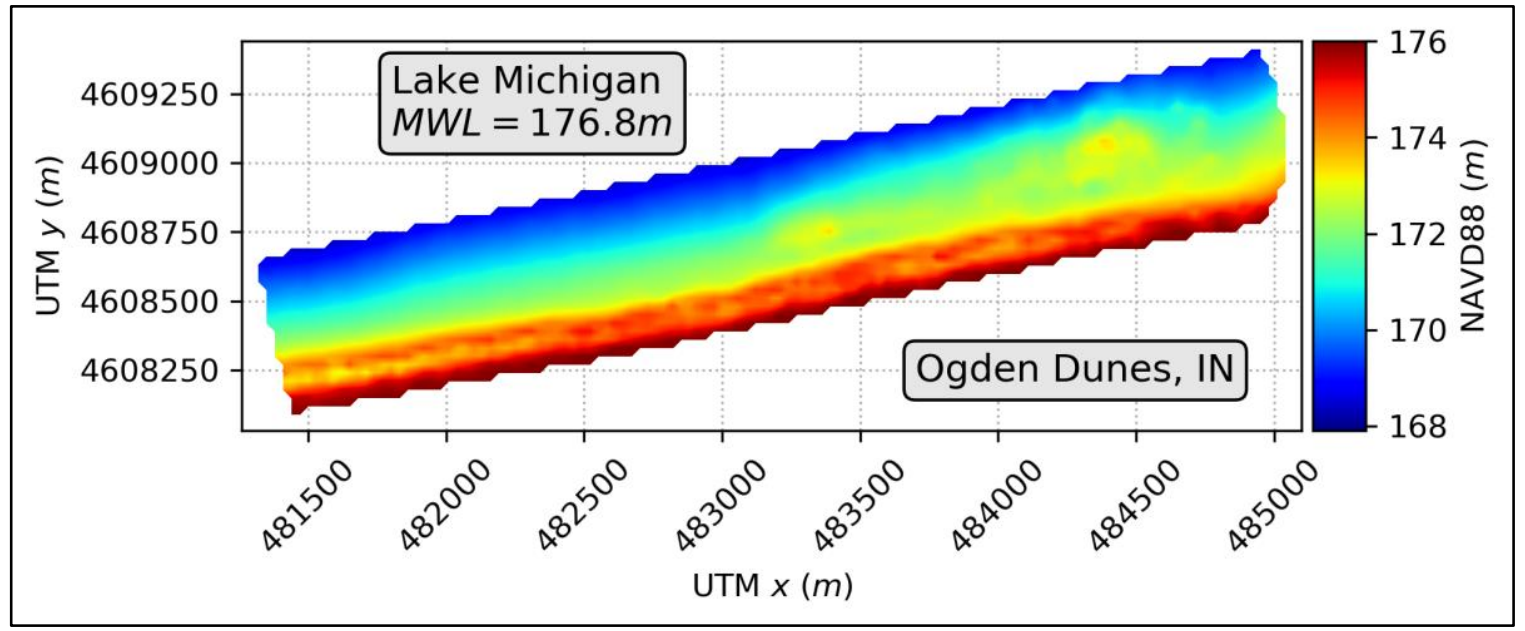

Figure 43. DEM generated from the 11/15/2016 ADCP survey data.

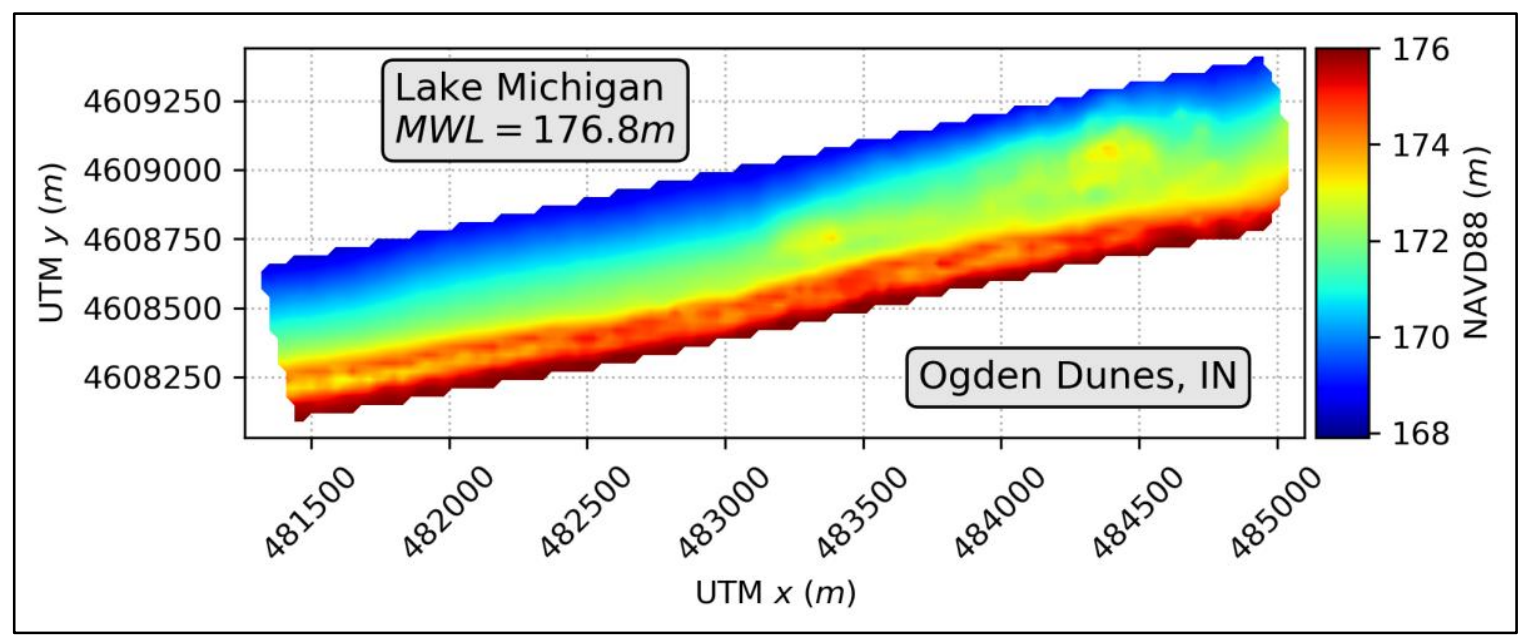

To better consider the onshore/offshore migration of the nearshore material, it was convenient to transform the coordinate system into a cross-shore/alongshore frame of reference. This was done by defining a straight line along the shoreline (the alongshore axis) and generating a line perpendicular to the alongshore axis to define the cross-shore axis. The new coordinate system relative to the original UTM $x$ and UTM $y$ coordinate system is shown in Figure 44. Once this coordinate system was defined, the alongshore position of all profile lines was adjusted such that profile 1 is at alongshore position $x=0$, and the alongshore position increased with the increase in profile line number (moving west). 
Figure 44. Rotation of the new alongshore/cross-shore coordinate system relative to the UTM $x, y$ coordinate system of the original data. The DEM is from the 10/11/2016 ADCP survey including beach topography.

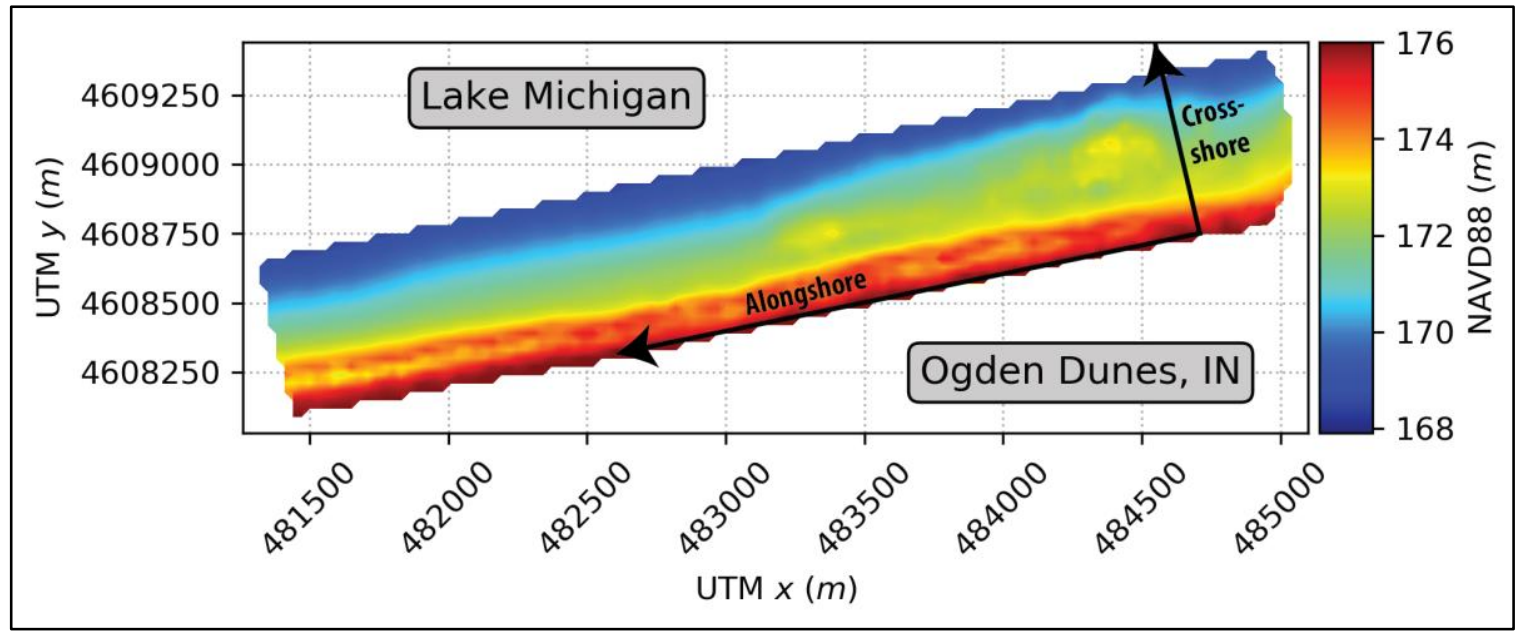

With the new coordinate system defined, the profile data were plotted in a more intuitive coordinate system to consider placed sediment migration. A comparison among the 06/02/2016, 10/11/2016, and 11/15/2016 ADCP survey results for each of the 19 profile lines is shown in Figures $45-51$ (three profiles per figure). The minimum cross-shore position ( $\mathrm{x}_{\mathrm{cmin}}$ ) that was quantified in all three of the survey profiles is shown as a dotted line, and the dashed line indicates the demarcation point between the more offshore placement region and the sandbar region $(x=180 \mathrm{~m})$ determined by visual inspection of the profile data. The mean water surface elevation at the nearby Calumet Harbor, Illinois, tide gauge (9087044; NOAA, 2013) from $06 / 02 / 2016$ to $11 / 15 / 2016$ was $176.75 \mathrm{~m}$. 
Figure 45. Comparison of the 06/02/2016 (red), 10/11/2016 (blue), and 11/15/2016 (black) survey results for Profiles 1 (a), 2 (b), and 3 (c). Dashed black line indicates the line demarcating the placement region and the sandbar region.

$X_{c m i n}$ (black dotted line) is the minimum cross-shore position common to all three surveys.

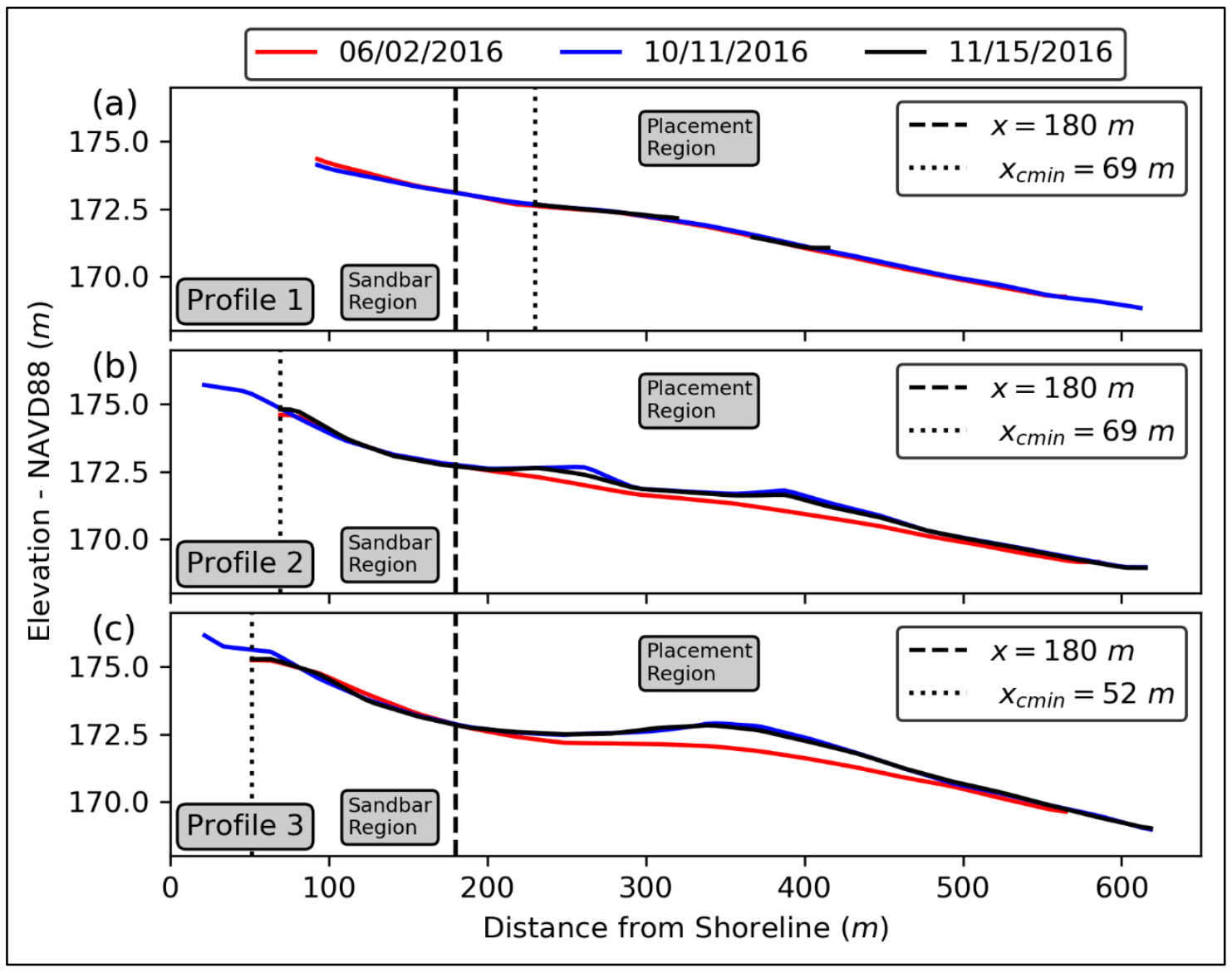


Figure 46. Comparison of the 06/02/2016 (red), 10/11/2016 (blue), and 11/15/2016 (black) survey results for Profiles 4 (a), 5 (b), and 6 (c). Dashed black line indicates the line demarcating the placement region and the sandbar region.

$\mathrm{X}_{\mathrm{cmin}}$ (black dotted line) is the minimum cross-shore position common to all three surveys.

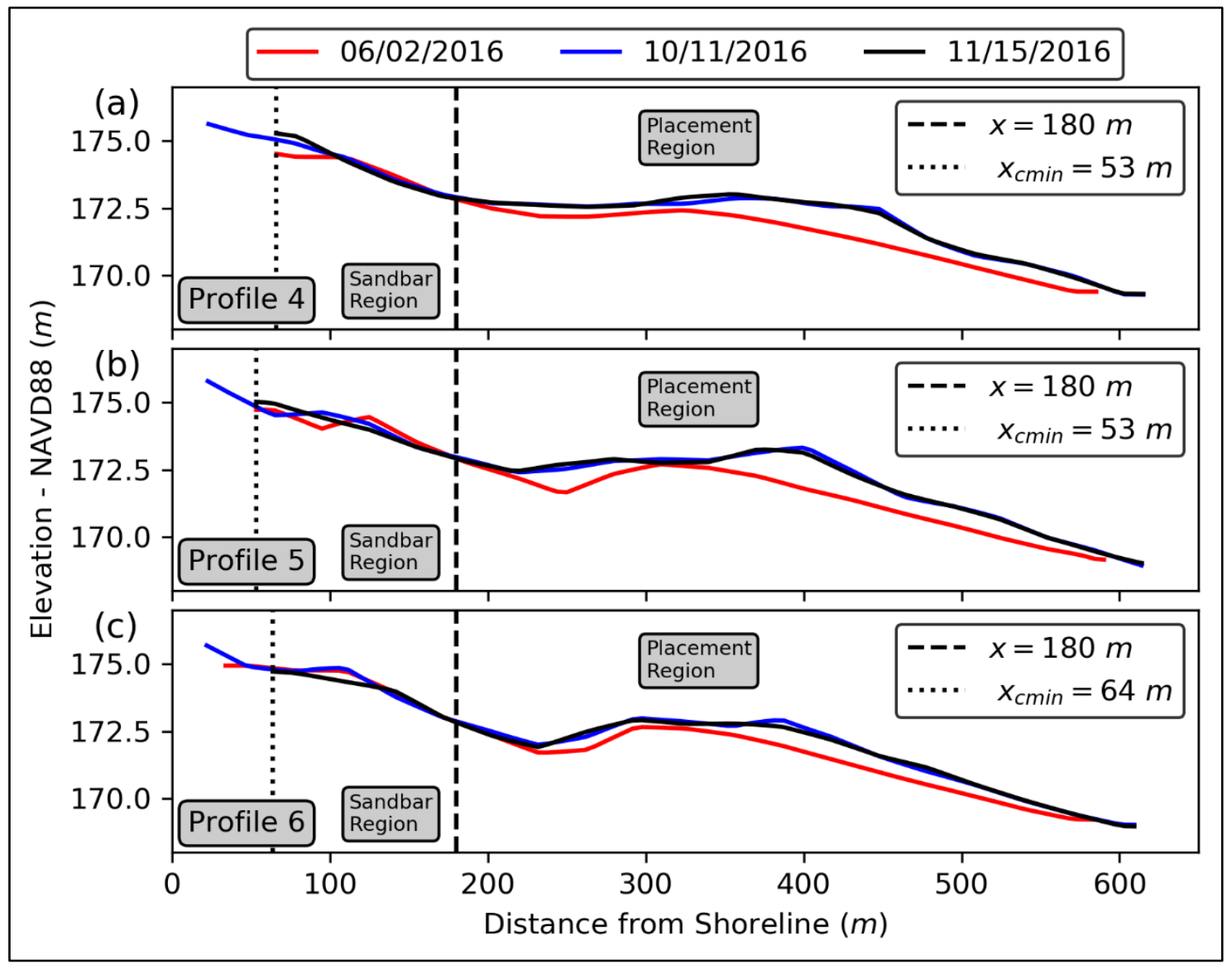


Figure 47. Comparison of the 06/02/2016 (red), 10/11/2016 (blue), and 11/15/2016 (black) survey results for Profiles 7 (a), 8 (b), and 9 (c). Dashed black line indicates the line demarcating the placement region and the sandbar region.

$\mathrm{X}_{\mathrm{cmin}}$ (black dotted line) is the minimum cross-shore position common to all three surveys.

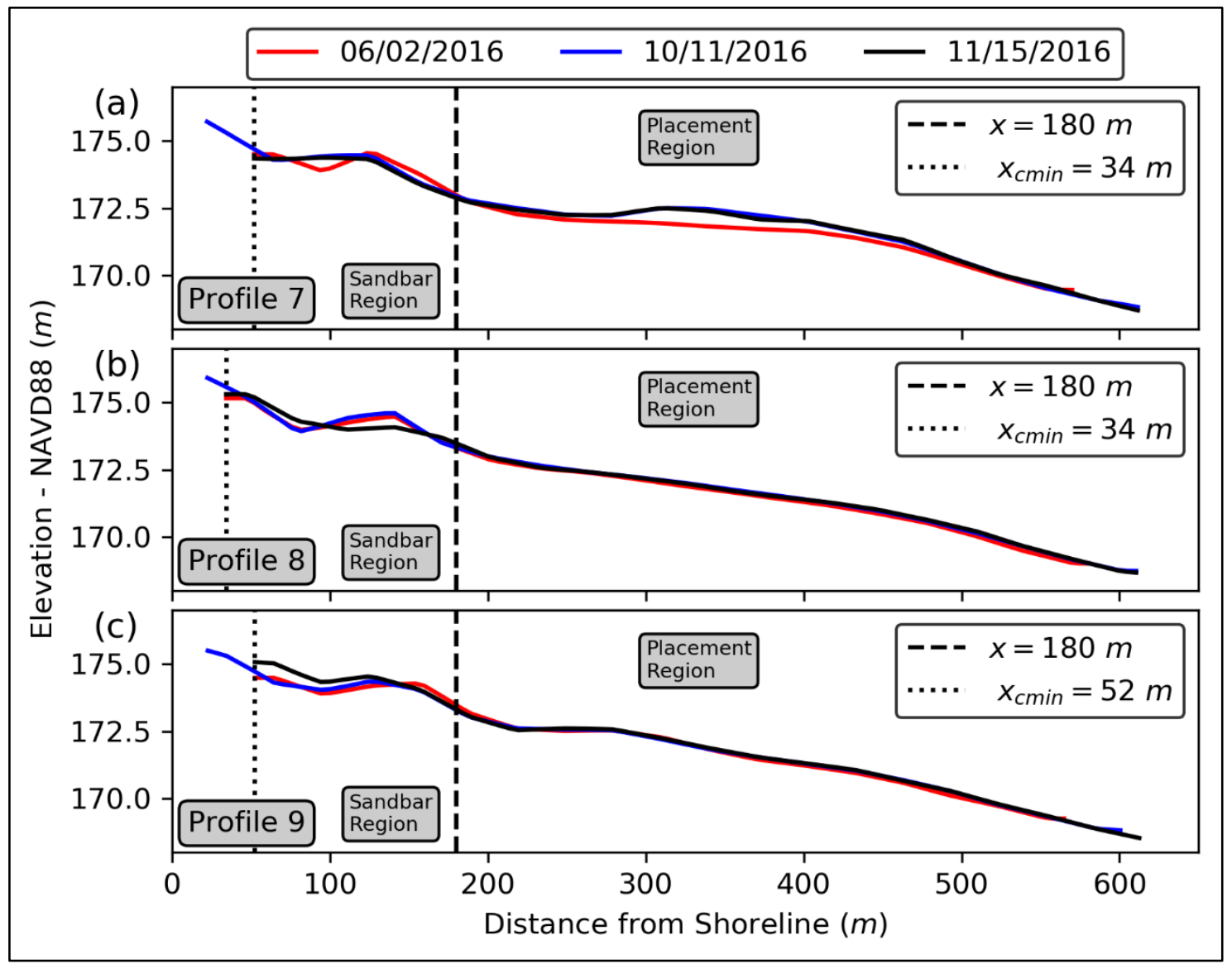


Figure 48. Comparison of the 06/02/2016 (red), 10/11/2016 (blue), and 11/15/2016 (black) survey results for Profiles 10 (a), 11 (b), and 12 (c). Dashed black line indicates the line demarcating the placement region and the sandbar region. $x_{c m i n}$ (black dotted line) is the minimum cross-shore position common to all three surveys.

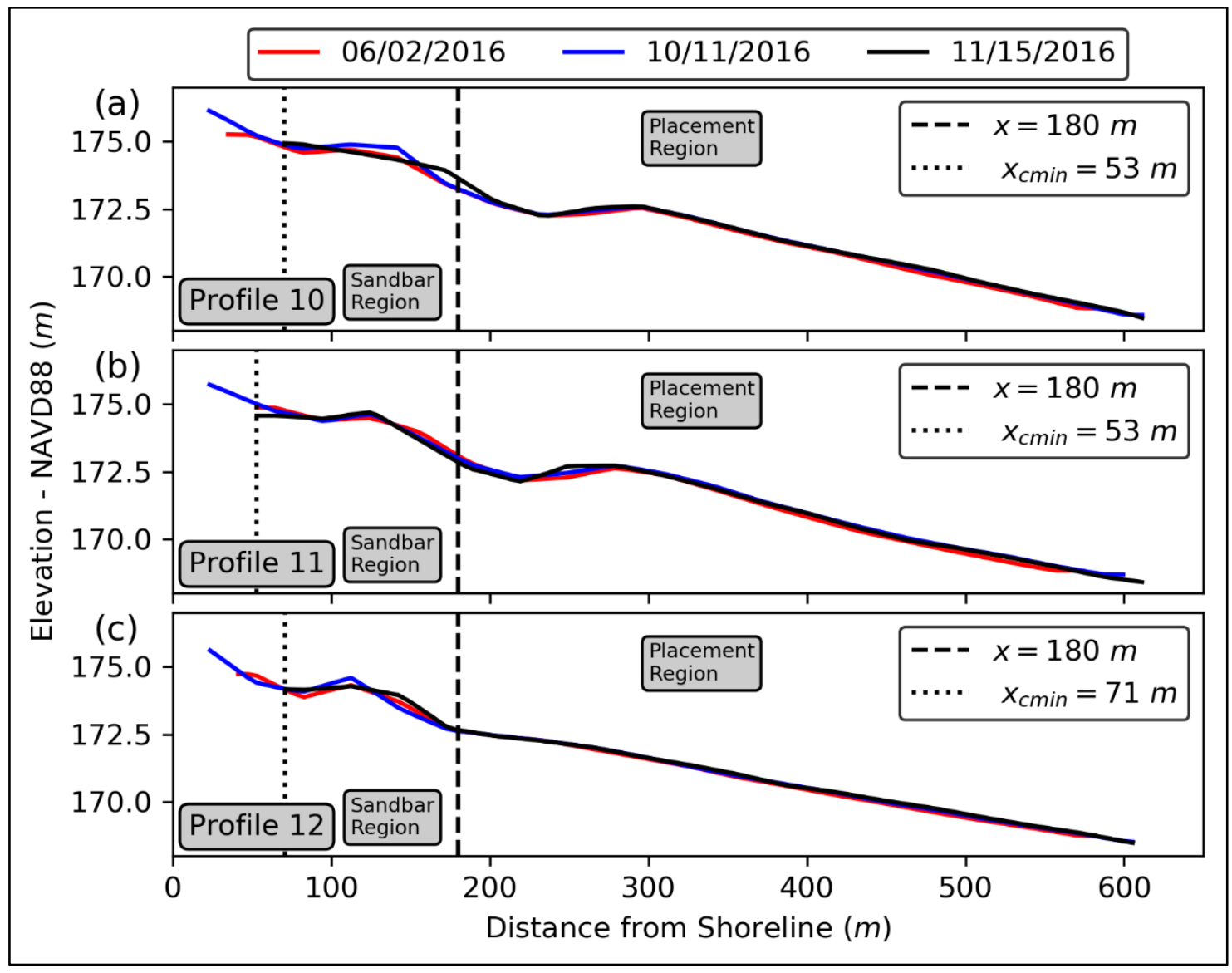


Figure 49. Comparison of the 06/02/2016 (red), 10/11/2016 (blue), and 11/15/2016 (black) survey results for Profiles 13 (a), 14 (b), and 15 (c). Dashed black line indicates the line demarcating the placement region and the sandbar region. $x_{c m i n}$ (black dotted line) is the minimum cross-shore position common to all three surveys.

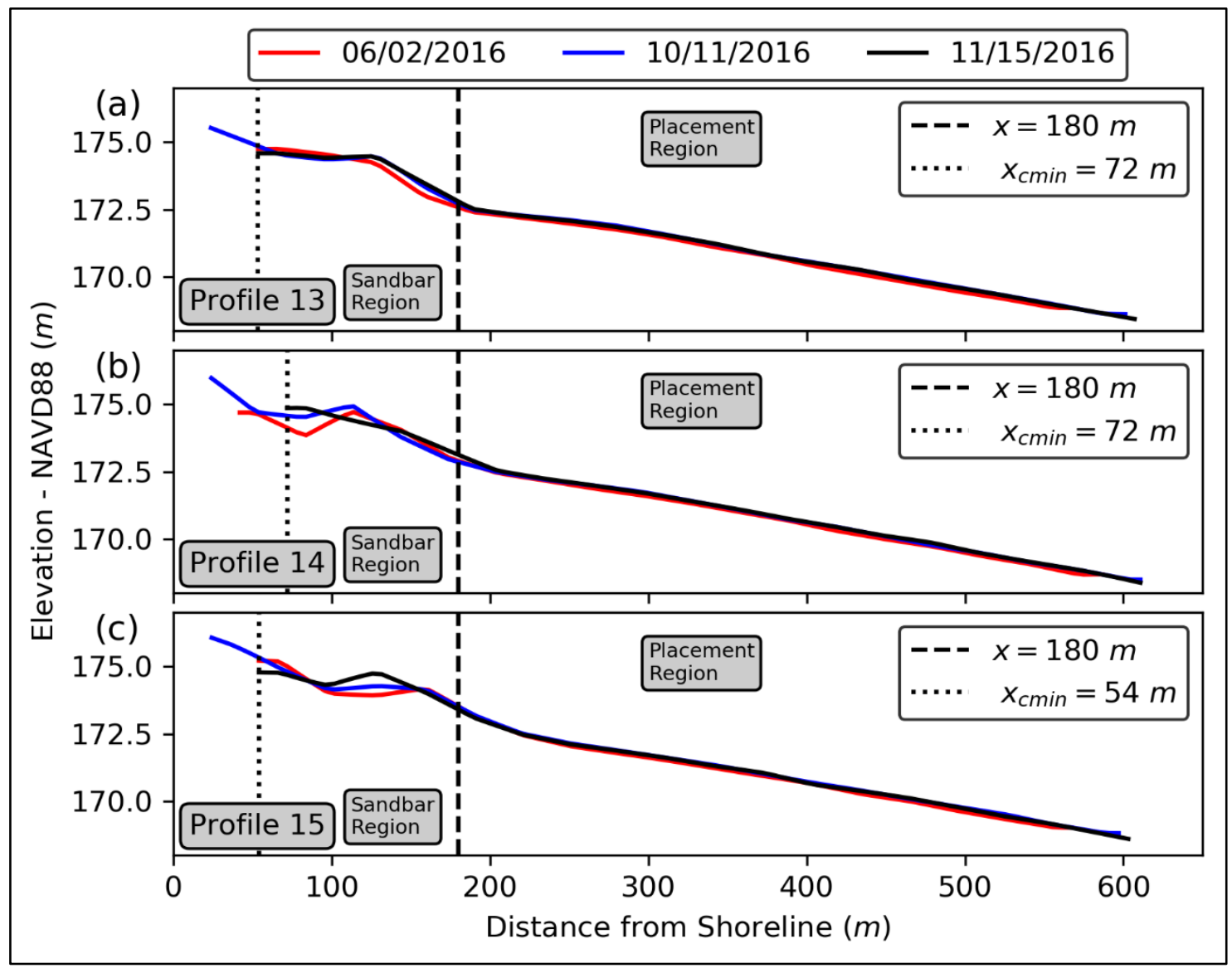


Figure 50. Comparison of the 06/02/2016 (red), 10/11/2016 (blue), and 11/15/2016 (black) survey results for Profiles 16 (a), 17 (b), and 18 (c). Dashed black line indicates the line demarcating the placement region and the sandbar region. $x_{c m i n}$ (black dotted line) is the minimum cross-shore position common to all three surveys.

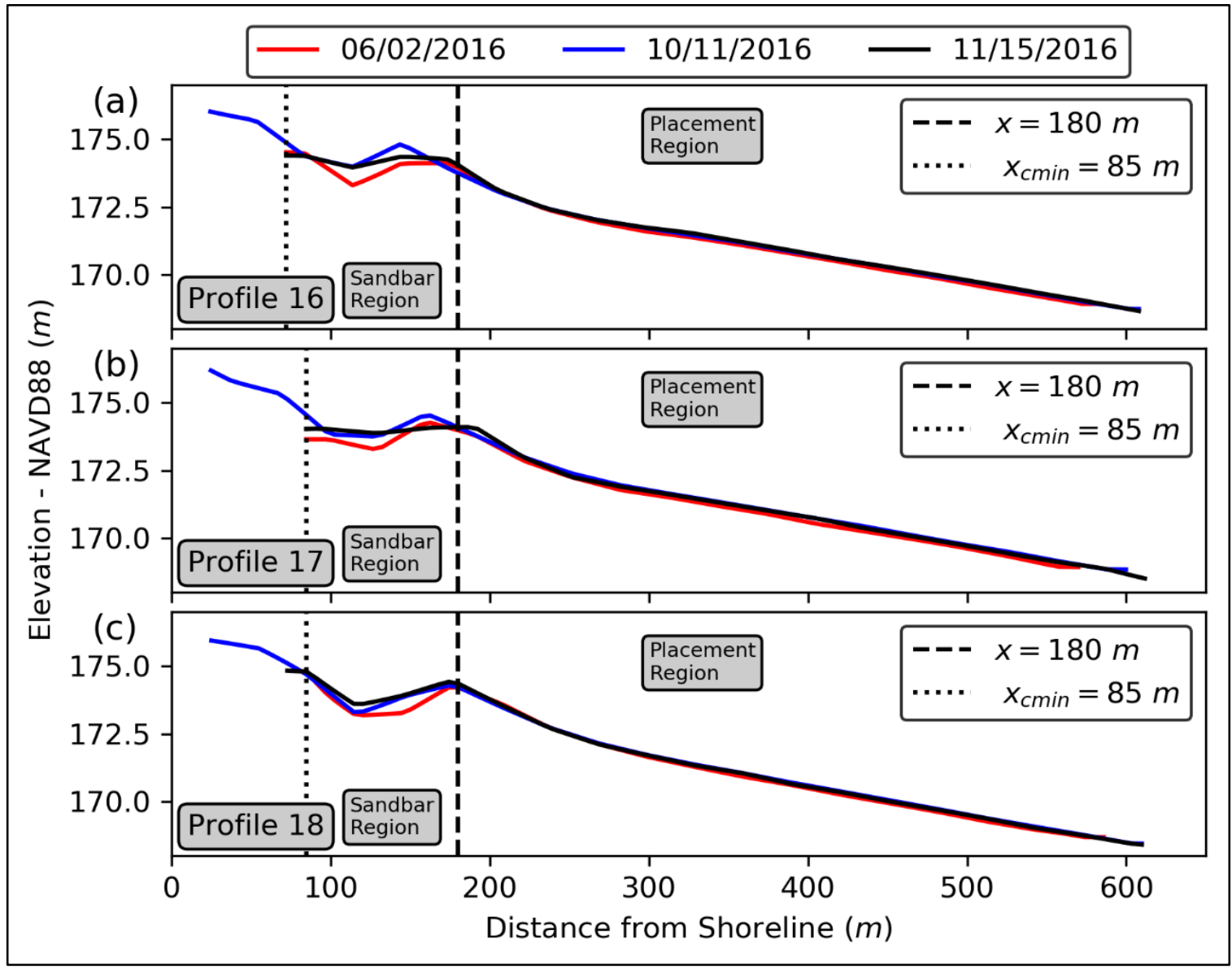

Figure 51. Comparison of the 06/02/2016 (red), 10/11/2016 (blue), and 11/15/2016 (black) survey results for Profile 19 (a). Dashed black line indicates the line demarcating the placement region and the sandbar region. $x_{c m i n}$ (black dotted line) is the minimum cross-shore position common to all three surveys.

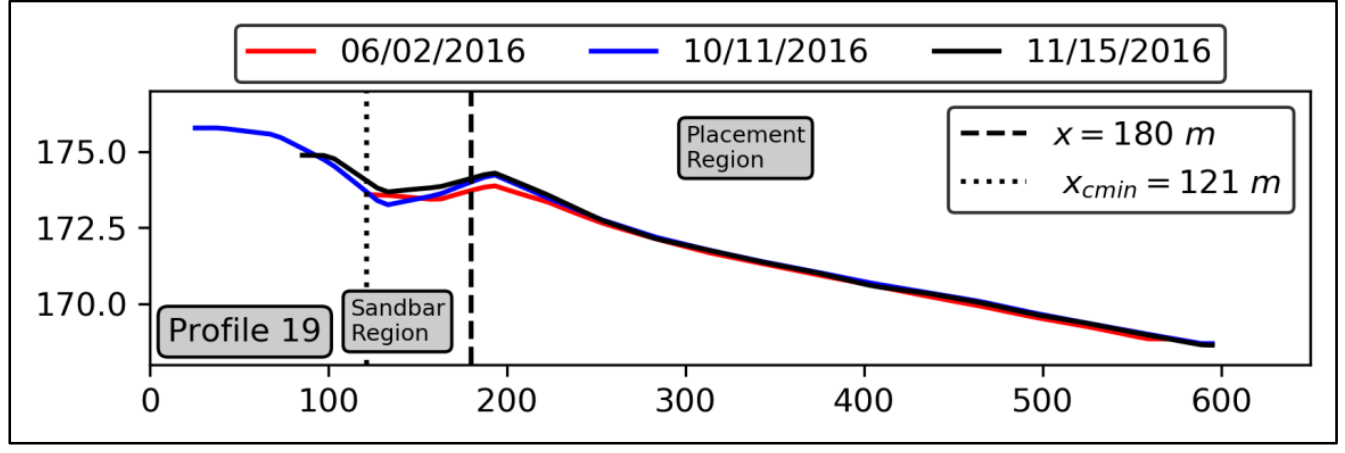


The pre-existing sandbar nearest to the shoreline (sandbar) was observed in the majority of the profile lines in all three surveys. The sandbar was small in Profiles 5 and 6 (Figure $46 \mathrm{~b}$ and c) for the 06/02/2016 and 10/11/2016 surveys (red and blue lines) and not easily defined for the 11/15/2016 survey (black line). Profiles $7-19$ (Figure 47-51) showed the sandbar far more prominently for all three surveys, although the precise position and size was variable among the three surveys. The sandbar was located progressively farther offshore between Profiles 16 (sandbar crest at $x \approx 175 \mathrm{~m}$ - Figure 50a) and 19 (sandbar crest at $x \approx 190 \mathrm{~m}-$ Figure 51a); thus, the demarcation of the offshore placement and sandbar regions at $x \approx 180 \mathrm{~m}$ began to break down at the far western edge of the study site. The nearshore placement material was visible in Profiles $2-7$ (Figures 45 - 47) in both of the post-placement surveys (10/11/2016 and 11/15/2016) - as observed in the large differences between the pre-placement (red) and two post-placement (blue and black) for those profile lines. The differences in the position of the nearshore placement material between 10/11/2016 and 11/15/2016 were more noticeable in these profile figures than the DEM surfaces in Figures 42 and 43.

\subsection{Variation in the post-placement surveys}

To illustrate the sediment motion between surveys, Figures 52 and 53 show the elevation difference between the 10/11/2016 and 06/02/2016 DEMs (Figure 52) and the 11/15/2016 and 10/11/2016 DEMs (Figure 53). Note that neither differenced surface contained the beach survey data, as no beach survey data were available for the pre-placement survey (06/02/2016). Warmer colors represent accretion, and cooler colors erosion. Figure 52 shows the location of the nearshore placement centered at approximately UTM $x$, UTM $y=484500,4609000 \mathrm{~m}$ (black box). Figure 53 indicated some rearrangement of the placed nearshore sediment between the 11/15/2016 and 10/11/2016 surveys, but it was difficult to categorize the motion as predominantly offshore or onshore. Both Figures 52 and 53 showed substantial sediment migration associated with the motion of the sandbar close to the beach between the three surveys although again the dominant direction of this migration was difficult to determine from the figures. 
Figure 52. Elevation difference between the 10/11/2016 ADCP survey DEM and the 06/02/2016 ADCP survey DEM ( $\Delta z=10 / 11 / 2016$ z - 06/02/2016 z).

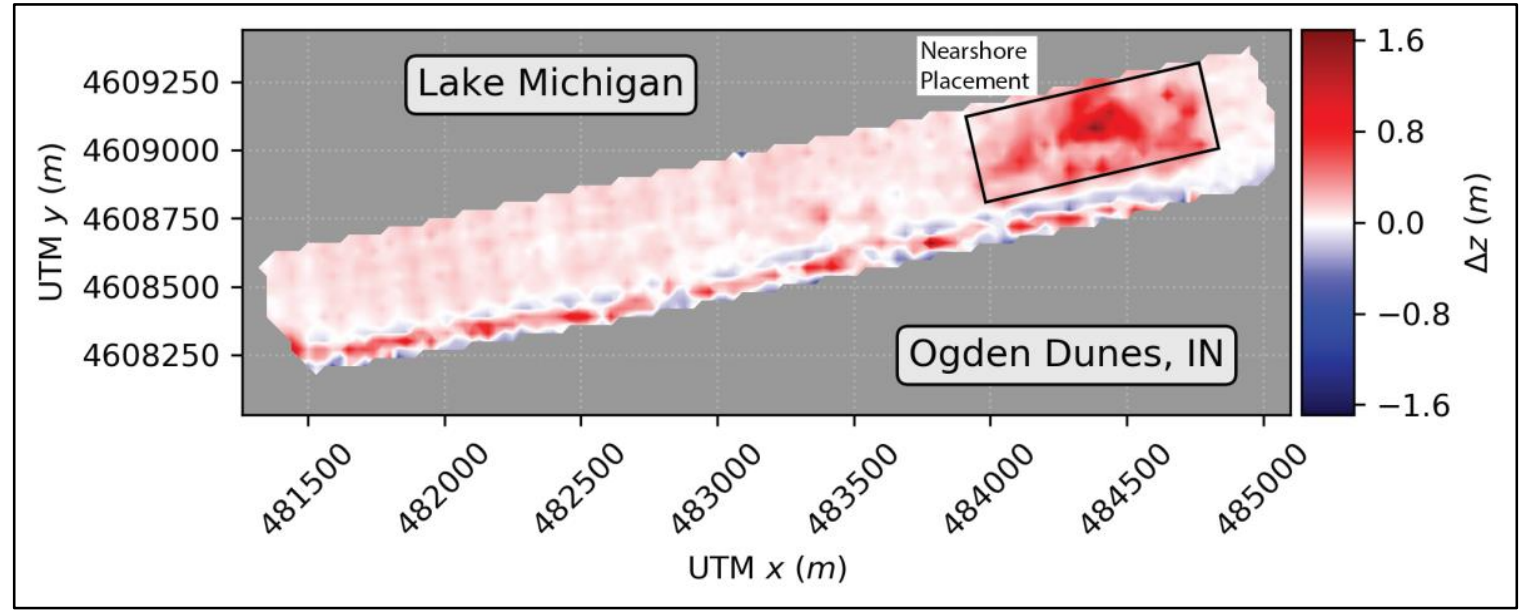

Figure 53. Elevation difference between the 11/15/2016 ADCP survey DEM and the $10 / 11 / 2016$ ADCP survey DEM $(\Delta z=11 / 15 / 2016 z-10 / 11 / 2016 z)$.

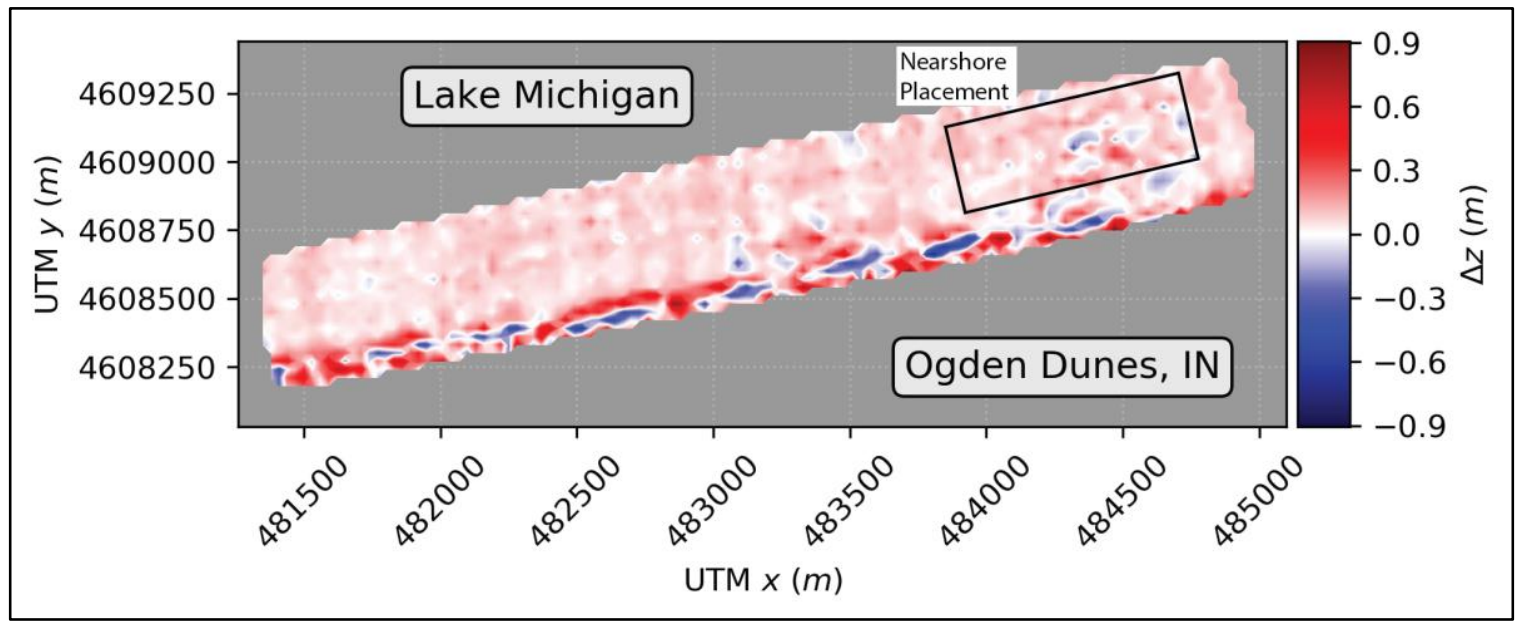

To quantify the change in the bathymetry of the study area postplacement, the differences between the post- and pre-placement surveys for both post-placement surveys (i.e., 10/11/2016 - 06/02/2016 relative to 11/15/2016 - 06/02/2016) were considered. This study was concerned about the total volume of the differenced surface to determine the net sediment gain or loss in the system between the two surveys.

The differenced volumes were calculated by summing the elevation differences between the two DEM surfaces multiplied by the cell area $(30 \mathrm{~m} \times 30 \mathrm{~m})$. The volume calculations were performed for the entire differenced surface and was also separated out into the more offshore nearshore placement region $\left(\mathrm{V}_{\mathrm{x}>18 \mathrm{om}}\right)$ and more onshore sandbar region $\left(\mathrm{V}_{\mathrm{x}<18 \mathrm{om}}\right)$ to determine which regions were gaining or losing sediment. 
Further, the centroid $\left(\mathrm{x}_{\mathrm{c}}, \mathrm{y}_{\mathrm{c}}\right)$ of the differenced volume was calculated to determine the dominant direction of the alongshore and cross-shore sediment motion between the two post-placement surveys (i.e., (Xc10/11-06/02 relative to $\mathrm{x}_{\mathrm{c} 11 / 15-06 / 02}$ and $\mathrm{y}_{\mathrm{c} 10 / 11-06 / 02}$ relative to $\mathrm{y}_{\mathrm{c} 11 / 15-06 / 02}$ ). Table 7 shows these values calculated for each differenced surface (10/11/2016 06/02/2016 and 11/15/2016 - 06/02/2016), as well as the change between the two post-placement surveys. The errors were estimated via Monte Carlo simulation (10,000 simulations) with the error in each cell determined by normal random number generation (zero mean and two times the standard deviation assumed to be $20 \mathrm{~cm}$ ).

Table 7. Volume $(V)$ and the centroid location $\left(x_{c}, y_{c}\right)$ of each differenced surface (10/11/2016 - 06/02/2016 and unadjusted 11/15/2016 - 06/02/2016), as well as the change between the two post-placement surveys.

\begin{tabular}{|c|c|c|c|}
\hline Parameter & $\begin{array}{c}10 / 11 / 2016- \\
06 / 02 / 2016\end{array}$ & $\begin{array}{c}11 / 15 / 2016- \\
06 / 02 / 2016\end{array}$ & $\begin{array}{c}\text { Change } \\
11 / 15-10 / 11\end{array}$ \\
\hline $\mathrm{V}\left(\mathrm{m}^{3}\right)$ & $240,647( \pm 11,970)$ & $375,455( \pm 11,611)$ & 134,808 \\
\hline $\mathrm{x}_{\mathrm{c}}(\mathrm{m})$ & $360( \pm 8)$ & $331( \pm 5)$ & -29 \\
\hline $\mathrm{y}_{\mathrm{c}}(\mathrm{m})$ & $1505( \pm 55)$ & $1603( \pm 33)$ & 98 \\
\hline
\end{tabular}

The results displayed in Table 7 were intriguing for several reasons. Note that the change in the centroid of the sediment volume between the $11 / 15 / 2016$ and the 10/11/2016 surveys indicated that the bulk of the sediment in the study area was located more onshore and farther to the west ( $\mathrm{x}_{\mathrm{c}}$ difference of $-29 \mathrm{~m}$ and $\mathrm{y}_{\mathrm{c}}$ difference of $98 \mathrm{~m}$ ) on 11/15/2016 than on 10/11/2016. The westward motion of the placed sand agreed well with prior determinations that the predominant littoral transport in this region was east-to-west (Arnold et al. 2018). Furthermore, a large increase in the volume of sediment $\left(+240,647 \mathrm{~m}^{3}\right)$ over the pre-placement survey (06/02/2016) was observed in the first post-placement survey (10/11/2016), presumably largely due to the nearshore placement. Note that this volume far exceeded the volume of the placed dredged material $\left(107,000 \mathrm{~m}^{3}-\right.$ see Section 4.2). This was likely partially due to the actions of the NIPSCO dredge viewed in the study area in September 2016 (see Section 5). If the September 2016 NISPCO dredge placement was identical to that described in Table 2 (or of comparable scope), then an additional $50,000 \mathrm{~m}^{3}$ of dredged material was placed in the study area (the precise volume placed was unavailable). An additional possibility was that the presence of small survey measurement bias influenced the measured volumes, as described in detail below. 
Surprisingly, the second post-placement survey (11/15/2016) indicated an even larger volume of sediment gained in the study area, 375,455 $\mathrm{m}^{3}-$ an increase of $134,808 \mathrm{~m}^{3}$ in a little over a month $(10 / 11 / 2016$ to $11 / 15 / 2016)$ with no dredges depositing sediment in the study site. It seemed unlikely that an additional $134,808 \mathrm{~m}^{3}$ of sediment moved into the study site in between the two post-placement surveys; thus, this likely represented an error induced by measurement bias discrepancy between the 11/15/2016 and the 10/11/2016 surveys (also see Section 6.3.4). This small measurement bias was difficult to observe in the differenced DEM (Figure 53), but was striking when considering the cumulative effect it has on the volumes in Table 7. Operating under the assumption that no net change in sediment volume should occur between the 11/15/2016 and 10/11/2016 survey measurements, the profile elevations of the 11/15/2016 were adjusted down approximately $7 \mathrm{~cm}$ (also see Section 6.3.4) such that the net change in volume is zero. The adjusted profiles were used to confirm the sediment migration between the two post-placement surveys. Note that this adjustment reasonably assumed that the ADCP survey offset is uniform across the survey area. However, if the survey bias were nonuniform across the survey area, then a uniform adjustment would negatively impact the results.

\subsection{Morphology change with the 11/15/2016 profile adjustment}

As stated previously, elevations of the 11/15/2016 were adjusted down approximately $7 \mathrm{~cm}$ such that the net change in volume is zero under the assumption that no net change in sediment volume should have occurred between the 11/15/2016 and 10/11/2016. No points were excluded from the analysis save those in which the elevation was not defined in one or more of the surveys. Figure 54 shows the elevation difference between the now-adjusted 11/15/2016 ADCP survey DEM (i.e., original 11/15/2016 survey elevations minus $7 \mathrm{~cm}$ ) and the 10/11/2016 DEM (held constant). Notice the increase in the erosive regions as compared to the original DEM difference in Figure 53 in which the study area was predominantly (and likely erroneously) accretionary between the two post-placement surveys. 
Figure 54. Elevation difference between the adjusted 11/15/2016 ADCP survey DEM and the 10/11/2016 ADCP survey DEM ( $\Delta \mathrm{z}=$ adjusted $11 / 15 / 2016 \mathrm{z}$ -

10/11/2016 z).

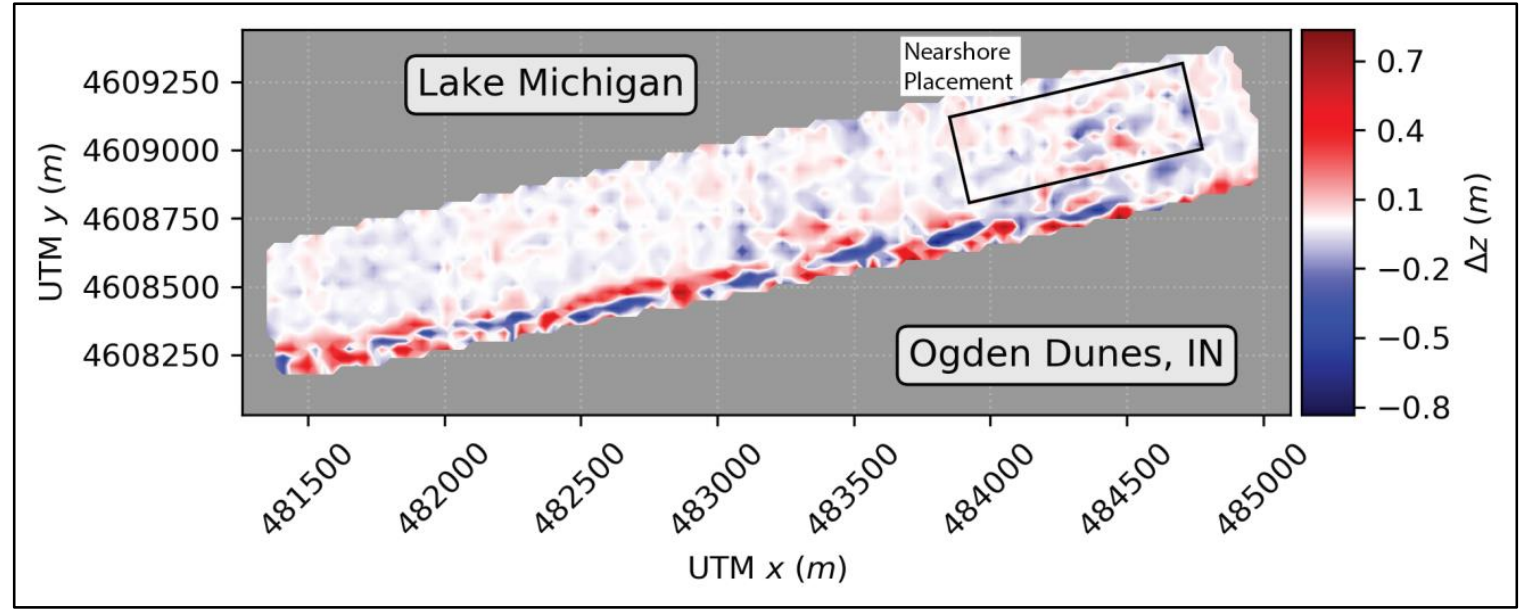

The volume and centroid calculations described in Section 7.3 were repeated to obtain the results shown in Table 8 , which shows these values calculated for each differenced surface (10/11/2016 - 06/02/2016 and adjusted 11/15/2016 - 06/02/2016), as well as the change between the two.

Table 8. Volume $(\mathrm{V})$ and the centroid location $\left(\mathrm{x}_{\mathrm{c}}, \mathrm{y}_{\mathrm{c}}\right)$ of each differenced surface $(10 / 11 / 2016-06 / 02 / 2016$ and adjusted $11 / 15 / 2016-06 / 02 / 2016)$, as well as the change between the two.

\begin{tabular}{|c|c|c|c|}
\hline Parameter & $\begin{array}{c}\text { 10/11/2016- } \\
06 / 02 / 2016\end{array}$ & $\begin{array}{c}\text { Adjusted 11/15/2016 } \\
-\end{array}$ & $\begin{array}{c}\text { Change } \\
11 / 15-10 / 11\end{array}$ \\
\hline $\mathrm{V}\left(\mathrm{m}^{3}\right)$ & $240,647( \pm 11,970)$ & $240,659( \pm 11,683)$ & 12 \\
\hline $\mathrm{x}_{\mathrm{c}}(\mathrm{m})$ & $360( \pm 8)$ & $343( \pm 7)$ & -17 \\
\hline $\mathrm{y}_{\mathrm{c}}(\mathrm{m})$ & $1505( \pm 55)$ & $1,486( \pm 53)$ & -19 \\
\hline
\end{tabular}

Similar to the unadjusted data presented in Table 7 , the change in the centroid of the sediment volume between the now-adjusted 11/15/2016 and the 10/11/2016 surveys (Table 8) indicated that the bulk of the sediment in the study area was located more onshore and farther to the east on 11/15/2016 relative to 10/11/2016 ( $\mathrm{x}_{\mathrm{c}}$ difference of $-17 \mathrm{~m}$ and $\mathrm{y}_{\mathrm{c}}$ difference of $-19 \mathrm{~m}$ ); however, the differences were not as dramatic as those from the unadjusted survey comparison ( $\mathrm{x}_{\mathrm{c}}$ difference of $-29 \mathrm{~m}$ and $\mathrm{y}_{\mathrm{c}}$ difference of $98 \mathrm{~m}$ in Table 7). Additionally, the alongshore direction of sediment migration for the adjusted survey comparison was to the east, rather than to the west as for the unadjusted survey comparison, although the magnitude of migration was less. 
As the 11/15/2016 survey was adjusted to conserve the total sediment volume in the region between the 10/11/2016 and 11/15/2016 surveys, a near-zero change in volume between the 10/11/2016 and the adjusted 11/15/2016 surveys (12 m3) was found. As shown in Table 9, when the volumes are broken down by region (i.e., the more offshore nearshore placement region $\left[\mathrm{V}_{\mathrm{x}>18 \mathrm{om}}\right]$ and more onshore sandbar region $\left[\mathrm{V}_{\mathrm{x}<18 \mathrm{om}}\right]$, it was observed that the nearshore placement region $[x>180 \mathrm{~m}]$ ) had lost $12,317 \mathrm{~m}^{3}$ of sediment between $10 / 11 / 2016$ and $11 / 15 / 2016$. However, this loss was balanced by the gain of a near-equal amount of sediment $\left(12,330 \mathrm{~m}^{3}\right)$ in the more onshore sandbar region $(x<180 \mathrm{~m})$.

Table 9. Volume (V) of each differenced surface (10/11/2016 - 06/02/2016 and adjusted $11 / 15 / 2016-06 / 02 / 2016)$ at $x<180 \mathrm{~m}$ and $\mathrm{x}>180$, as well as the difference between the two.

\begin{tabular}{|c|c|c|c|}
\hline Parameter & $\begin{array}{c}10 / 11 / 2016- \\
06 / 02 / 2016\end{array}$ & $\begin{array}{c}\text { Adjusted 11/15/2016 } \\
-\end{array}$ & $\begin{array}{c}\text { Change } \\
11 / 15-10 / 11\end{array}$ \\
\hline $\begin{array}{c}V_{x<180 m} \\
\left(m^{3}\right)\end{array}$ & $19,847( \pm 5,949)$ & $32,177( \pm 5,821)$ & 12,330 \\
\hline $\begin{array}{c}V_{x>180 m} \\
\left(m^{3}\right)\end{array}$ & $220,800( \pm 10,225)$ & $208,483( \pm 10,210)$ & $-12,317$ \\
\hline
\end{tabular}

The alongshore migration was critical to keep in mind when considering the results from analyzing individual profiles. It was difficult to obtain a clear picture of the overall sediment migration when considering the behavior of only the profiles that pass over the nearshore placement site. By way of explanation, Table 10 shows the volume per unit width $(\mathrm{V} / \mathrm{dy}-$ $\left.\mathrm{m}^{3} / \mathrm{m}\right)$ and the $\mathrm{x}$-centroid $\left(\mathrm{x}_{\mathrm{c}}\right)$ for each differenced profile (10/11/2016 06/02/2016 and adjusted 11/15/2016 - 06/02/2016) at the 19 profiles considered in this analysis. 
Table 10. Volume per unit width $\left(V / d y-m^{3} / m\right)$ and the $x$-centroid $\left(x_{c}\right)$ for each differenced profile (10/11/2016 - 06/02/2016 and adjusted 11/15/2016 06/02/2016) at all 19 profiles.

\begin{tabular}{|c|c|c|c|c|c|c|}
\hline Profile & $\begin{array}{c}\mathrm{V} / \mathrm{dy} \\
(10 / 11- \\
06 / 02)\end{array}$ & $\begin{array}{c}\text { V/dy (Adj. } \\
11 / 15- \\
06 / 02)\end{array}$ & $\begin{array}{c}\text { V/dy } \\
\text { Change } \\
\text { Adj. 11/15 } \\
\text { - 10/11 }\end{array}$ & $\begin{array}{l}x_{c}(10 / 11 \\
-06 / 02)\end{array}$ & $\begin{array}{c}x_{c} \text { (Adj. } \\
11 / 15- \\
06 / 02)\end{array}$ & $\begin{array}{c}x_{c} \text { Change } \\
11 / 15- \\
10 / 11\end{array}$ \\
\hline 1 & 10 & N/A & $\mathrm{N} / \mathrm{A}$ & 626 & $\mathrm{~N} / \mathrm{A}$ & $\mathrm{N} / \mathrm{A}$ \\
\hline 2 & 130 & 107 & -23 & 370 & 360 & -10 \\
\hline 3 & 153 & 142 & -11 & 376 & 387 & 9 \\
\hline 4 & 243 & 249 & 6 & 398 & 394 & -4 \\
\hline 5 & 256 & 246 & -10 & 399 & 397 & -2 \\
\hline 6 & 169 & 148 & -21 & 398 & 432 & 34 \\
\hline 7 & 103 & 88 & -15 & 345 & 383 & 38 \\
\hline 8 & 51 & 39 & -12 & 335 & 401 & 66 \\
\hline 9 & 14 & 48 & 34 & 523 & 228 & -295 \\
\hline 10 & 51 & 54 & 3 & 305 & 328 & 23 \\
\hline 11 & 43 & 23 & -20 & 436 & 564 & 128 \\
\hline 12 & 25 & 39 & 14 & 355 & 342 & -13 \\
\hline 13 & 54 & 53 & -1 & 353 & 334 & -19 \\
\hline 14 & 47 & 59 & 12 & 305 & 295 & -10 \\
\hline 15 & 46 & 44 & -2 & 349 & 313 & -36 \\
\hline 16 & 67 & 68 & 1 & 259 & 293 & 34 \\
\hline 17 & 90 & 71 & -19 & 293 & 281 & -12 \\
\hline 18 & 49 & 57 & 8 & 315 & 238 & -77 \\
\hline 19 & 48 & 60 & 12 & 362 & 278 & -84 \\
\hline
\end{tabular}

Several of the profiles located over the nearshore placement have centroids that were located farther offshore on 11/15/2016 than on 10/11/2016 (e.g., Profile $3-\Delta \mathrm{x}_{\mathrm{c}}=9 \mathrm{~m}$; Profile $6-\Delta \mathrm{x}_{\mathrm{c}}=34$; Profile $\left.7-\Delta \mathrm{x}_{\mathrm{c}}=38 \mathrm{~m}\right)$, which seemed to contradict the previous finding of the bulk migration of the volume centroid farther onshore. However, it was important to recall that the majority of the profiles over the nearshore placement were losing sediment from the 10/11/2016 to 11/15/2016 surveys (e.g., Profiles 3, 5, 6, and 7) - the only profile that gained sediment from 10/11/2016 to 11/15/2016 (Profile 4) had an onshore migration of the centroid. For the 
more westward profiles (those in the direction of the predominant alongshore sediment transport), it was observed that most of them gained sediment from 10/11/2016 to 11/15/2016 (Profiles 9, 10, 12, 14, 16, 18, and 19), and the sediment in each profile was located farther onshore (Profiles $9,12,13,14,15,17,18$, and 19). The difficulty of interpreting the results for an individual profile highlighted the need to consider the study area as a complete system (with substantial alongshore variation) rather than a collection of individual onshore/offshore migrations within each profile.

Before continuing, note that, whether the surveys were adjusted (Table 8) or not (Table 7), the bulk motion of sediment farther onshore was observed between the 10/11/2016 and 11/15/2016 surveys. The only difference was in the magnitude of the onshore motion (29 $\mathrm{m}$ onshore for unadjusted data, versus $17 \mathrm{~m}$ onshore for adjusted data). In addition, it was possible to estimate the effect of the survey adjustment on the placement region and sandbar region volumes shown in Table 9 by estimating the preferential change in volume observed in the unadjusted surveys over a uniform change in volume over the entire area. This was accomplished by comparing the observed volume changes in the placement region $(x>180 \mathrm{~m})$ and sandbar region $(x<180 \mathrm{~m})$ to the expected volume changes based on the ratio of the respective areas of the placement region and nearshore sandbar region $\left(A_{x<180}\right)$ relative to the total area of the surface (Ат) multiplied by the total volume change $\left(\mathrm{V}_{\mathrm{T}}\right)$

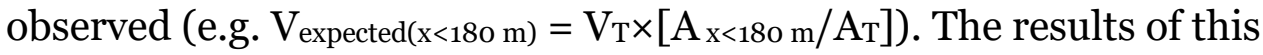
calculation are shown in Table 11.

Table 11. Expected vs. observed volume change in the sandbar region $(x<180 \mathrm{~m})$ and placement region $(x>180 \mathrm{~m}$ ) between the 10/11/2016 and 11/15/2016.

\begin{tabular}{|c|c|c|c|}
\hline Parameter & $\begin{array}{c}\text { Expected 11/15/2016 } \\
-10 / 11 / 2016\end{array}$ & $\begin{array}{c}\text { Observed 11/15/2016 } \\
-10 / 11 / 2016\end{array}$ & $\begin{array}{c}\text { Change } \\
11 / 15-10 / 11\end{array}$ \\
\hline $\begin{array}{c}V_{x<180 m} \\
\left(m^{3}\right)\end{array}$ & 32,705 & 45,901 & 13,196 \\
\hline $\begin{array}{c}V_{x>180 m} \\
\left(m^{3}\right)\end{array}$ & 102,104 & 88,908 & $-13,196$ \\
\hline
\end{tabular}

Note the similarities in the preferential volume change values $\left(13,196 \mathrm{~m}^{3}\right.$ for $x<180 \mathrm{~m}$ and $-13,196 \mathrm{~m}^{3}$ for $x>180 \mathrm{~m}$ ) in Table 11 to the change in sediment volume changes in the sandbar region $\left(12,330 \mathrm{~m}^{3}\right)$ and placement region $\left(-12,317 \mathrm{~m}^{3}\right)$ in Table 9. This indicated that the general trends of 
onshore sediment motion and the volumes of the onshore sediment migration were not substantially impacted by the survey adjustment.

\subsection{Comparison with SMT and CMS results}

The findings of morphology change presented in this section agreed well with the predicted sediment migration from the SMT and the CMS results. The SMT (Section 3) predicted sediment migration under both typical and storm wave conditions, although more onshore migration was predicted for typical wave conditions ( $91 \%$ ) than for storm conditions (72\%). The comparison of the volume change between the 10/11/2016 and 11/15/2016 surveys presented in Section 7.4 supported this assertion (i.e., the center of mass of the volume over the 06/02/2016 survey moved $17 \mathrm{~m}$ onshore from 10/11/2016 to 11/15/2016). The CMS modeling results indicated net erosion over the nearshore placement site (Area A3 in Figure 38) in the months following the placement, as observed in the analysis of the differences in the 10/11/2016 and 11/15/2016 adjusted survey data in Section 7.4 (Table 8). 


\section{Conclusions}

This study presented the results of a USACE evaluation of the placement and movement of material in the nearshore region of the beach at Ogden Dunes, Indiana. The objective of this evaluation was to improve the effectiveness of nearshore placement activities and ensure that nearshore placements are fulfilling their design purposes - passive nourishment and protection of the shoreline. Specifically, this report sought to observe and quantify the migration of the nearshore placement material in the months following placement. To determine this, the USACE undertook extensive monitoring from May to November 2016 before and after a planned $107,000 \mathrm{~m}^{3}$ nearshore placement that ended 7/15/2016. The monitoring involved copious data collection to measure the nearshore bathymetry and beach topography. This report specifically focused on morphology change between the 06/02/2016 pre-placement survey and two post-placement surveys (10/11/2016 and 11/15/2016) to determine the sediment migration in the months following the nearshore placement. The morphology change results were compared with prior predictions of the sediment migration from the SMT. The CMS suite of nearshore hydrodynamic and sediment transport models was also used to model the waves, currents, and morphology change in the vicinity over the nearshore placement monitoring duration.

The SMT was run on the historical wave conditions at the Ogden Dunes, Indiana, study site (grain size range of 0.1 to $0.3 \mathrm{~mm}$ ) to predict the migration of material placed in the nearshore. Under typical wave conditions, the SMT predicted that the median grain size would be mobilized by $37 \%-48 \%$ of the hourly significant waves and be transported onshore $91 \%$ of the time. For storm wave conditions, the SMT predicted the frequency of sediment mobility to be $76 \%-84 \%$ and $72 \%$ of the sediment migration was onshore.

The CMS was able to accurately model the waves, currents, water surface elevations, sediment transport, and morphology changes associated with the nearshore placement in this environment over the study duration. The model indicated that wind and waves are the predominant forcing mechanism in the nearshore region of Ogden Dunes, Indiana. These waves generated strong wave-driven currents in the surf zone at this site - 
currents were substantially weaker offshore. These currents dominated the modeled morphology change - the majority of the sediment migration in the nearshore was driven by strong westward alongshore currents. The validation to measured morphology indicated that CMS was able to calculate areas of bed volume changes and sediment migration in response to nearshore placement activities.

Direct analysis of the 06/02/2016, 10/11/2016, and 11/15/2016 survey data indicated that the bulk of the sediment in the study area was located more onshore on 11/15/2016 relative to 10/11/2016 (17 $\mathrm{m}$ farther onshore). The 11/15/2016 survey was adjusted to conserve sediment volume in the study area from 10/11/2016 to 11/15/2016. As stated previously, this adjustment was made under the assumption that no net change in sediment volume should occur between the 11/15/2016 and 10/11/2016. After breaking the sediment volumes down by region (i.e., the more offshore nearshore placement region and more onshore sandbar region, it was observed that the nearshore placement region lost 12,317 $\mathrm{m}^{3}$ of sediment between 10/11/2016 and 11/15/2016, and this loss was balanced by the gain of a near-equal amount $\left(12,330 \mathrm{~m}^{3}\right)$ of sediment in the more onshore nearshore sandbar region within the month spanning the two surveys.

It was reasonable to conclude from these results that over the study duration a considerable portion of the sediment placed in the nearshore remained in the study area and migrated farther onshore in between the 10/11/2016 and 11/15/2016 post-placement surveys. No discernable change in the beach topography was observed over the monitoring period, but the general trend of sediment motion in the nearshore region was towards the shoreline, and the duration of the monitoring was relatively brief. Unfortunately, though it was reasonable to assume that the shallower depths in the study area due to the nearshore placement will lead to decreased shoreline erosion due to greater wave dissipation over the placed material, the present study was not able to conclusively demonstrate this effect due to the loss of the more offshore wavemeasurement ADCP.

The USACE monitoring and analysis of this placement of dredged material in the nearshore and subsequent migration was a critical cog in the adaptive management strategy implemented by the RSM program and allowed the USACE and stakeholders to better understand and respond to 
the dynamic shoreline in the vicinity of the Town of Ogden Dunes, Indiana. The need to consider the entire study area as a complete system rather than discrete, independent processes also highlighted the importance of the high-level, systems-based approach to sediment management at region scales across multiple projects advocated for by the RSM Program. The results from this study will improve the USACE understanding of sediment migration following nearshore placement to support more sustainable shoreline management practices. 


\section{References}

Aquaveo. 2010. SMS: XY Series Files (*.xys). http://www.xmswiki.com/xms/SMS:XY_Series_Files_(*.xys)

Arnold, D. E., B. C. McFall, K. E. Brutsché, E. C. Maloney, and D. F. Bucaro. 2018. Nearshore Placement Techniques in Southern Lake Michigan. ERDC/CHL TR18-3. Vicksburg, MS: US Army Engineer Research and Development Center.

City of Gary, Indiana, Redevelopment Department. 2019. Residential District Codes. https://garyin.us/redevelopment/codes/

Duncker, J. J., J. Z. LeRoy, K. K. Johnson, J. A. Boldt, Z. W. Martin, and C. J. Bosch. 2017. Bathymetric and Hydrodynamic Surveys of Lake Michigan Nearshore near Ogden Dunes/Burns Harbor, Indiana. US Geological Survey data release. https://doi.org/10.5066/F7R49PQX

Esri. 2016. ArcGIS Desktop-Release 10.4. Redlands, CA: Environmental Systems Research Institute.

Larson, M., and N. C. Kraus. 1992. Analysis of Cross-shore Movement of Natural Longshore Bars and Material Placed to Create Longshore Bars. Technical Report DRP-92-5. Vicksburg, MS: US Army Engineer Waterways Experiment Station.

Lillycrop, L. S., J. W. McCormick, L. E. Parson, and M. A. Chasten, 2011. “Adaptive Management through Regional Sediment Management." Proceedings of the Western Dredging Association (WEDA XXXI) Technical Conference and Texas A\&M University (TAMU 42) Dredging Seminar, Nashville, TN, June 5-8.

Lin, L., Z. Demirbilek, and F. Yamada, 2008. CMS-Wave: A Nearshore Spectral Wave Processes Model for Coastal Inlets and Navigation Projects. ERDC/CHL TR-o813. Vicksburg, MS: US Army Engineer Research and Development Center.

McFall, B. C., S. J. Smith, C. E. Pollack, J. Rosati III, and K. E. Brutsché. 2016. Evaluating Sediment Mobility for Siting Nearshore Berms. ERDC/CHL CHETNIV-108. Vicksburg, MS: US Army Engineer Research and Development Center.

Morang, A., A. E. Frey, D. F. Bucaro, S. Brodzinsky, and J. A. Fuller. 2012. Sediment Budget for the Indiana Shore from Michigan City Harbor to Burns Waterway Harbor. ERDC/CHL TR-12-17. Vicksburg, MS: US Army Engineer Research and Development Center.

NOAA (National Oceanic and Atmospheric Administration), Center for Operational Oceanographic Products and Services. 2013. Tides and Currents. Calumet Harbor, Illinois - Station ID: 9087044. http://tidesandcurrents.noaa.gov/stationhome.html?id=9087044

NOAA, National Centers for Environmental Information. 2006. Bathymetric Data Viewer. Digital Elevation Model: Lake Michigan, USA. https://maps.ngdc.noaa.gov/viewers/bathymetry/?layers=dem 
NOAA. 2017. National Data Buoy Center (NDBC). Lake Michigan, USA - Station ID: 45007. https://www.ndbc.noaa.gov/

NOAA. 2018. Vertical Datum Transformation. https://vdatum.noaa.gov/

NPS (National Parks Service), Indiana Dunes National Park, Indiana. 2015. Nature \& Science. https://www.nps.gov/indu/learn/nature/index.htm

Parsons, D. R., P. R. Jackson, J. A. Czuba, F. L. Engel, B. L. Rhoads, K. A. Oberg, J. L. Best, D. S. Mueller, K. K. Johnson, and J. D. Riley. 2013. "Velocity Mapping Toolbox (VMT): A Processing and Visualization Suite for Moving-Vessel ADCP Measurements." Earth Surface Processes and Landforms 38(11): 1244-126o. doi:10.1002/esp.3367

Rosati, J. D., B. D. Carlson, J. E. Davis, and T. D. Smith. 2001. The Corps of Engineers National Regional Sediment Management Demonstration Program. ERDC/CHL CHETN-XIV-1. Vicksburg, MS: US Army Engineer Research and Development Center.

Sanchez, A., W. Wu, T. M. Beck, H. Li, J. Rosati III, R. Thomas, J. D. Rosati, Z. Demirbilek, M. Brown, and C. Reed. 2011a. Verification and Validation of the Coastal Modeling System, Report 3: Hydrodynamics. ERDC/CHL TR-11-10. Vicksburg, MS: US Army Engineer Research and Development Center.

Sanchez, A., W. Wu, T. M. Beck, H. Li, J. D. Rosati, Z. Demirbilek, and M. Brown. 2011b. Verification and Validation of the Coastal Modeling System, Report 4: Sediment Transport and Morphology Change. ERDC/CHL TR-11-10. Vicksburg, MS: US Army Engineer Research and Development Center.

Schrader, M. H., E. C. Douglass, and L. S. Lillycrop. 2016. Regional Sediment Management Strategies for the Vicinity of St. Augustine Inlet, St. Johns County, Florida. ERDC/CHL TR-16-12. Vicksburg, MS: US Army Engineer Research and Development Center.

Teledyne Marine Workhorse Rio Grande ADCP. 2013. Workhorse Rio Grande Datasheet. http://www.teledynemarine.com/rio-grande-adcp

Town of Ogden Dunes, Indiana Building Department. 2013. http://ogdendunes.in.gov/committees-and-departments/building-department

Tyler, Z. J., B. C. McFall, K. E. Brutsché, E. C. Maloney, and D. F. Bucaro. 2018. Physical Monitoring Modeling Methods for the Nearshore Placement of Dredged Sediment. ERDC/TN RSM-18-6. Vicksburg, MS: US Army Engineer Research and Development Center.

USACE LRC (US Army Corps of Engineers, Chicago District). 1995. Burns Small Boat Harbor Monitoring Program Portage County, Indiana. 3, 5, 10, and 30. Chicago, IL: USACE, Chicago District.

US Geological Survey (USGS). 2019. USGS 04095090 Portage-Burns Waterway at Portage, IN, in USGS water data for the Nation: US Geological Survey National Water Information System database, accessed August 29, 2019, at https://doi.org/10.5066/F7P55KJN [Site information directly accessible at https://waterdata.usgs.gov/nwis/inventory/?site_no=04095090\&agency_cd=USGS\&amp;] 
Wheaton, J. M., J. Brasington, S. E. Darby, and D. A. Sear. 2010. “Accounting for Uncertainty in DEMs from Repeat Topographic Surveys: Improved Sediment Budgets." Earth Surface Processes and Landforms 35(2): 136-156. doi: 10.1002/esp.1886 


\section{Appendix A: Grain Size Distribution Test Data}
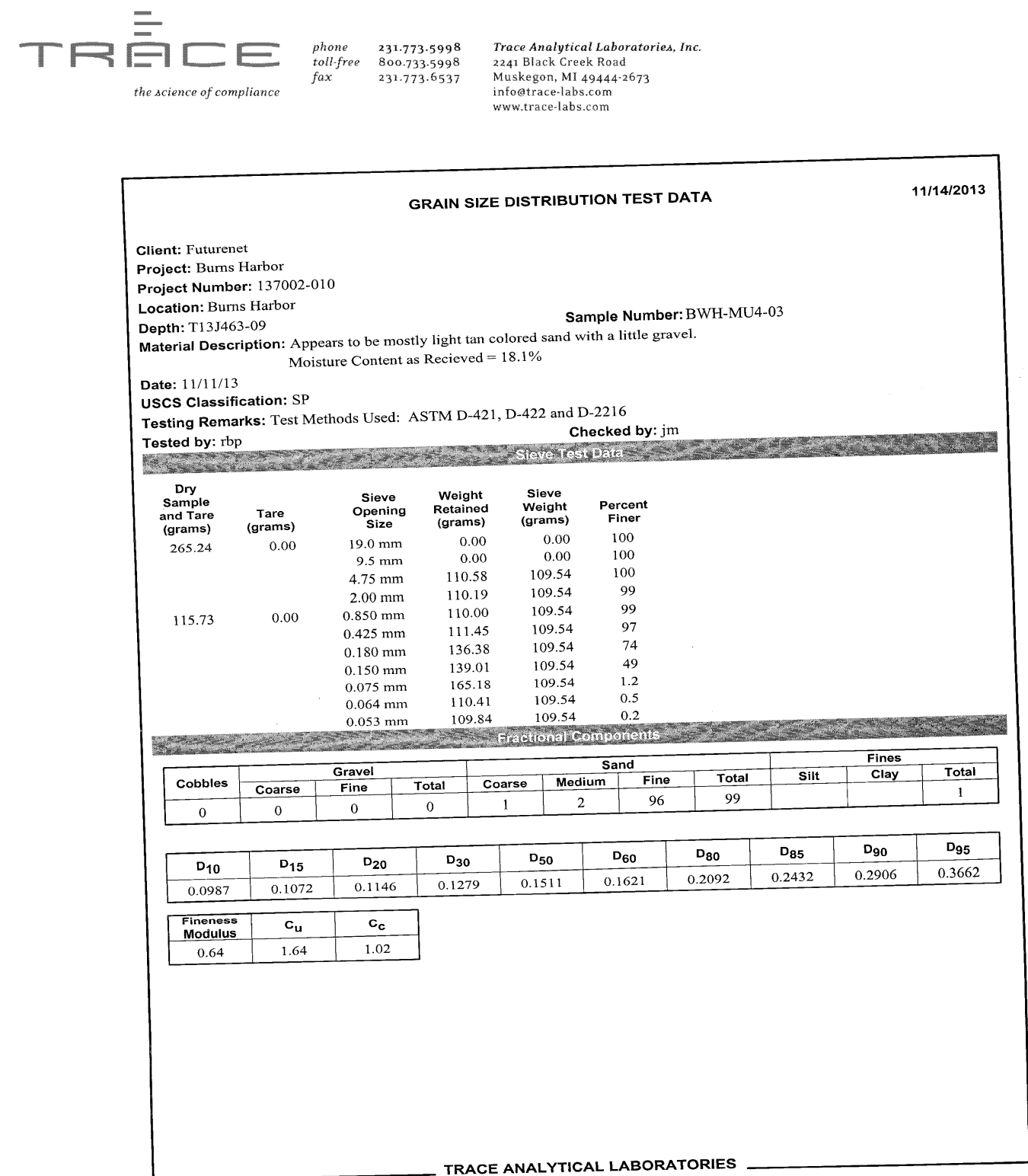

CERTIFICATE OF ANALYSIS

This report shall not be reproduced, except in full, without the written consent of Trace Analytical Laboratories, Inc. 

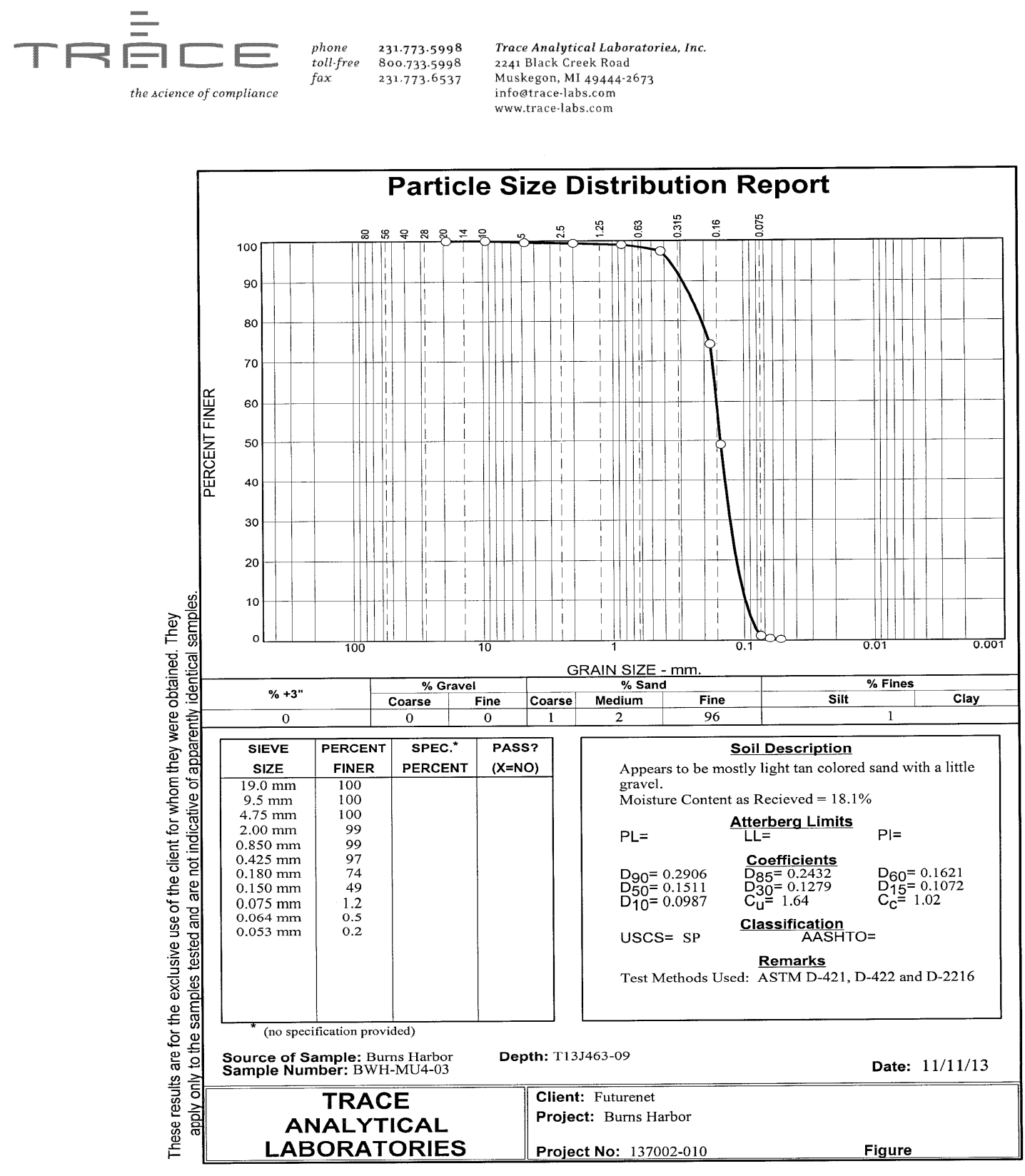

Tested By: rbp Checked By: jm 


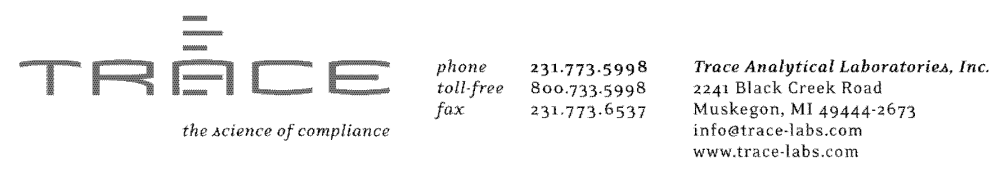

GRAIN SIZE DISTRIBUTION TEST DATA

$11 / 14 / 2013$

Client: Futurenet

Project: Burns Harbor

Project Number: 137002-010

Location: Burns Harbor

Depth: T13J463-10

Sample Number: BWH-MU4-01

Material Description: Appears to be mostly tan colored sand.

Date: $11 / 11 / 13$

USCS Classification: SP

Testing Remarks: Test Methods Used: ASTM D-421, D-422 and D-2216

Tested by: $r b p \quad$ Checked by: jm

Tested by: rbp

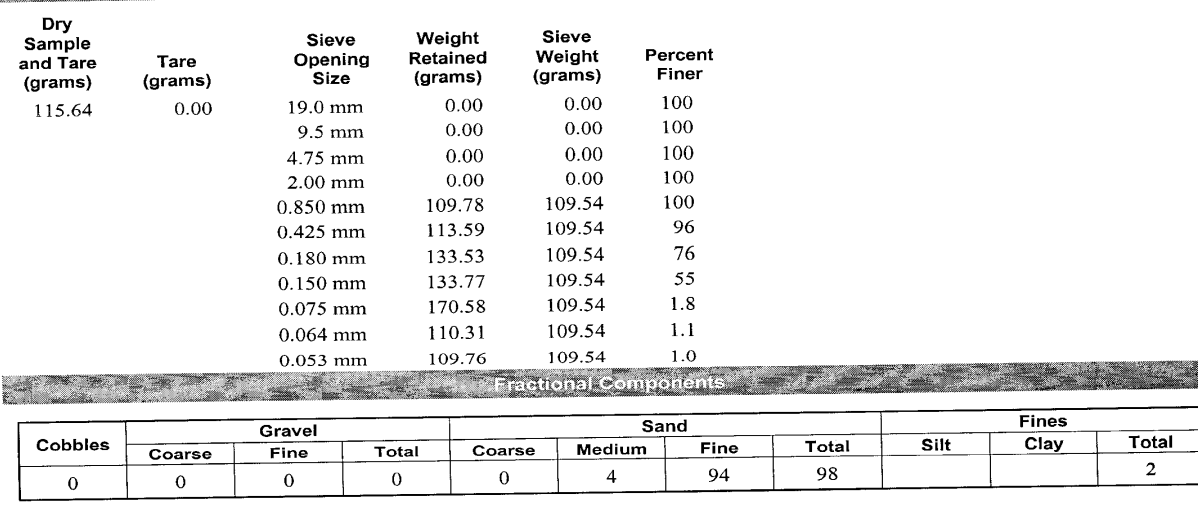

\begin{tabular}{|c|c|c|c|c|c|c|c|c|c|}
\hline $\mathbf{D}_{\mathbf{1 0}}$ & $\mathbf{D}_{\mathbf{1 5}}$ & $\mathbf{D}_{\mathbf{2 0}}$ & $\mathbf{D}_{\mathbf{3 0}}$ & $\mathbf{D}_{\mathbf{5 0}}$ & $\mathbf{D}_{\mathbf{6 0}}$ & $\mathbf{D}_{\mathbf{8 0}}$ & $\mathbf{D}_{\mathbf{8 5}}$ & $\mathbf{D}_{\mathbf{9 0}}$ & $\mathbf{D}_{\mathbf{9 5}}$ \\
\hline 0.0930 & 0.1004 & 0.1071 & 0.1197 & 0.1443 & 0.1569 & 0.2060 & 0.2443 & 0.2991 & 0.3892 \\
\hline
\end{tabular}

\begin{tabular}{|c|c|c|}
\hline $\begin{array}{c}\text { Fineness } \\
\text { Modulus }\end{array}$ & $\mathrm{c}_{\mathrm{u}}$ & $\mathrm{c}_{\mathrm{c}}$ \\
\hline 0.57 & 1.69 & 0.98 \\
\hline
\end{tabular}

TRACE ANALYTICAL LABORATORIES

CERTIFICATE OF ANALYSIS

This report shall not be reproduced, except in full, without the written consent of Trace Analytical Laboratories, Inc. 

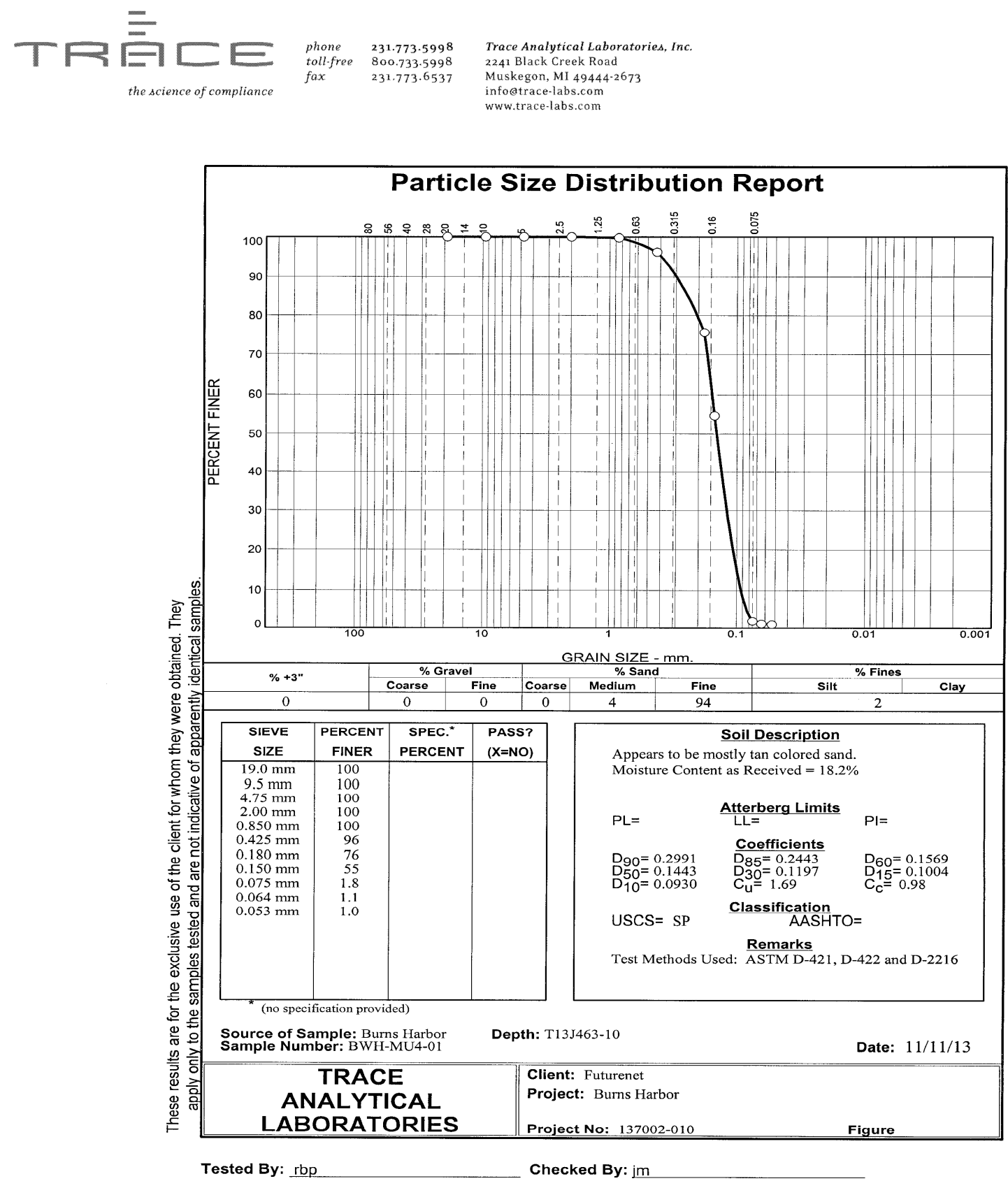

CERTIFICATE OF ANALYSIS

This report shall not be reproduced, except in full, without the written consent of Trace Analytical Laboratories, Inc. 


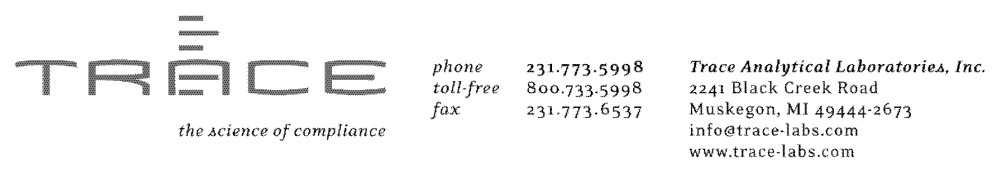

GRAIN SIZE DISTRIBUTION TEST DATA

$11 / 14 / 2013$

Client: Futurenet

Project: Burns Harbor

Project Number: 137002-010

Location: Burns Harbor

Depth: T13J463-11 Sample Number: BWH-MU4-02

Material Description: Appears to be mostly fine sand with some silt.

Date: $11 / 11 / 13$

Moisture Content as Received $=22.7 \%$

Testing Remarks: Test Methods Used: ASTM D-421, D-422 and D-2216

Tested by: rbp

Checked by: jm

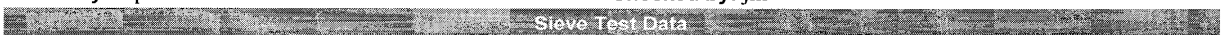

Dry

Sample Sieve Weight

and Tare Tare Opening Retained Weight Percent

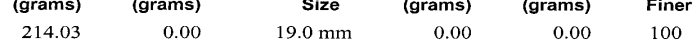

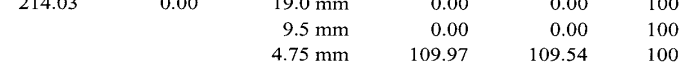

$\begin{array}{llll}4.75 \mathrm{~mm} & 109.97 & 109.54 & 100 \\ 2.00 \mathrm{~mm} & 109.54 & 109.54 & 100\end{array}$

$\begin{array}{rrrrrr}115.93 & 0.00 & 0.850 \mathrm{~mm} & 110.05 & 109.54 & 99\end{array}$

$\begin{array}{llllll}115.93 & 0.00 & 0.850 \mathrm{~mm} & 110.05 & 109.54 & 99 \\ & & 0.425 \mathrm{~mm} & 116.80 & 109.54 & 93\end{array}$

$\begin{array}{llll}0.425 \mathrm{~mm} & 116.80 & 109.54 & 93 \\ 0.180 \mathrm{~mm} & 143.29 & 109.54 & 64\end{array}$

$\begin{array}{llll}0.150 \mathrm{~mm} & 125.50 & 109.54 & 50 \\ 0.075 \mathrm{~mm} & 150.15 & 109.54 & 15\end{array}$

$\begin{array}{rrrr}0.064 \mathrm{~mm} & 113.54 & 109.54 & 12\end{array}$

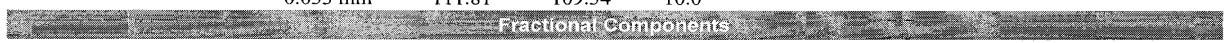

\begin{tabular}{|c|c|c|c|c|c|c|c|c|c|c|}
\hline \multirow{2}{*}{ Cobbles } & \multicolumn{9}{|c|}{ Gravel } & \multicolumn{3}{c|}{ Sand } & \multicolumn{3}{c|}{ Fines } \\
\cline { 2 - 11 } & Coarse & Fine & Total & Coarse & Medium & Fine & Total & Silt & Clay & Total \\
\hline 0 & 0 & 0 & 0 & 0 & 7 & 78 & 85 & & & 15 \\
\hline
\end{tabular}

\begin{tabular}{|c|c|c|c|c|c|c|c|c|c|}
\hline $\mathbf{D}_{\mathbf{1 0}}$ & $\mathbf{D}_{\mathbf{1 5}}$ & $\mathbf{D}_{\mathbf{2 0}}$ & $\mathbf{D}_{\mathbf{3 0}}$ & $\mathbf{D}_{\mathbf{5 0}}$ & $\mathbf{D}_{\mathbf{6 0}}$ & $\mathbf{D}_{\mathbf{8 0}}$ & $\mathbf{D}_{\mathbf{8 5}}$ & $\mathbf{D}_{\mathbf{9 0}}$ & $\mathbf{D}_{\mathbf{9 5}}$ \\
\hline 0.0533 & 0.0740 & 0.0867 & 0.1087 & 0.1494 & 0.1703 & 0.2416 & $\mathbf{0 . 2 7 9 5}$ & 0.3467 & 0.4949 \\
\hline
\end{tabular}

\begin{tabular}{|c|c|c|}
\hline $\begin{array}{c}\text { Fineness } \\
\text { Modulus }\end{array}$ & $\mathbf{c}_{\mathbf{u}}$ & $\mathbf{c}_{\mathbf{c}}$ \\
\hline 0.67 & 3.20 & 1.30 \\
\hline
\end{tabular}

TRACE ANALYTICAL LABORATORIES

CERTIFICATE OF ANALYSIS

This report shall not be reproduced, except in full, without the written consent of Trace Analytical Laboratories, Inc. 

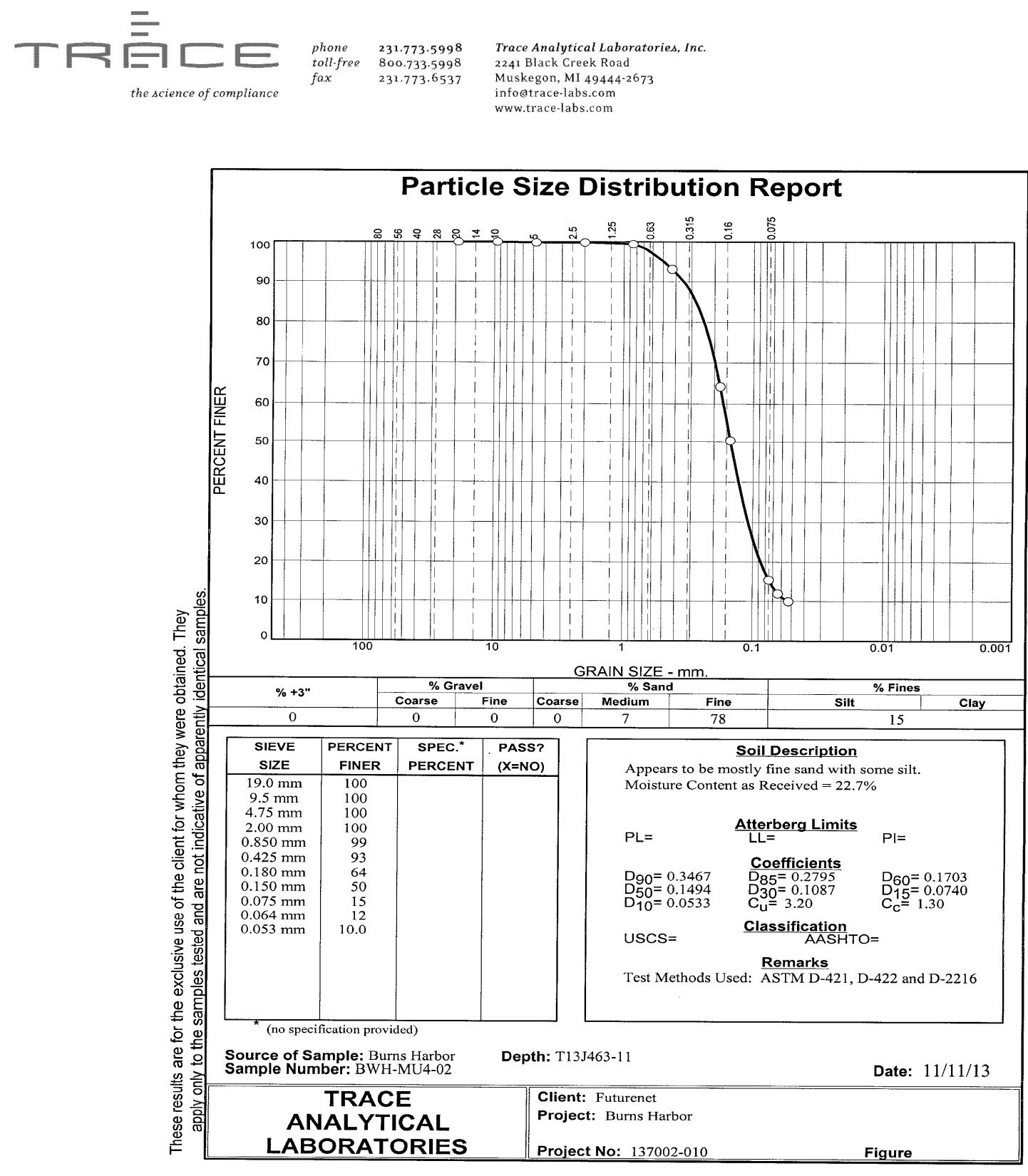

Tested By: rbp

Checked By: im

CERTIFICATE OF ANALYSIS

This report shall not be reproduced, except in full, without the written consent of Trace Analytical Laboratories, Inc. 

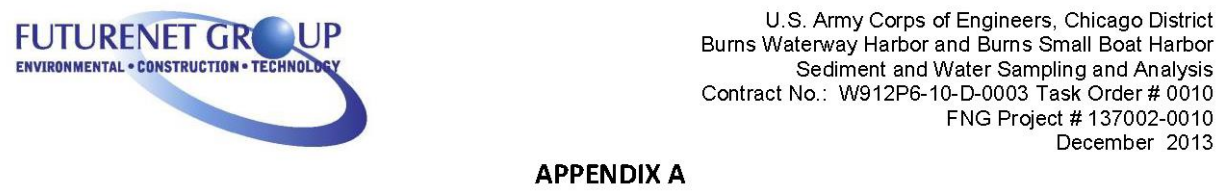

Figure 6 - Dredge Management Units

Burns Waterway Harbor Project Map

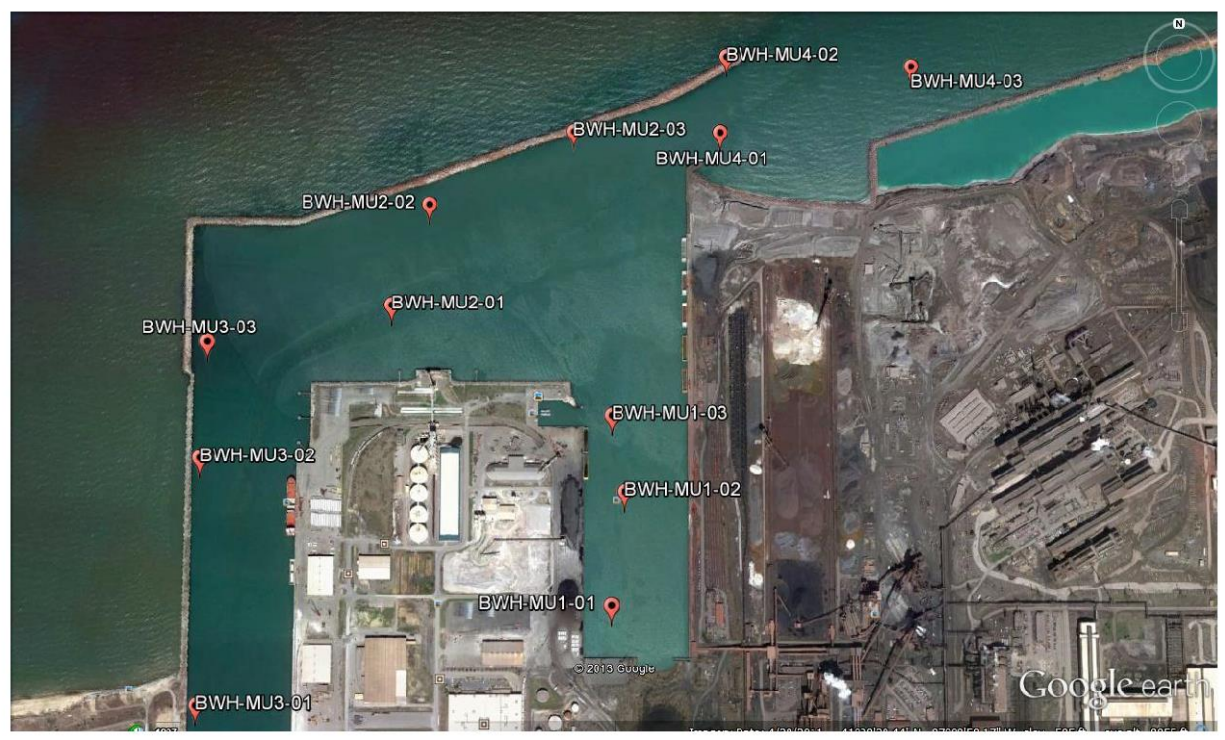




\section{Appendix B: Configuration File for ADCP Deployment}

\section{Burns Harbor/Ogden Dunes Shallow water deployment: TRDI- ADCP configuration file: BHSH1}

\author{
Shallow ADCP configuration file: CR1 \\ CF11101 \\ EA0 \\ EB0 \\ ED50 \\ ES0 \\ EX11111 \\ EZ1111101 \\ WA255 \\ WB0 \\ WD111100000 \\ WF44 \\ WN30 \\ WP10 \\ WS25 \\ WV175 \\ HD111000000 \\ HB5 \\ HP1200 \\ HR01:00:00.00 \\ HT00:00:00.50 \\ TE00:30:00.00 \\ TP03:00.00 \\ TF16/06/02 12:00:00 \\ CK \\ CS \\ ; \\ ;Instrument $=$ Workhorse Sentinel \\ ;Frequency $=1228800$ \\ ; Water Profile $=$ YES \\ ;Bottom Track $=\mathrm{NO}$ \\ ;High Res. Modes $=\mathrm{NO}$ \\ ;High Rate Pinging $=\mathrm{NO}$
}

;Shallow Bottom Mode $=\mathrm{NO}$

; Wave Gauge $=$ YES

;Lowered ADCP $=\mathrm{NO}$

;Ice Track $=\mathrm{NO}$

;Surface Track $=\mathrm{NO}$

;Beam angle $=20$

; Temperature $=15.00$

;Deployment hours $=1920.00$

;Battery packs $=1$

;Automatic TP = YES

;Memory size $[\mathrm{MB}]=4000$

;Saved Screen $=1$

;

;Consequences generated by PlanADCP

Version 2.06:

;First cell range $=0.80 \mathrm{~m}$

; Last cell range $=8.05 \mathrm{~m}$

;Max range $=21.93 \mathrm{~m}$

;Standard deviation $=4.31 \mathrm{~cm} / \mathrm{s}$

;Ensemble size $=754$ bytes

;Storage required $=174.29 \mathrm{MB}$

(182760961 bytes)

;Power usage $=430.00 \mathrm{Wh}$

;Battery usage $=1.0$

;Samples / Wv Burst $=1200$

;Min NonDir Wave Per $=1.67 \mathrm{~s}$

;Min Dir Wave Period $=1.76 \mathrm{~s}$

;Bytes $/$ Wave Burst $=93680$

;

; WARNINGS AND CAUTIONS:

; Waves Gauge feature has to be installed in Workhorse to use selected option.

; Advanced settings have been changed. 


\title{
Burns Harbor/Ogden Dunes Deep water deployment: TRDI- ADCP configuration file: BHDP2
}

\author{
CR1 \\ CF11101 \\ EA0 \\ EB0 \\ ED100 \\ ES0 \\ EX11111 \\ EZ1111101 \\ WA255 \\ WB0 \\ WD111100000 \\ WF44 \\ WN40 \\ WP15 \\ WS35 \\ WV175 \\ HD111000000 \\ HB5 \\ HP1200 \\ HR01:00:00.00 \\ HT00:00:00.50 \\ TE00:20:00.00 \\ TP01:20.00 \\ TF16/06/02 12:00:00 \\ CK \\ CS \\ ; \\ ;Instrument $=$ Workhorse Sentinel \\ ;Frequency $=1228800$ \\ ; Water Profile $=$ YES \\ ;Bottom Track $=\mathrm{NO}$ \\ ;High Res. Modes = NO \\ ;High Rate Pinging $=\mathrm{NO}$ \\ ;Shallow Bottom Mode= NO \\ ; Wave Gauge $=$ YES \\ ;Lowered ADCP = NO \\ ; Ice Track $=\mathrm{NO}$ \\ ;Surface Track = NO \\ ;Beam angle $=20$ \\ ;Temperature $=15.00$ \\ ;Deployment hours $=1800.00$ \\ ;Battery packs $=1$ \\ ;Automatic TP = YES \\ ;Memory size $[\mathrm{MB}]=4000$
}




\section{Study Area boundary points}

\begin{tabular}{|l|l|l|}
\hline point & northing & easting \\
\hline DA01 & 2323798 & 2920288 \\
\hline DA02 & 2324877 & 2920042 \\
\hline DA03 & 2326170 & 2925570 \\
\hline DA04 & 2325082 & 2925810 \\
\hline
\end{tabular}

\section{ADCP coordinates}

nearshore V-ADCP (BHDP 2) $\quad 41^{\circ} 37^{\prime} 44.90^{\circ} \mathrm{N}, 87^{\circ} 12^{\prime} 06.90^{\circ} \mathrm{W}$ offshore V-ADCP (BHDP 1) $41^{\circ} 37^{\prime} 56.57^{\circ} \mathrm{N}, 87^{\circ} 12^{\prime} 10.18^{\circ} \mathrm{W}$ 


\section{Unit Conversion Factors}

\begin{tabular}{|l|c|l|}
\hline Multiply & By & To Obtain \\
\hline cubic feet & 0.02831685 & cubic meters \\
\hline cubic yards & 0.7645549 & cubic meters \\
\hline degrees Fahrenheit & $($ F-32)/1.8 & degrees Celsius \\
\hline feet & 0.3048 & meters \\
\hline inches & 0.0254 & meters \\
\hline knots & 0.5144444 & meters per second \\
\hline miles (US statute) & $1,609.347$ & meters \\
\hline miles per hour & 0.44704 & meters per second \\
\hline yards & 0.9144 & meters \\
\hline
\end{tabular}




\section{Acronyms and Abbreviations}

$\begin{array}{ll}\text { 2-D } & \text { two-dimensional } \\ \text { ADCP } & \text { acoustic Doppler current profiler } \\ \text { CMS } & \text { Coastal Modeling System } \\ \text { DEM } & \text { digital elevation model } \\ \text { GCD } & \text { Geomorphic Change Detection } \\ \text { GMT } & \text { Greenwich Mean Time } \\ \text { GPS } & \text { Global Positioning System } \\ \text { Hz } & \text { hertz } \\ \text { INS } & \text { Inertial Navigation System } \\ \text { kHz } & \text { kilohertz } \\ \text { km } & \text { kilometer } \\ \text { m } & \text { meter } \\ \text { m/s } & \text { meter per second } \\ \text { m3 } & \text { cubic meter } \\ \text { MBES } & \text { multibeam echosounder } \\ \text { mm } & \text { millimeter } \\ \text { NAVD88 } & \text { North American Vertical Datum of 1988 } \\ \text { NIPSCO } & \text { Northern Indiana Public Service Company } \\ \text { NOAA } & \text { National Oceanic and Atmospheric Administration } \\ \text { NPS } & \text { National Park Service } \\ \text { NRMSE } & \text { Normalized Root-Mean-Square-Error } \\ \text { RMSE } & \text { Root-Mean-Square-Error } \\ \text { RSM } & \text { Regional Sediment Management } \\ \text { RTK-dGPS } & \text { Real Time Kinematic differential Global Positioning System } \\ \text { SMT } & \text { Sediment Mobility Tool } \\ \text { TRDI } & \text { Teledyne-RD Instrument } \\ & \end{array}$




$\begin{array}{ll}\text { USACE } & \text { US Army Corps of Engineers } \\ \text { USGS } & \text { US Geological Survey } \\ \text { USGS-INKY } & \text { US Geological Survey, Indiana-Kentucky Water Science Center } \\ \text { UTM } & \text { Universal Transverse Mercator } \\ \text { VMT } & \text { Velocity Mapping Toolbox } \\ \text { WIS } & \text { Wave Information Study }\end{array}$




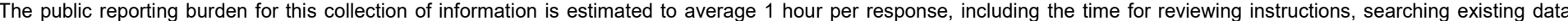

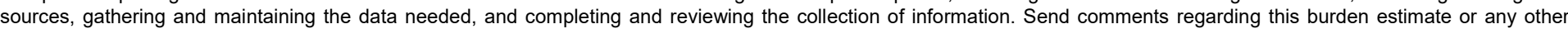

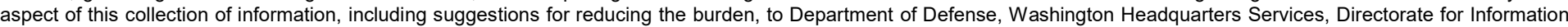

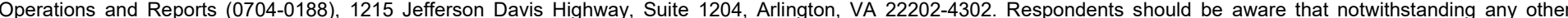
provision of law, no person shall be subject to any penalty for failing to comply with a collection of information if it does not display a currently valid OMB control number. PLEASE DO NOT RETURN YOUR FORM TO THE ABOVE ADDRESS.

\begin{tabular}{l|l|l}
$\begin{array}{l}\text { 1. REPORT DATE } \\
\text { March } 2020\end{array}$ & $\begin{array}{l}\text { 2. REPORT TYPE } \\
\text { Final Report }\end{array}$ & 3. DATES COVERED (FrOm - To)
\end{tabular}

\section{TITLE AND SUBTITLE}

Analysis of Nearshore Placement of Sediments at Ogden Dunes, Indiana 5a. CONTRACT NUMBER

5b. GRANT NUMBER

5c. PROGRAM ELEMENT NUMBER

5d. PROJECT NUMBER

6. AUTHOR(S)

David L. Young, Katherine E. Brutsché, Honghai Li, Brian C. McFall, Erin C. Maloney, Kaitlyn E. McClain, David F. Bucaro, Jessica Z. LeRoy, James J. Duncker, Kevin K. Johnson, and P. Ryan Jackson

5e. TASK NUMBER

5f. WORK UNIT NUMBER

7. PERFORMING ORGANIZATION NAME(S) AND ADDRESS(ES) (see reverse)

\section{PERFORMING ORGANIZATION REPORT NUMBER}

ERDC/CHL TR-20-4

10. SPONSOR/MONITOR'S ACRONYM(S) USACE RSM

US Army Corps of Engineers, Chicago District Chicago, IL 60604

\section{NAME(S) AND ADDRESS(ES)}

US Army Corps of Engineers, Regional

Sediment Management Program

Vicksburg, MS 39180

12. DISTRIBUTION/AVAILABILITY STATEMENT

Approved for public release; distribution is unlimited.

\section{SUPPLEMENTARY NOTES}

Funding Account Code U4362913; AMSCO Code 008303

\section{ABSTRACT}

The harbor structures/shoreline armoring on the southern Lake Michigan shoreline interrupt sand migration. Ogden Dunes, Indiana, and the nearby Indiana Dunes National Lakeshore observed shoreline erosion due to engineered structures associated with Burns Waterway Harbor (east of Ogden Dunes) impeding natural east-to-west sediment migration. To remedy this, USACE placed over 450,000 cubic meters (m3) of dredged material post-2006 in the nearshore of Ogden Dunes. However, the effectiveness of nearshore placements for shoreline protection and littoral nourishment is not fully established. To improve nearshore placement effectiveness, USACE monitored the June/July 2016 placement and subsequent movement of 107,000 m3 of dredged material in the nearshore region at Ogden Dunes. This involved an extensive monitoring scheme (three bathymetry surveys, and two acoustic Doppler current profiler deployments), a Coastal Modeling System (CMS) numerical model of the changes following placement, and a prediction of sediment transport direction using the Sediment Mobility Tool (SMT). The SMT-predicted sediment migration direction was compared to observations. Observations indicated that between 10/11/2016 and 11/15/2016 the centroid of the sediment above the pre-placement survey moved $17 \mathrm{~m}$ onshore. These observations agreed with SMT predictions - onshore migration under storm and typical wave conditions. CMS accurately reproduced the hydrodynamic features.

\section{SUBJECT TERMS}

Dredging, Dredging spoil, Environmental management, Hydrodynamics, Ogden dunes (Ind.), Sedimentation and deposition, Sediment transport, Shorelines

\section{SECURITY CLASSIFICATION OF:}

\begin{tabular}{|l|c|l|}
\hline a. REPORT & b. ABSTRACT & c. THIS PAGE \\
Unclassified & Unclassified & Unclassified \\
\hline
\end{tabular}

17. LIMITATION OF ABSTRACT

SAR
18. NUMBER 19a. NAME OF RESPONSIBLE PERSON

OF PAGES

98 David L. Young

19b. TELEPHONE NUMBER (Include area code) 252-261-6840; Ext. 265 


\section{PERFORMING ORGANIZATION NAME(S) AND ADDRESS(ES) (continued)}

Coastal and Hydraulics Laboratory

US Army Engineer Research and Development Center 3909 Halls Ferry Rd.

Vicksburg, MS 39180-6199

US Army Corps of Engineers, Chicago District.

231 LaSalle Street, Suite 1500

Chicago, Illinois 60604

US Geological Survey

Central Midwest Water Science Center

405 N. Goodwin Ave.

Urbana, Illinois 61801 